\title{
Systematic Categorization of Optimization Strategies for Virtual Power Plants
}

\author{
Amit Kumer Podder ${ }^{1}\left(\mathbb{D}\right.$, Sayemul Islam ${ }^{1} \mathbb{D}$, Nallapaneni Manoj Kumar 2,*(D), \\ Aneesh A. Chand ${ }^{3, * \mathbb{D}}$, Pulivarthi Nageswara Rao ${ }^{4}$, Kushal A. Prasad ${ }^{3}$, T. Logeswaran 5 \\ and Kabir A. Mamun ${ }^{3}$ (D) \\ 1 Department of Electrical and Electronic Engineering, Khulna University of Engineering \& Technology, \\ Khulna 9203, Bangladesh; amit@eee.kuet.ac.bd (A.K.P.); sayemul100@gmail.com (S.I.) \\ 2 School of Energy and Environment, City University of Hong Kong, Kowloon, Hong Kong \\ 3 School of Engineering and Physics, The University of the South Pacific, Suva, Fiji; \\ kushalaniketp@gmail.com (K.A.P.); kabir.mamun@usp.ac.fj (K.A.M.) \\ 4 Department of Electrical Electronics and Communication Engineering, Gandhi Institute of Technology and \\ Management (Deemed to be University), Visakhapatnam 530045, Andhra Pradesh, India; \\ dr.nageshpulivarthi@gmail.com \\ 5 Department of Electrical and Electronics Engineering, Kongu Engineering College, Perundurai, \\ Erode 638060, Tamil Nadu, India; logeskongu@gmail.com \\ * Correspondence: mnallapan2-c@my.cityu.edu.hk (N.M.K.); aneeshamitesh@gmail.com (A.A.C.)
}

Received: 14 October 2020; Accepted: 25 November 2020; Published: 27 November 2020

check for updates

\begin{abstract}
Due to the rapid growth in power consumption of domestic and industrial appliances, distributed energy generation units face difficulties in supplying power efficiently. The integration of distributed energy resources (DERs) and energy storage systems (ESSs) provides a solution to these problems using appropriate management schemes to achieve optimal operation. Furthermore, to lessen the uncertainties of distributed energy management systems, a decentralized energy management system named virtual power plant (VPP) plays a significant role. This paper presents a comprehensive review of 65 existing different VPP optimization models, techniques, and algorithms based on their system configuration, parameters, and control schemes. Moreover, the paper categorizes the discussed optimization techniques into seven different types, namely conventional technique, offering model, intelligent technique, price-based unit commitment (PBUC) model, optimal bidding, stochastic technique, and linear programming, to underline the commercial and technical efficacy of VPP at day-ahead scheduling at the electricity market. The uncertainties of market prices, load demand, and power distribution in the VPP system are mentioned and analyzed to maximize the system profits with minimum cost. The outcome of the systematic categorization is believed to be a base for future endeavors in the field of VPP development.
\end{abstract}

Keywords: virtual power plants; digital electricity; optimization strategies; distributed energy resources; renewable energy resources; energy management; energy scheduling; distributed generation; real-time energy markets; electricity market; demand response; optimization in virtual power plants; price-based unit commitment model; intelligent technique in power management; day-ahead scheduling

\section{Introduction}

The increasing demand for power in the electricity market and adverse effects in the environment introduce distributed energy resources (DERs) as the alternative to the conventional power generation system. The traditional generation of power uses fossil fuels (oil, gas), which emit toxic gases and affect the environment. Conventionally, generation units focus on only the 'connection' concept to the transmission system to distribute power to the energy market. The conventional generation 
term is replaced by the virtual power plant (VPP) concept, which integrates DERs rather than making connections [1-3]. The idea of VPP was first proposed in 1997 by Shimon Awerbuch that integrates DERs to ensure efficient power distribution with minimum cost [4]. Distributed generation (DG) units are usually found near the distribution networks with some characteristics such as decentralization, small generation units, etc. DERs include both the generation units as well as energy storage units [5]. Two types of DG are available such as renewable energy resources (RERs) and fuel-based energy resources. RERs present photovoltaic (PV), wind power plants, and so on, whereas fuel-based energy represents micro-turbine, fuel cell, and internal combustion engine generator as the generation units. Several distribution networks are implemented in recent times with DERs, including long-term and short-term operations [6-12]. To cope with the massive electricity demand, DERs operation seems to be quite tricky. Hence, a reliable solution should be implemented to overcome these difficulties and uncertainties. VPP acts as a sustainable solution for the optimal operation of DERs and smooth power distribution to the loads. VPP presents a platform to aggregate all the DERs that promote system visibility and governance of the power management system and ensure better interactions among the system's different components. VPP proposes a decentralized platform and energy-efficient management scheme for DERs [13]. VPP considers environmental effect, commercial efficacy, and day-ahead scheduling for optimal operation of DERs and fulfills load demand. VPP emphasizes more on eliminating uncertainties that arise due to market prices, load demand, and power distribution networks.

VPPs are of two kinds: commercial VPP (CVPP) and technical VPP (TVPP). CVPP focuses on the power system's economic aspects to minimize system cost with the highest profits. It considers present load demand in the electricity market and uses appropriate methods to determine the future load demand. It also observes the probable risk conditions and imbalances in the system. On the other hand, TVPP collects different information from CVPP, such as DERs maximum capacity, future load demand, and so on, to take the proper steps for VPP. TVPP computes data of different parameters of DERs to observe the system efficacy.

Active control between DERs and flexible loads in VPP, considering economic, technical, and environmental aspects, is demonstrated in [14]. The paper intends to efficiently integrate generation units to smart grids and maintain voltage, load management, and short-circuit protection. Germany considers the VPP as an alternative energy system [15]. This paper analyzes different aspects of VPP and explores the potential feasibility of using VPP with modern technology. The intelligent control and the integrated computer system are utilized to reduce greenhouse gases [16]. Hence, Fuzzy logic control (FLC) is adopted to achieve high-level feasibility. The optimal operation can be attained by addressing the intelligent concept of VPP. Nikonowicz et al. [17] presents a comprehensive analysis of different VPP concepts depending on several aspects such as infrastructure, control scheme, and verification platform. It provides a correlative idea to characterize them in terms of economic and technical efficacy. OpenADR 2.0b communication protocol contributes to developing a secure and reliable VPP system [18]. An Internet-based communication system facilitates the transmission system operator (TSO), and numeric simulation verifies different operating conditions of VPP. Mahmud et al. [19] introduces the 'Internet of Energy (IoE)' concept that aggregates DERs and flexible loads. This paper analyzes the IoE concepts and compares them with the conventional control scheme to justify the reliability. The relative analysis includes the VPP structure, control system, economic and technical feasibility. However, this concept cannot provide a solution to remove uncertainties, economic dispatch, and communication delay.

Software integration with VPP is developed in [20] that provides information and communication technology (ICT) based control for DERs to loads and facilitates electric vehicle (EV) charging purposes. A comparative review of different VPP is provided in [21] based on optimization feasibility, technical and economic aspects, security, data, and intelligent management platform. The European FENIX project for VPP is presented in [22] that analyzes each CVPP depending on marginal cost, computed data, and forecasting data. Integration between distribution system operator (DSO) and transmission system 
operator (TSO) is also established. Furthermore, a VPP system is proposed in [23] to satisfy the emergency power demand in South Korea that integrates different generation units. The proposed scheme considers only economic feasibility: to maximize the profits at a low cost. California test method is employed to verify financial reliability. However, the scheme does not consider the technical and environmental benefits. A comparative analysis of the business model (BM) for VPP in different countries (American, German, Australian, Danish, and Finnish) are introduced in [24] that presents several unique characteristics of each countries BM. The generated energy is distributed in the electricity market, and distributors need to follow the rules and regulations to sustain the electricity market's economic benefits. For this purpose, different BM policies have been established. This paper also reviews the business model of Poland based on economic and political aspects.

The potentiality of combined heat and power (CHP) can be utilized with VPP to generate more power and fulfill the power demands [25]. It analyzes the amount of power and gas consumption and presents a BM to optimally operate and distribute power in the energy market based on the technical aspects. Generic VPP based on service-oriented architecture (SOA) is demonstrated in [26] where software and communication-based technology is employed to attain the technical feasibility and environmental benefits and distribute power to the consumers at a low cost. An analysis of VPP is presented in [27] based on the technical aspects that provide an efficient power distribution among the generation and grids. The study determines the real-time values of the different parameters in the power distribution system. It formulates a notion about the number of DERs and ESS that can be optimally connected to VPP based on the technical and economic aspects. A detailed analysis of uncertainties in VPP is carried out in [28] that is mainly based on three factors: renewable power, load demand, and market price. A comprehensive analysis of the three aspects of uncertainties is presented, and the process of lessening the uncertainties is demonstrated. Etherden et al. [29] shows the common information model (CIM) power utility standard and supervisory control and data acquisition (SCADA) to fulfill the communication and functional requirements for VPP. A relative analysis of different VPP based on flexible loads, generation units, distribution factors is presented in [30]. Moreover, they also provided a detailed analysis of technical VPP and commercial VPP. The possibility of optimal CHP integration with VPP and demand response in the electricity market is also discussed. An intelligent identification and fault diagnosis in a large-scale power plant is proposed in [31], based on a multi-agent system (MAS). The MAS concept can be adapted to the VPP system to achieve efficient power distribution and intelligent identification. A $\mu-\mathrm{CHP}$ unit acts as an alternative source in VPP during the large power demand [32]. A comprehensive analysis of hierarchical system with VPP regarding control, market policies, and storage capabilities are presented in [33]. Also, they discuss different control strategies based on communication and intelligent governance for the smart grid with storage capability. However, the authors in Ref [33] does not provide any BM idea to develop economic competence in the electricity market. Pal et al. [34] presents a comparative analysis of different optimization schemes and the best optimization scheme is chosen based on different aspects: VPP sizing, costing, environmental feasibility, transmission loss, and uncertainties.

Based on the above-carried literature review, it is realized that each literature focuses on analyzing the VPP operation in terms of technical and economic efficacy. However, this literature does not provide any classification for VPP optimization techniques to perceive the comprehensive analysis of VPP techniques. Some of them fail to present an appropriate BM to handle electricity market demand response. There is a lack of proper forecasting approach in a case that flinches to compute the adequate forecasted values for the demand responses. To compensate for the deficiencies mentioned above, a brief analysis of 65 existing VPP optimization techniques is introduced in this paper. A classification for these existing techniques based on system configuration, parameters, and control scheme is established. Objective functions and uncertainties for each of the control schemes are also explored.

This paper is methodized into six sections. Section 1 includes the introductory talks that present a literature review and comparative analysis of VPP and demonstrates the paper's contribution. The overall information flow of the paper and critical contributions are presented in Section 2. 
A methodology that reviews existing literature is presented in Section 3. Section 4 presents the familiarization of VPP, CVPP, TVPP, objective functions, and constraints. Section 5 provides a brief analysis and comparative study of different optimization strategies for VPP according to the classifications. The review analysis outcomes, concluding points, and future directions, are discussed in Section 6.

\section{Framework and the Key Contributions}

Figure 1 illustrates each section's step-by-step information flow that facilitates readers to comprehend the paper's overview. This paper presents a comprehensive analysis of different VPP based optimization strategies, techniques, and models. These strategies are classified according to their control method, system modeling, and the capability to eliminate the system's uncertainties.

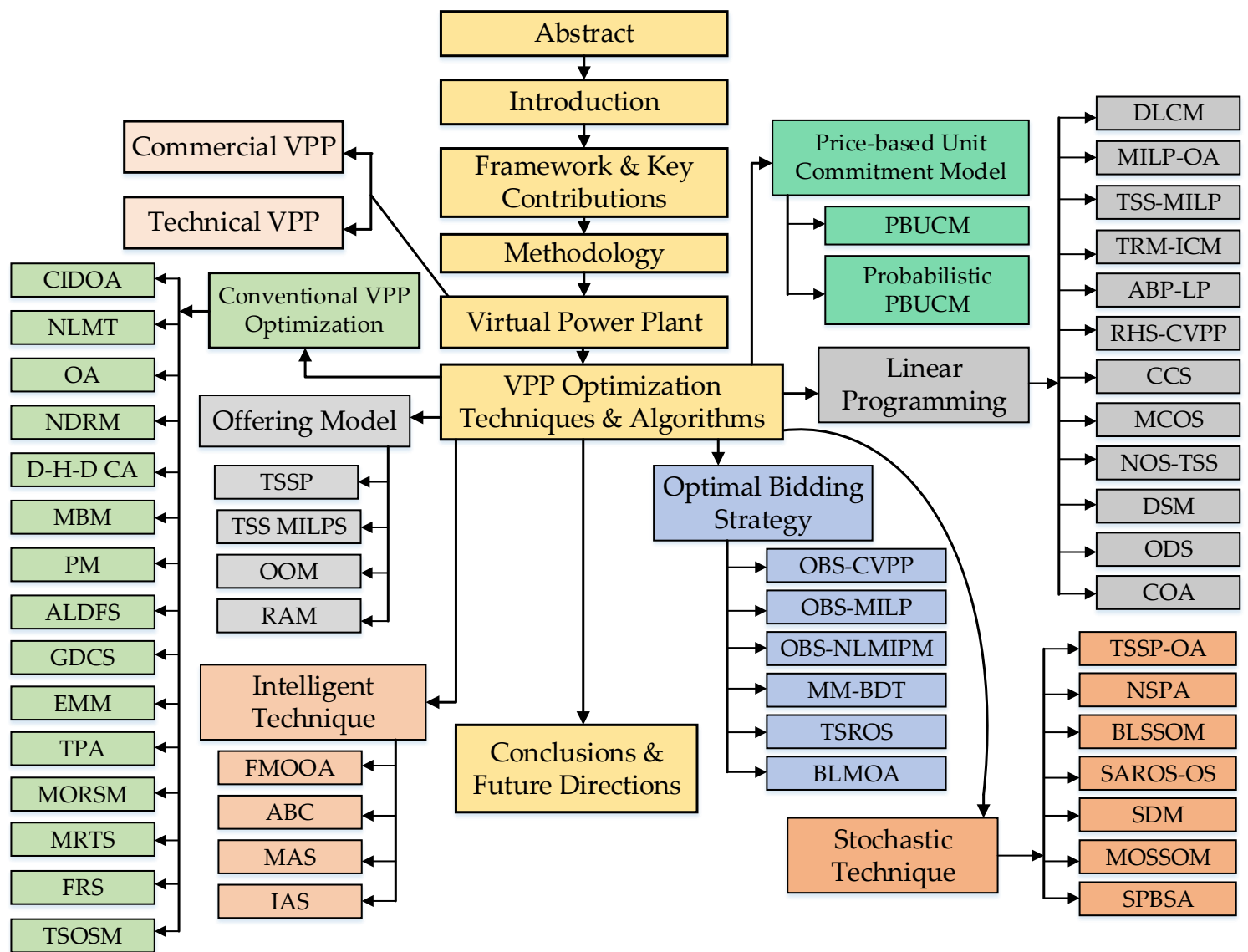

Figure 1. A representation of the information flow of this paper for a comprehensive analysis of virtual power plant optimizations.

Therefore, the significant contributions of the paper can be recounted as follows:

- To classify different optimization strategies for VPP based on system configuration, parameters, and control techniques.

- To summarize the methodology and objectives of every optimization scheme for VPP and to demonstrate the most feasible control scheme to maximize the profits with minimum cost.

- $\quad$ To depict the procedure of control flow of VPP that consists of DERs and ESSs.

- To perceive the market utilities and consumers demand responses and to designate the necessary model to deal with the electricity market.

- To analyze the causes for uncertainties in the electricity market and to demonstrate the necessary techniques to eliminate the uncertainties. 


\section{Methodology}

It is essential to gather information from the relevant sources to conduct research work on a specific object. In Figure 2, an overview of the data collection process and keyword search-based methodology is shown.

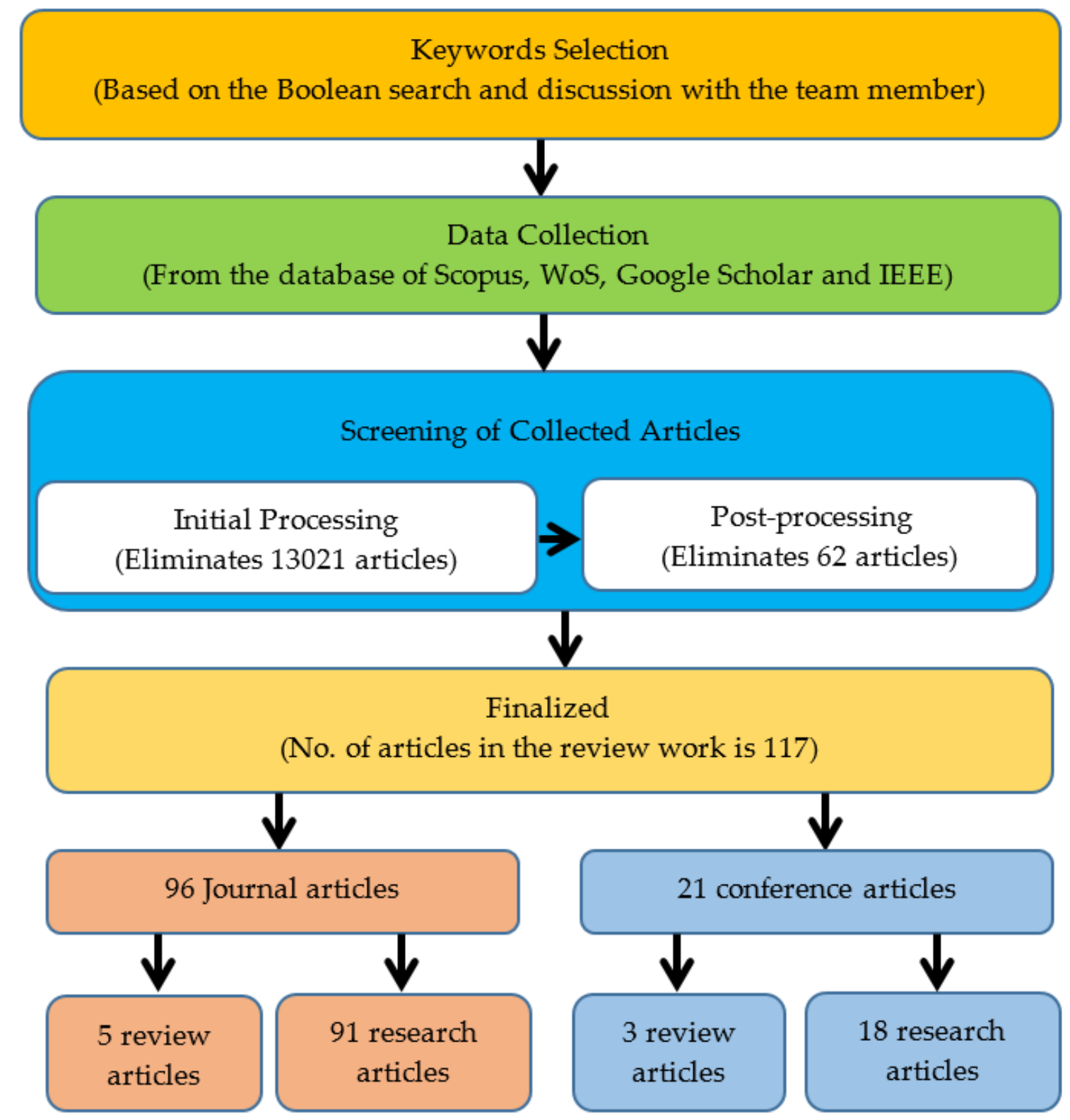

Figure 2. Representation of the data collecting process for conducting the review work.

The critical thing is to choose the related keywords for collecting research publications, and hence several discussions with the team members of this research were carried out. After rigorous discussion, the most relevant keywords are selected, which are "Virtual Power Plant", "Optimization Strategy", "Classification of Optimization strategies in VPP".

The search with the generalized keyword "Virtual power plant" results in 13,200 research publications until now. The search is then narrowed down by adding the keyword "Optimization Strategy" with the previous keyword "Virtual power plant", which results in 179 articles. The search with the keyword "Classification of optimization strategies in VPP" ensures no available articles that classify the existing optimization strategies in VPP as the author's best knowledge. The different sources 
considered in the search include IEEE, Energy, Web of Science (WOS), Scopus, and Google Scholar. While collecting the data for the presented review work, it is ensured that the considered articles are peer-reviewed and the renowned Scopus, WOS, and Google Scholar database. In the keyword-based screening process, about 13,021 articles are eliminated, and 179 articles are considered. Analyzing this literature with the research object in terms of relevance, acceptance, and pertinence, the team members ultimately selected 117 works of literature (96 journals and 21 conference proceedings) and eliminated others. Among the 96 journal articles, 91 are research articles, and only 5 are review articles.

Furthermore, among the considered 21 conference proceedings, only 3 of them are only reviewed articles, which indicate that very few articles are published to review the optimization strategies of the VPP. It plays a crucial role in motivating the presented research work. The finalized 117 works of literature were utilized and explored to conduct the proposed review analysis.

\section{Virtual Power Plants}

VPP proves itself as the alternative to the conventional transmission-based power generation plant. Conventional generation plants (CGPs) have some aspects that are needed to be followed, such as the schedule of generation, limits of the number of generations, power losses, the relationship between demand and availability of power, and so on. CGP generally integrates different DERs that follow a specific power management system. Lack of proper management in CGP results in inefficient power management with less technical and economic feasibility. VPP is the representation of integrating different DERs that overcomes the barrier of CGP by creating a single operating platform with the available generation and distribution units, as shown in Figure 3.

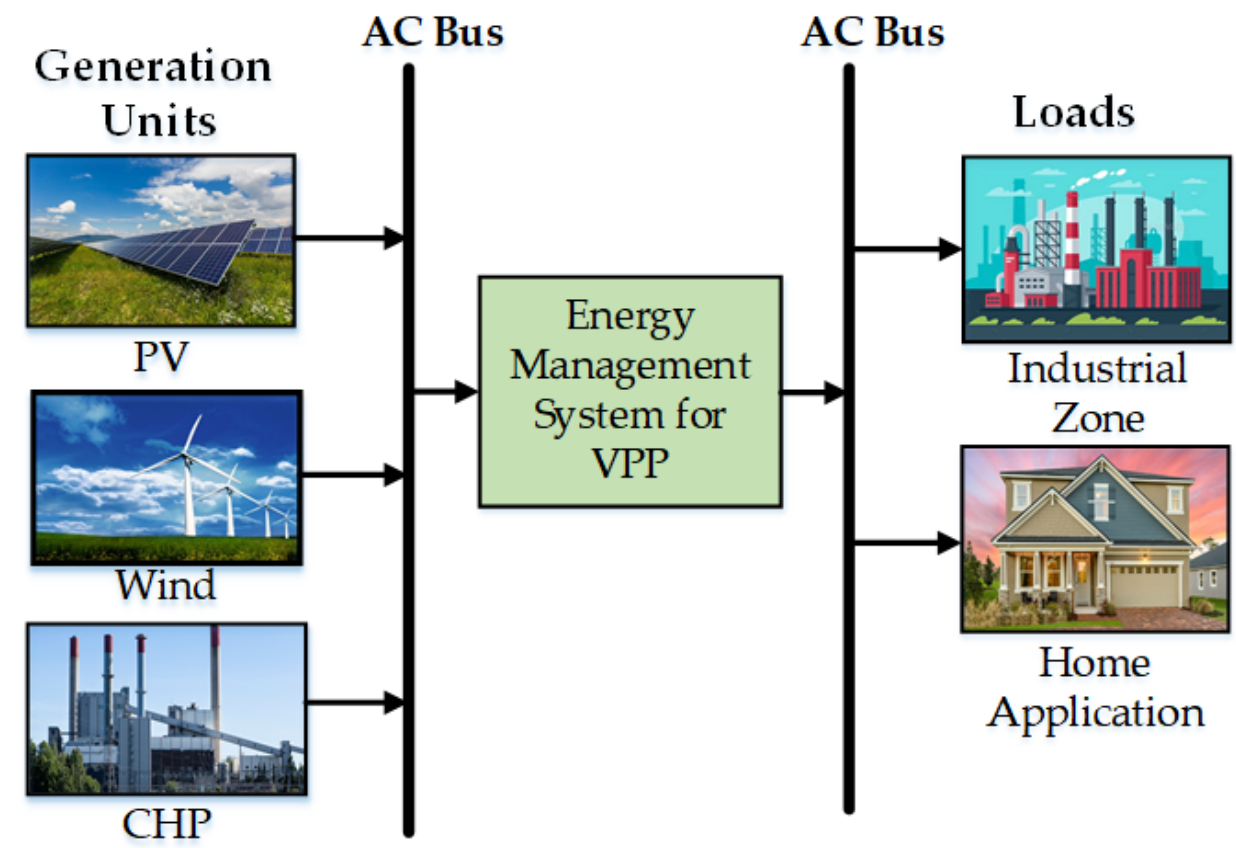

Figure 3. An overview of VPP consists of several generations and distribution units and is managed by an appropriate energy management system (Note: AC-alternating current; DC-direct current; PV-photovoltaics; VPP-virtual power plants; CHP-combined heat and power).

VPP considers different parameters to operate, such as schedule of generation and distribution, power demand concerning generation, voltage regulation capability, consumer behavior, cost-efficacy, and so on. VPP utilizes DERs to ensure the optimal power flow among the sources and fulfill the electricity market [1]. VPP introduces flexible cooperation between energy distribution strategies and market demand response feasibility. It focuses on creating a mathematical combination of DERs to present a reliable power management system. VPP can be expressed as 'Energy Internet Hub' as it can 
be controlled and operated by the wireless technology sitting in a remote position [35]. A generalized framework of VPP is illustrated in Figure 4, which indicates that VPP focuses on different aspects that provide optimal power distribution and fulfills demand response to the electricity market.

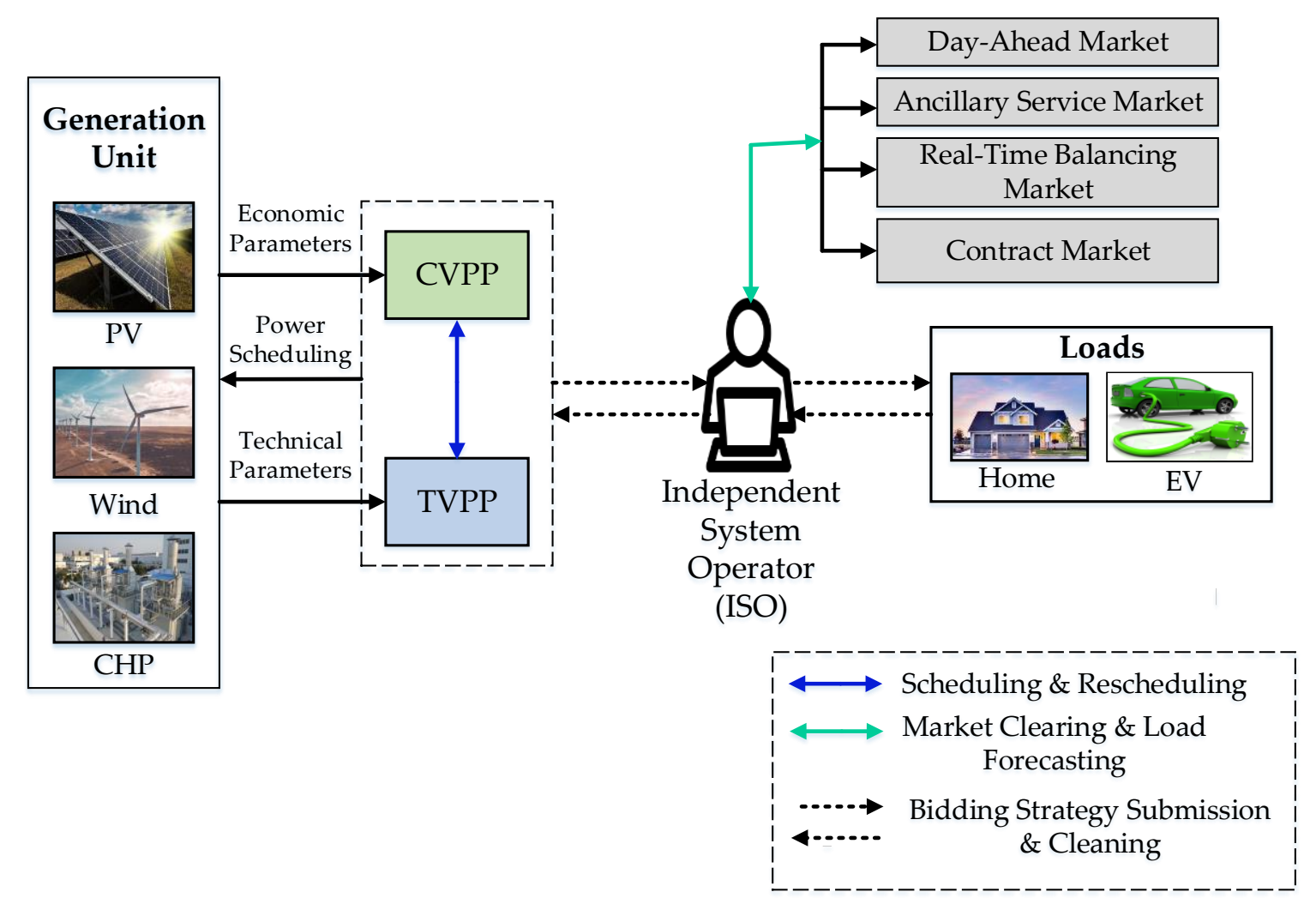

Figure 4. A basic framework of virtual power plant consisting of distributed energy resources. (Note: PV-photovoltaics; CHP-combined heat and power; CVPP-commercial virtual power plant; TVPP-technical virtual power plant; EV-electric vehicle).

\subsection{Commercial Virtual Power Plant}

CVPP mainly emphasizes financial aspects in the electricity market that intends to maximize the profits with minimum system cost. CVPP integrates different DERs concerned with the precise marginal cost and the rational evaluation of energy market conditions [36].

The marginal cost is considered for the prior scheduling of renewable energy sources [37]. Numerous DERs from different locations are integrated through CVPP and can be maintained by the operator sitting at any geographical location. CVPP determines the electricity market's current load demand and previous information to utilize DERs in the energy market. It reduces the imbalance and risks from the system and introduces high efficiency with minimum cost.

\subsection{Technical Virtual Power Plant}

TVPP observes system management of a VPP that engages several DERs and ESSs. It facilitates the optimal operation of DERs and considers the marginal cost of the system. It mainly focuses on monitoring the activities of DERs that are connected with local networks to fulfill the load demand in the electricity market. TVPP determines the values of different technical parameters and real-time data to ensure the optimal operation and management of the VPP. It provides a secure and safe way of process and maintains a better connection with CVPP. TVPP collects different information from CVPP, such as the maximum capacity of each DERs and ESSs, forecasted values of future requirements, the geographical locations of each DERs and ESSs, available control strategies of the 
system, and so on [38]. According to this information, TVPP takes some necessary steps to run the optimal operation of VPP.

\subsection{Objective Functions and Constraints}

VPP integrates DERs, ESSs, and flexible loads that consider specific objective functions to maintain the optimal operation. The objective functions mainly focus on maximizing system profits and benefits with minimum cost. Figure 5 presents different objective functions of VPP in terms of various aspects, such as generation unit, main grid, energy storage, end consumers, and so on.

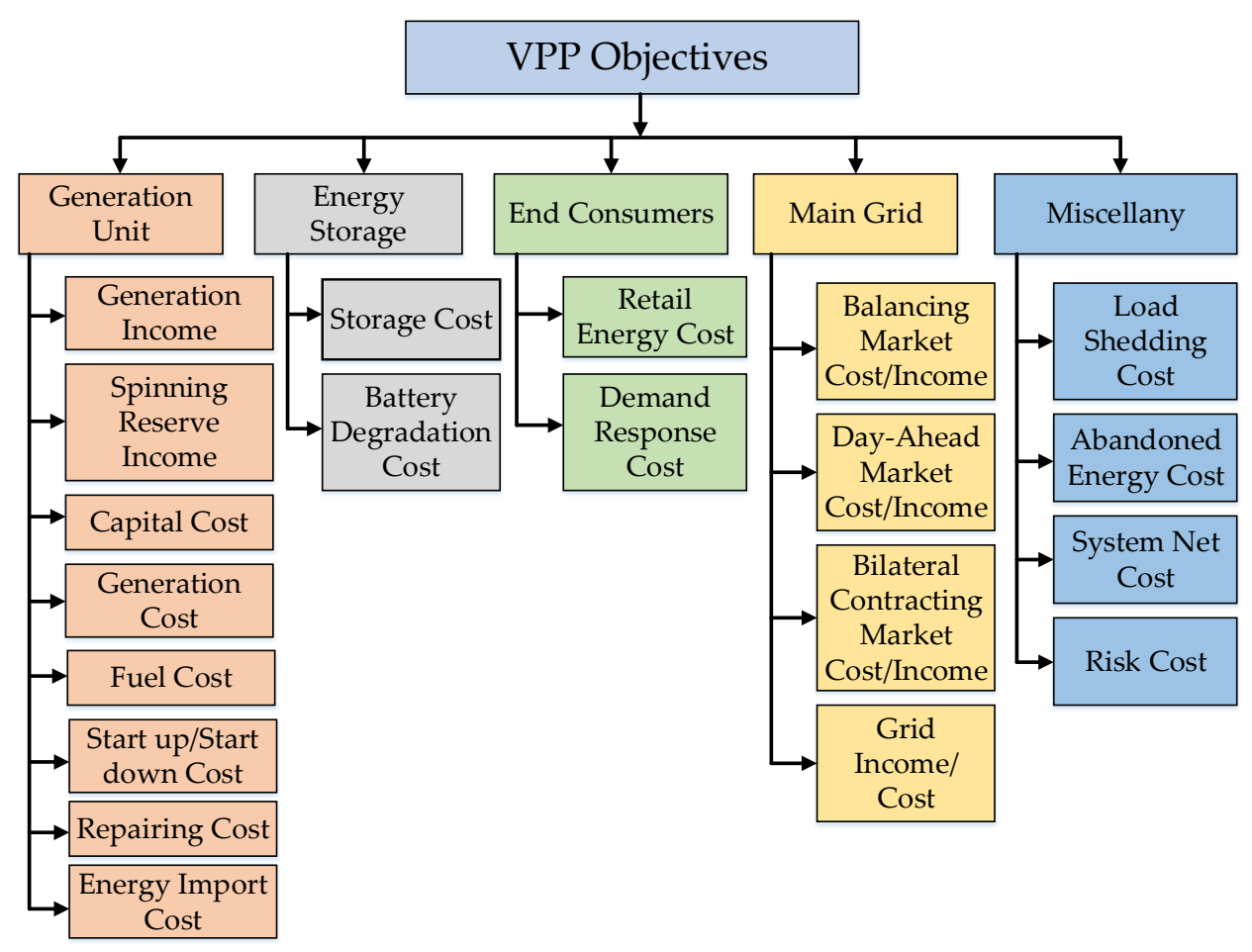

Figure 5. A classification of different optimization objectives of the virtual power plant (VPP).

The generation unit depicts four objective functions: generation income, capital cost, operational cost, and spinning reserve income. Capital cost [39-46] and operational cost [28,33,42-44,47-64] provides the cost of generation, where the generation income $[33,48,50,62,63]$ from electricity market and spinning reserve income [47,51-54] compensate the cost. The main grid includes balancing market income/cost $[43,46,52-54,57,58,61,64]$ that balances among different sections in the electricity market such as consumers, distributors, effects, etc. Bilateral contracting cost/income $[36,48,55,56]$ is another objective function of the main grid representing a contract among consumers, producers, and distributors regarding power distribution in the electricity market. The main grid presents day-ahead market cost/income $[41,45,50,51,53,54,56,64]$ as another objective function that deals with day-ahead market scheduling in the electricity market. Storage cost $[33,36,43,48,51]$ acts as an objective function of energy storage that considers the cost of storing energy in storage devices. The effect of battery degradation affects the cost of energy storage in the battery, and hence battery degradation cost [44] acts as an objective function of energy storage. There is a cost for end consumers to consume retail energy and consider demand response in the electricity market. Hence, end customers consider retail energy cost $[42,43,45,47,49,51,55,56,59]$ and demand response cost $[33,36,43,45,47-51,59,62]$ as objective function. Figure 5 also illustrates some other objective functions, such as load shedding cost [48], risk cost [36,40,44,53,54], abandoned energy cost [62], and system net load cost [33].

Figure 6 demonstrates the different constraints for VPP that concern the optimal operation of VPP in the energy market. The demand and supply balance constraints consider supply and distribution 
networks' cooperation to attain the consumers' satisfaction. Fusion space distance constraints provide a specific range to maintain the optimal operation [65]. VPP output constraint presents an output range that indicates maximum and minimum output level. Curve volatility constraint demonstrates the volatility of the curve that maintains curve feasibility and system stability. Resource complementary constraint focuses on eliminating the uncertainties from the system and on improving resilience. Consumers follow startup-start downtime constraints when the price of electricity is changed, and time is needed to adjust the change. Operation situation constraint provides the idea to undertake the scheduling in terms of demand response of consumers. Load curtailment constraint and load climbing constraint consider consumer's load demand and ensure satisfaction. Demand response (DR) operation constraint and conventional power plant (CPP) operation constraint maintain the load demand and regard the consumer's behavior in the electricity market schedule. EV charging-discharging constraint provides a period for charging and discharging the EV. System reserve constraint implies the consumer's power reservation instead of power consumption [66].

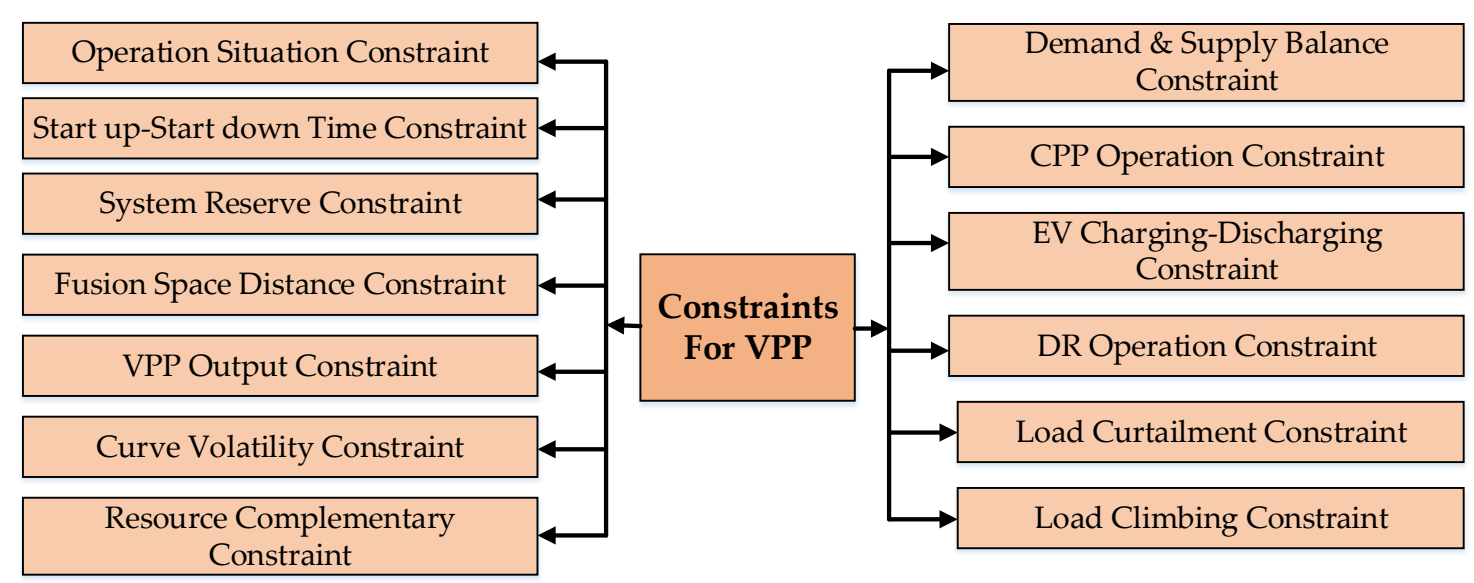

Figure 6. A representation of different constraints for virtual power plant optimization. (Note: VPPvirtual power plant; CPP-conventional power plant; EV-electric vehicle; DR; demand response).

\section{Virtual Power Plant Optimization Models, Techniques, and Algorithms}

The VPP contains numerous generation and distribution units to supply and meet the load demand. Therefore, an optimization strategy is required in VPP to handle the smooth operations between the sources and the consumers. Several optimization strategies, models, and algorithms are proposed in the literature and utilized in different applications. The presented research work categorizes the available optimization strategies into seven categories, as shown in Figure 7. They are conventional strategy, offering model, intelligent technique, price-based unit commitment (PBUC) model, optimal bidding strategy, linear programming, and stochastic method. The categorized seven optimization strategies, their corresponding forms, and a comparison between them are delineated below.

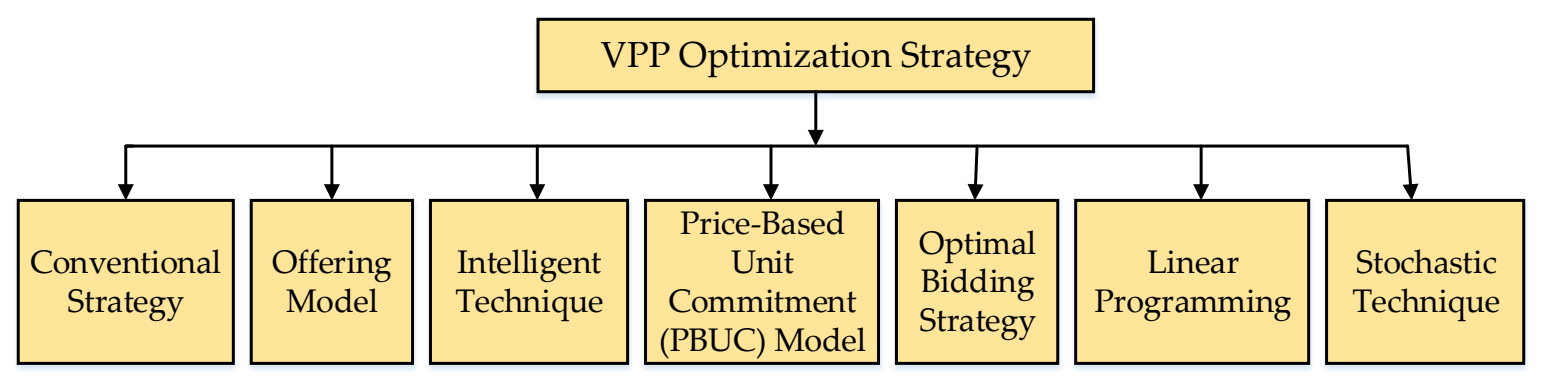

Figure 7. A classification of different optimization strategies for virtual power plants (VPP). 


\subsection{Conventional VPP Optimization Strategy}

Several conventional VPP optimization strategies are available in the literature. A combined interval and deterministic optimization approach are proposed in [67], where small-scaled DERs are included to resolve the dispatch problem. This approach mainly focuses on maximizing the market profits as well as eliminating the uncertainties. Interval optimization handles uncertainties and deterministic optimization concerns about maximizing system profits. Compared with other methods, such as stochastic optimization, robust optimization, and deterministic optimization, this approach is a fast, reliable, and better-performing tool than different approaches. Considering $\boldsymbol{P}$ as profit intervals and $P^{d}$ as deterministic profits that maximizes profits, the maximum profit can be determined by the Equations (1) and (2).

$$
\begin{gathered}
\operatorname{Max} \beta \times P^{d}+(1-\beta) \times \boldsymbol{P} \\
h(x, y)=0 \\
g(x, \boldsymbol{y}) \geq 0 \\
h\left(x, y_{0}\right)=0 \\
g\left(x, y_{0}\right) \geq 0 \\
\operatorname{Max} \beta \times P^{d}+(1-\beta)[m(\boldsymbol{P})+(\xi-1) \times w(\boldsymbol{P})] \\
\boldsymbol{H}=h(x, \boldsymbol{y}) \\
\boldsymbol{G}=g(x, \boldsymbol{y}) \\
m(\boldsymbol{H})+(\xi-1) \times w(\boldsymbol{H})=0 \\
m(\boldsymbol{G})+(\xi-1) \times w(\boldsymbol{G}) \geq 0 \\
h\left(x, y_{0}\right)=0 \\
g\left(x, y_{0}\right) \geq 0
\end{gathered}
$$

where $\beta$ is the deterministic factor, and $\xi$ is the degree of the distribution market's pessimism. $y_{0}$, presents the random forecasted values.

An optimization algorithm based on non-linear minimization techniques is proposed in [68] that focuses on minimizing the overall system cost with maximum thermal and electrical production by integrating all the DERs. The algorithm is verified at different conditions such as VPP with CHP and VPP without CHP. The variable cost related to the supply of thermal and electric energy is considered as an objective function. The objective function for optimization can be expressed as

$$
f=\sum_{n_{H}} C(H)+\sum_{n_{P}} C(P)+\sum_{n_{H c}} C(H C)+C_{\text {Grid }}
$$

where $f$ represents the total fuel cost for all the energy resources, $C_{\text {Grid }}$ presents the cost of electric energy in terms of the grid. Three terms $\left(n_{H}, n_{P}\right.$ and $\left.n_{H c}\right)$ demonstrate the cost for heat generator, power generator, and CHP plants, respectively.

In ref. [69], an approach that emphasizes designing an optimal VPP structure is discussed. This approach presents an optimal operation of VPP that controls the power flow from different sources to minimize the system cost. It reduces the loss of power from power generators and also reduces greenhouse gas (GHG) emissions. The following expression is utilized to evaluate the overall cost.

$$
T_{\text {tot_cost }}=A V_{\text {el }} T_{\text {tot_el }}+L W C W_{\text {prod }}+L H C H_{\text {prod }}+E_{p r} E_{b}+V_{\text {oll }} E_{d}
$$

where $T_{\text {tot_cost }}$ is the total cost, $A V_{e l}$ is the weighted average of the electricity generation cost, $T_{\text {tot_el }}$ is the total generated electricity, $L W C$ is the levelized freshwater cost, $W_{\text {prod }}$ is the annual freshwater production, $L H C$ is the levelized hydrogen production, $H_{\text {prod }}$ is the annual hydrogen production, $E_{p r}$ is the electricity price of the grid, $E_{b}$ is the annual electricity brought from the grid, $V_{\text {oll }}$ is the value of lost load, and $E_{d}$ is the annual electricity demand.

A novel demand response model is proposed in [60] to maximize system efficiency and benefits. The scheme introduces a fair billing system that considers consumers' load profiles at a preference 
level and does not depends on the predicted future demand responses. The minimum cost can be calculated as follows:

$$
\operatorname{Cost}_{\min }=\sum_{t=1}^{24}\left(L_{t}^{V P P} \lambda_{t}^{W}+U^{-}\right)
$$

where $L_{t}^{V P P}$ represents the total hourly load of VPP, $\lambda_{t}^{w}$ represents the hourly DA wholesale market prices and $U^{-}$represents the total system disutility.

An algorithm for CVPP is presented in [70], consisting of a wind power generator and solves a self-scheduling problem employing non-linear programming. Raab et al. [71] introduces three control strategies: direct, hierarchical, and distributed control approach that concerns the power supply to electric vehicles (EVs). The direct control approach directly controls all the power resources of the VPP, where the hierarchical system introduces an EV management module (EVMM) that minimizes the cost and maximizes the efficiency. The distributed control approach affects VPP through the energy market price. A market-based VPP model is demonstrated in [72], which comprises two scenarios: the general bidding scenario and price signal scenario and ensures the optimal use of DERs. Peikherfeh et al. [73] proposes a VPP control algorithm that maximizes the expected profit. Salmani et al. [74] presents an optimal operation of a VPP that emphasizes economic optimization that ensures the maximum output with the lowest minimum cost. It also points out other aspects, such as power quality, power distribution, consumes satisfaction, and optimal operation.

A probabilistic method is proposed in ref. [47] that consists of electrical and thermal energy resources to create optimal day-ahead scheduling, as shown in Figure 8a. The energy and reverse scheduling method and point estimate method (PEM) are employed to deal with the market price uncertainties. The objective of the proposed method is to minimize the total cost with maximum profit. The DA net profile acts as the objective function, and the maximum profit can be represented as:

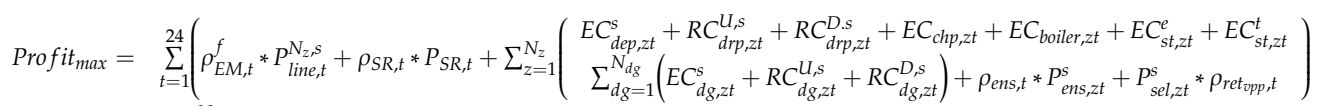

$$
\begin{aligned}
& +\sum_{\omega=1}^{N_{\omega}} \sum_{t=1}^{24} \pi_{\omega, t}
\end{aligned}
$$

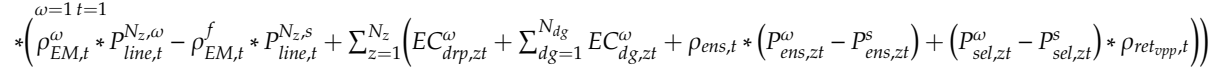

where $\rho_{E M, t}^{f}$ and $\rho_{E M, t}^{\omega}$ represents the forecasted and scenario-dependent prices in the electricity market, respectively. $P_{s e l, z t}^{\omega}$ is the scenario-based electricity demand and $P_{s e l, z t}^{s}$ is the scheduled served electricity demand in period $t$ and zone $z . \pi_{\omega, t}$ is the probability of occurrence of scenario $\omega$ in period $t$. $\rho_{S R, t}, \rho_{\text {ret }} t_{v p, t}$ and $\rho_{\text {ens }, t}$ are the spinning reserve market price, VPP's retail energy rate, and considered penalty of non-reserved in period $t$, respectively.

An adaptive load dispatching and forecasting strategy for VPP is proposed in [75], which comprises solar, wind, hydrogen, and thermal power system. A forecasting algorithm is introduced to analyze the data values for future profit from the system, and a load dispatching algorithm is applied to maintain the optimal operation. A generation driver control strategy is proposed in [76] that introduces the mesh network concept to control the power distribution between generation units and load elements, as shown in Figure 8b.

The strategy focuses on reducing the transmission losses and emphasizes the optimal operation in the smart microgrid. MATLAB is introduced as a simulation platform, and IEEE RTS 9673 bus system using Simulink is utilized for the testing. The strategy focuses on only load management, but several studies should be included, such as dynamic and priority-based load management, vertical integration of VPP with the EV charging system. The primary optimization objective to minimize transmission loss can be expressed as:

$$
P_{\text {min_loss }}=\sum_{h=1}^{24} P_{\text {loss }}
$$




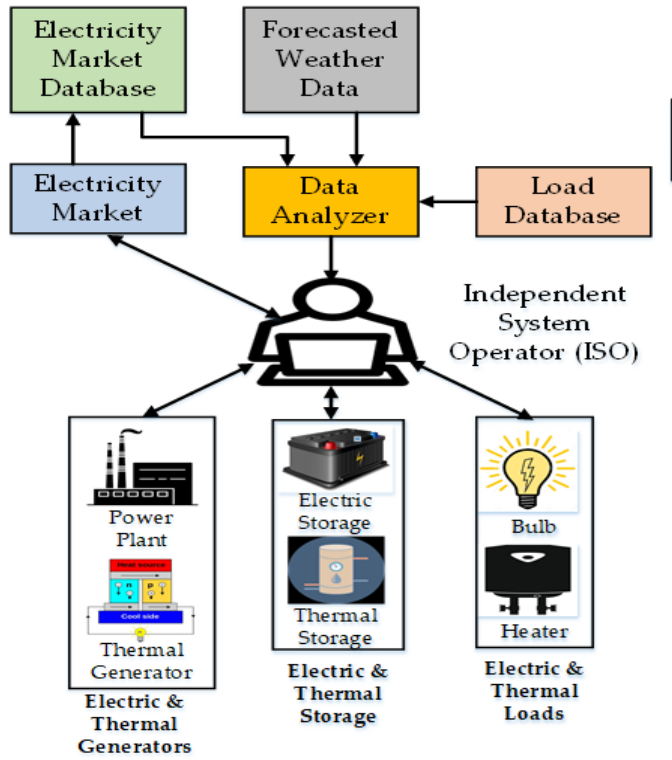

(a)

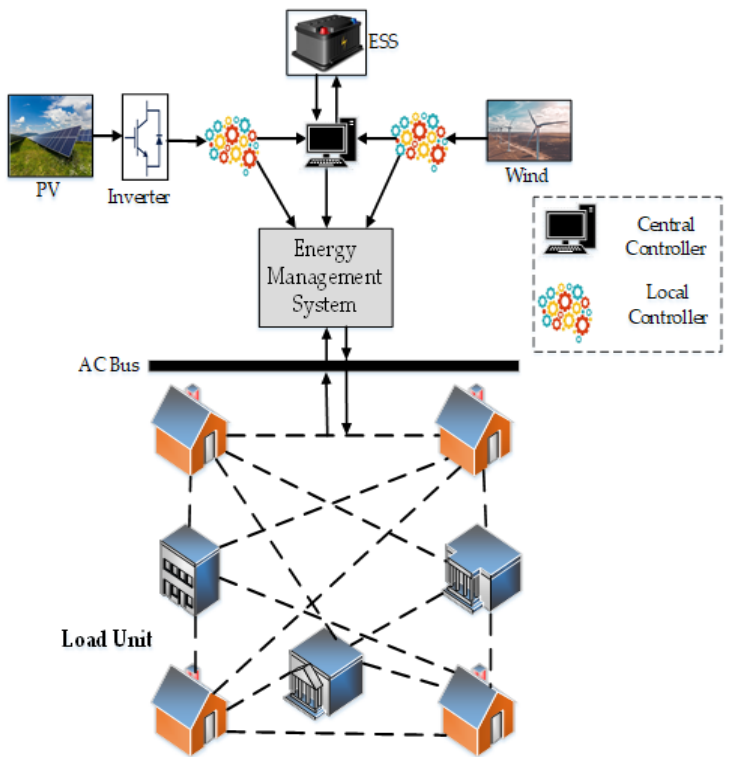

(b)

Figure 8. A schematic representation of the virtual power plant for (a) a probabilistic method (Redrawn with permission from [47], 2016, Elsevier); (b) Generation driver control strategy. (Note: PV-photovoltaics; AC-alternating current; ESS-energy storage system).

The total generated power can be represented as:

$$
P_{\text {vpp }}=P_{\text {Load }}+P_{\text {Battery }}+P_{\text {loss }}
$$

The deficiency of power at time $t$ can be expressed as:

$$
P_{v p p}^{D}=\left(P_{P V}+P_{W}\right)-\left(P_{\text {Load }}+P_{\text {loss }}\right)
$$

The power loss at any time can be expressed as:

$$
P_{\text {loss }}=P_{P V}+P_{W}-n_{0} * P_{0, \text { load }}^{i}-n_{c} * P_{c, \text { load }}^{i}-n_{n} * P_{n, \text { load }}^{i}
$$

where $n_{0}$ is the number of device off, $n_{c}$ is the number of devices operating under curtailed power and $n_{n}$ is the number of devices operating under standard rated power.

An energy management model for VPPs is presented in [40] that explores the cost and emission $\left(\mathrm{CO}_{2}, \mathrm{NO}_{x}\right)$ effects for VPP in a PHEV-penetrated electricity network. The scheme illustrates linear modeling for VPP and analyzes the sensitivity of cost and capabilities of DERs, batteries, and gasoline. The study focuses on minimizing cost and is tested in the state of California with real-time data. The minimization of cost can be illustrated as follows:

$$
\operatorname{Cost}_{\min }=\sum_{t \in T}\left(\sum_{u \in U} C_{u, t}^{E P} \times e_{u, t}^{E P}+\sum_{u \in U} C_{u}^{S U} \times S_{u, t}+\sum_{v \in V}\left(C_{t}^{g a s} \times C S_{v} \times d_{v, t}^{C S}+\left[f\left(\delta_{v, t}\right)-f\left(\delta_{v, t-1}\right)^{+}\right)\right)\right.
$$

where $C_{u, t}^{E P}$ is the price of earned energy during period $t, C_{t}^{g a s}$ is the price of gasoline during time $t$, $e_{u, t}^{E P}$ is the energy supply by $E P_{u}$ during period $t, C S_{v}$ is the average gasoline usage of $\mathrm{PHEV}, \delta_{v, t}$ is the depth of discharge (DOD) for the PHEV during period $t, f(\delta)$ is the probable battery replacement cost as a function of DOD, $d_{v, t}^{C S}$ is the charge-sustaining (CS) mode during period $t$ by the PHEV.

VPP system proposed in [77] analyzes the uncertainties and irregularities of the energy market in terms of prices and distribution management. The method involves demand-side management (DSM) 
and enables the effective integration of DERs. The system presents a platform for centralized and decentralized operations and connects VPP with the national grid system. Iacobucci et al. [78] presents the cooperation of shared autonomous electric vehicles (SAEV) and VPP with renewable energy resources (RES) that focuses on optimal operation between themselves. The proposed algorithm deals with charging and discharging EVs and emphasizes minimizing cost and saving power. The proposed scheme is tested in Tokyo, considering weather conditions and transportation systems. The objective function that expresses the cost minimization is:

$$
\operatorname{Cost}_{\min }=\sum_{t}\left(C_{\text {grid }}(t)+C_{D G}(t)+\frac{\gamma_{\text {cycles }} * c(t) * C_{b a t}}{L_{b a t}}\right)
$$

where $c(t)$ is the charge energy, $C_{b a t}$ is the cost of the battery, $L_{b a t}$ is the life of the battery in equivalent full cycle, $C_{D G}(t)$ is the cost function of $D G$ and $C_{\text {grid }}$ is the cost function of the grid. $\gamma_{\text {cycles }}$ is the battery cost during the opposite aging.

A trip-prediction algorithm is proposed in [79] for EV to grid integrating the VPP platform that mainly focuses on the optimal EV charging, shown in Figure 9a. A standard communication protocol is connected between EV to the grid that monitors the real-time data at the transmission period via instant messaging (IM) and voice-over-IP (VoIP). The proposed system serves several aspects: data storage, trip forecasting, optimization, customer relations, billing updates, and communication. A multi-objective robust scheduling model is presented in [80] that deals with power to gas-based VPP (GVPP) based on energy conversion technique and demand response, as shown in Figure $9 \mathrm{~b}$. A flexible risk aversion model is included in the GVPP, focusing on maximizing profits and minimizing risks. Robust optimization and conditional value at risk methods are introduced to eliminate the uncertainties. For the solution of multi-objective models, a three-stage algorithm is introduced: payoff table, fuzzy linearization process, and rough weight calculation. The proposed model proves an optimal platform to convert the energy from power to gas with maximum efficacy and minimum risks.

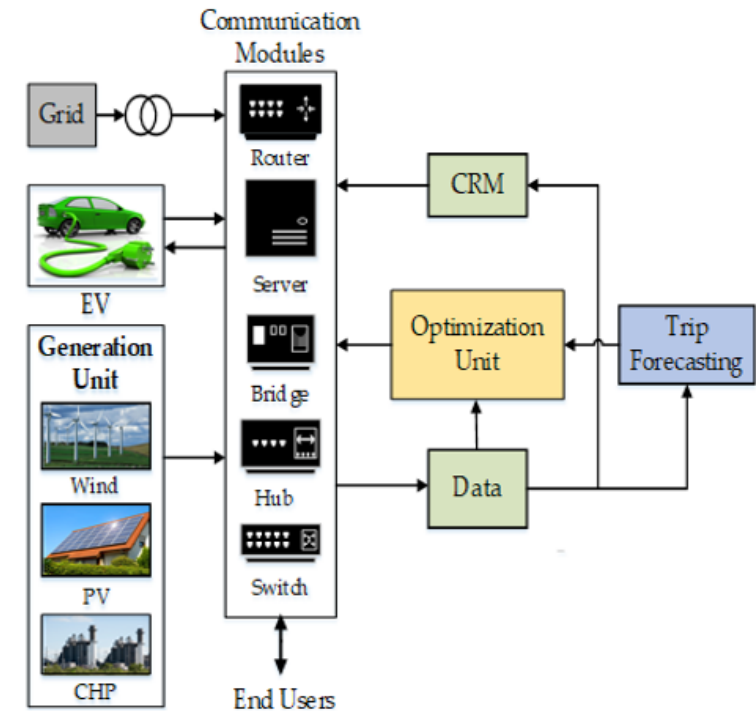

(a)

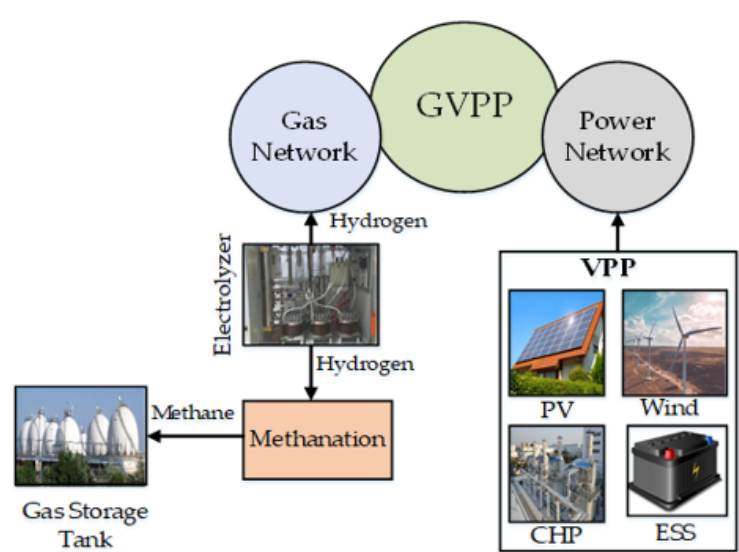

(b)

Figure 9. A schematic representation of the virtual power plant for (a) trip prediction algorithm; (b) multi-objective robust scheduling model (Redrawn with permission from [80], 2019, Elsevier). (Note: PV-photovoltaics; CHP-combined heat and power; CRM-customer relationship management; GVPP-gas based virtual power plant; VPP-virtual power plant; ESS-energy storage system).

A mixed rental-trading strategy is proposed in [81] that allows a fleet owner to provide an optimal charging and discharging platform for EV, as presented in Figure 10. The strategy intends to maximize 
the profits for the fleet owners and predicts future demand responses for day-ahead market scheduling. A frequency regulation strategy for VPP is proposed in [82] that consists of distributed energy resources (DERs), flexible loads, and ESSs. This strategy passes frequency regulated signals to each element and evaluates the VPP power management system's efficacy and competence. A significant power management system is established among generation units and loads in this system. A two-stage optimal scheduling model for VPP is presented in [83] that deals with day-ahead (DA) and real-time (RT) market schedule. The first stage introduces an hourly scheduling strategy that maximizes system profits in the DA market.

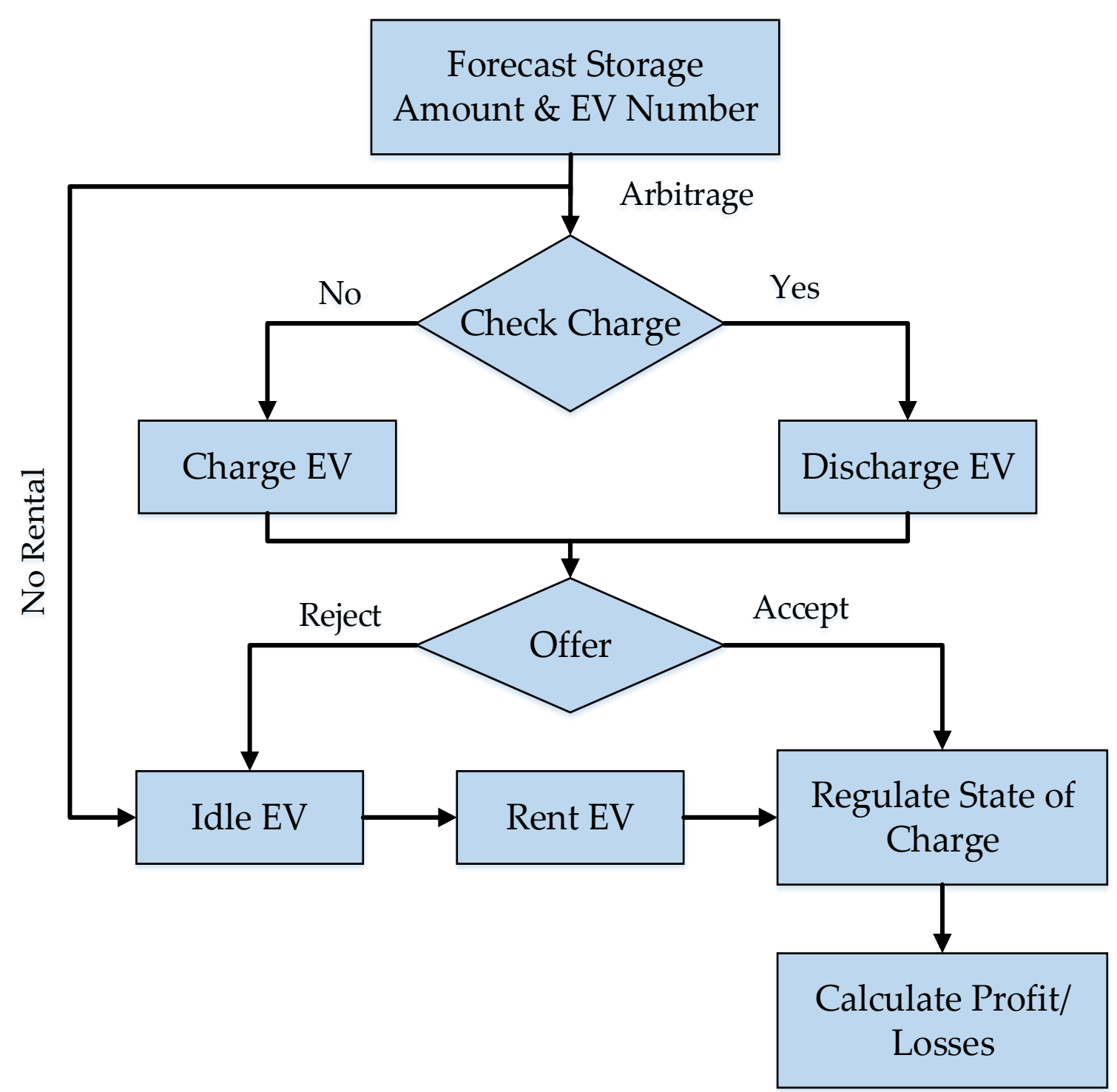

Figure 10. A mixed rental-trading strategy for the virtual power plant coupled with electric vehicle (EV). (Redrawn with permission from [81], 2018, Wiley Periodicals, Inc. on behalf of Production and Operations Management Society).

In contrast, the second stage minimizes system costing in the RT market by harmonizing VPP output. The conditional value at risk $(\mathrm{CVaR})$ is applied to alleviate the risk factors. The proposed model analyzes and eliminates risks and uncertainties of the VPP by introducing particle swarm optimization (PSO) and commercial solver. An optimization method for VPP is demonstrated in [84] that considers the flexible load demands for optimal power distribution among sources in a low voltage distribution platform. A direct control scheme is introduced to control the power consumption 
due to heat and formulates an optimization problem. Robu et al. [85] presents a scoring rules-based optimization scheme that provides a significant formation for integrating DERs of a cooperative VPP (CVPP). The scoring method predicts future demands accurately and is verified in 16 real-world wind firms in the UK.

The afore-mentioned twenty-two different conventional approaches for the optimization of VPP are compared in terms of system configuration and critical features and presented in Table 1.

Table 1. A comparative analysis among different conventional approaches for virtual power plants.

\begin{tabular}{|c|c|c|c|}
\hline Ref & $\begin{array}{l}\text { Optimization } \\
\text { Approach }\end{array}$ & $\begin{array}{l}\text { System } \\
\text { Configuration }\end{array}$ & Key Features \\
\hline [40] & $\begin{array}{l}\text { Energy } \\
\text { management } \\
\text { model }\end{array}$ & DER and ESS & $\begin{array}{ll}\text { - } & \text { Analyzes cost and emission impacts } \\
\text { - } & \text { Introduces PHEV-penetration network } \\
\text { - } & \text { The sensitivity of cost and emissions of DER and gasoline } \\
\text { - } & \text { Presents linear modeling of VPP } \\
\text { - } & \text { Minimizes system cost }\end{array}$ \\
\hline [47] & $\begin{array}{l}\text { A probabilistic } \\
\text { method }\end{array}$ & $\begin{array}{l}\text { Electrical and } \\
\text { thermal energy } \\
\text { resources }\end{array}$ & $\begin{array}{l}\text { - } \quad \text { Considers ESS and demand response programs } \\
\text { - } \quad \text { Point Estimate Model (PEM) and Energy and Reverse } \\
\text { Scheduling method to deal with uncertainties } \\
\text { - } \quad \text { Minimize cost and maximize profits }\end{array}$ \\
\hline [60] & $\begin{array}{l}\text { A novel } \\
\text { demand } \\
\text { response model }\end{array}$ & DER & $\begin{array}{l}\text { - Demand response acts as a primary factor to the } \\
\text { proposed system } \\
\text { - Mainly focuses on modeling a fair billing system not } \\
\text { depending on forecast values of future demand } \\
\text { - The proposed billing system depends on customers } \\
\text { behavior and demand response } \\
\text { - } \quad \text { Ensures maximum profits with minimum cost }\end{array}$ \\
\hline [67] & $\begin{array}{l}\text { Combined } \\
\text { interval and } \\
\text { deterministic } \\
\text { optimization } \\
\text { approach }\end{array}$ & $\begin{array}{l}\text { Small scaled } \\
\text { DER }\end{array}$ & $\begin{array}{l}\text { - } \quad \text { Interval optimization handles uncertainties } \\
\text { - } \quad \text { Deterministic optimization concerns about system profits } \\
\text { - } \quad \text { Less computation time } \\
\text { - }\end{array}$ \\
\hline [68] & $\begin{array}{l}\text { Non-linear } \\
\text { minimization } \\
\text { techniques }\end{array}$ & $\begin{array}{l}\text { CHP plant, } \\
\text { electrical and } \\
\text { thermal energy } \\
\text { storage system, } \\
\text { energy } \\
\text { exchanger }\end{array}$ & $\begin{array}{l}\text { - } \quad \text { Considers cost function in the power distribution system } \\
\text { - } \text { dinimizes production cost with feasible power } \\
\text { - } \quad \text { Performs the test with CHP and again without CHP }\end{array}$ \\
\hline [69] & $\begin{array}{l}\text { Optimization } \\
\text { algorithm }\end{array}$ & $\begin{array}{l}\text { CHP, } \\
\text { Renewable } \\
\text { energy sources } \\
\text { (PV, wind) }\end{array}$ & $\begin{array}{l}\text { - } \quad \text { Optimal power flow among sources } \\
\text { - } \quad \text { Power distribution management with minimum cost } \\
\text { - } \quad \text { Reduction of GHG emission } \\
\text { - } \quad \text { Concerns about loss of energy }\end{array}$ \\
\hline [70] & $\begin{array}{l}\text { Non-linear } \\
\text { programming } \\
\text { based } \\
\text { optimization } \\
\text { algorithm }\end{array}$ & $\begin{array}{l}\text { Wind power } \\
\text { generation unit }\end{array}$ & $\begin{array}{l}\text { - Maintains system operation with demand responses } \\
\text { - The problem is solved via non-linear programming }\end{array}$ \\
\hline
\end{tabular}


Table 1. Cont.

\begin{tabular}{|c|c|c|c|}
\hline Ref & $\begin{array}{l}\text { Optimization } \\
\text { Approach }\end{array}$ & $\begin{array}{l}\text { System } \\
\text { Configuration }\end{array}$ & Key Features \\
\hline [71] & $\begin{array}{l}\text { A direct, } \\
\text { hierarchical, } \\
\text { and distributed } \\
\text { control } \\
\text { approach }\end{array}$ & DER & $\begin{array}{l}\text { - Introduces three control strategies: direct, hierarchical, } \\
\text { and distributed control strategy } \\
\text { - } \quad \text { Direct control directly controls power flow } \\
\text { - } \quad \text { Hierarchical control applies an EV management module } \\
\text { (EVMM) that minimizes cost } \\
\text { - } \quad \text { Distributed control observes the market price }\end{array}$ \\
\hline [72] & $\begin{array}{l}\text { A market-based } \\
\text { VPP model }\end{array}$ & DER & $\begin{array}{l}\text { - Optimal power distribution in the electricity market } \\
\text { - Considers the general bidding scenario and price signal } \\
\text { scenario for system operation }\end{array}$ \\
\hline [74] & $\begin{array}{l}\text { Optimal } \\
\text { operation of } \\
\text { VPP }\end{array}$ & DER & $\begin{array}{l}\text { - } \quad \text { Deals with multi-objective optimization problems } \\
\text { - } \quad \text { Focuses on economic stability and maximizes profits }\end{array}$ \\
\hline [75] & $\begin{array}{l}\text { An adaptive } \\
\text { load } \\
\text { dispatching } \\
\text { and forecasting } \\
\text { strategy }\end{array}$ & $\begin{array}{l}\text { Solar, wind, } \\
\text { hydrogen, and } \\
\text { thermal power } \\
\text { system }\end{array}$ & $\begin{array}{l}\text { - A forecasting algorithm to predict future values } \\
\text { - Load dispatching algorithm to sustain the } \\
\text { optimal operation }\end{array}$ \\
\hline [76] & $\begin{array}{l}\text { Generation } \\
\text { driver control } \\
\text { strategy }\end{array}$ & $\begin{array}{l}\text { Solar, wind, } \\
\text { and energy } \\
\text { storage system }\end{array}$ & $\begin{array}{l}\text { - } \quad \text { Introduces mesh network infrastructure } \\
\text { - } \text { Optimal power distribution from generation units } \\
\text { - } \quad \text { Lessens transmission loss } \\
\text { - } \quad \text { Emphasizes load management }\end{array}$ \\
\hline [77] & $\begin{array}{l}\text { VPP } \\
\text { optimization } \\
\text { scheme }\end{array}$ & DER and ESS & $\begin{array}{l}\text { - Analyzes irregularity and uncertainties in the } \\
\text { energy market } \\
\text { - } \quad \text { Both centralized and decentralized operation } \\
\text { - } \quad \text { Introduces demand-side management }\end{array}$ \\
\hline [78] & $\begin{array}{l}\text { An } \\
\text { optimization } \\
\text { model for } \\
\text { SAEV and VPP }\end{array}$ & $\begin{array}{l}\text { Solar, wind, } \\
\text { and dispatch } \\
\text { generation } \\
\text { units }\end{array}$ & $\begin{array}{l}\text { - Optimal operation between SAEV and VPP } \\
\text { with microgrids } \\
\text { - } \quad \text { Saves power and minimizes cost } \\
\text { - } \quad \text { Considers weather conditions and transportation system }\end{array}$ \\
\hline [79] & $\begin{array}{l}\text { Trip-prediction } \\
\text { algorithm }\end{array}$ & $\begin{array}{l}\text { Renewable } \\
\text { energy } \\
\text { resources } \\
\text { (RERs) and ESS }\end{array}$ & $\begin{array}{l}\text { - } \quad \text { EV to VPP integration } \\
\text { - } \quad \text { Communication protocol with IM and VoIP } \\
\text { Optimal operation of EV charging }\end{array}$ \\
\hline [80] & $\begin{array}{l}\text { The } \\
\text { multi-objective } \\
\text { robust } \\
\text { scheduling } \\
\text { model }\end{array}$ & $\begin{array}{l}\text { WPP, PV, gas } \\
\text { storage tank }\end{array}$ & $\begin{array}{l}\text { - Power to the gas energy conversion process } \\
\text { - Considers demand response and uncertainties } \\
\text { - Three-stage algorithm for optimal solution: payoff table, } \\
\text { fuzzy linearization, and rough weight calculation } \\
\text { - Maximizes profits and minimizes risks }\end{array}$ \\
\hline [81] & $\begin{array}{l}\text { Mixed } \\
\text { rental-trading } \\
\text { strategy }\end{array}$ & $\begin{array}{l}\text { DER, Battery, } \\
\text { and EV }\end{array}$ & $\begin{array}{l}\text { - } \quad \text { Predicts future demand responses } \\
\text { - } \quad \text { Maximizes profits and minimizes system cost } \\
\text { Optimal charging and discharging platform }\end{array}$ \\
\hline
\end{tabular}


Table 1. Cont.

\begin{tabular}{|c|c|c|c|}
\hline Ref & $\begin{array}{l}\text { Optimization } \\
\text { Approach }\end{array}$ & $\begin{array}{l}\text { System } \\
\text { Configuration }\end{array}$ & Key Features \\
\hline [82] & $\begin{array}{l}\text { Frequency } \\
\text { regulation } \\
\text { strategy }\end{array}$ & $\begin{array}{l}\text { DER, flexible } \\
\text { loads, and ESS }\end{array}$ & $\begin{array}{l}\text { - } \quad \text { Decomposes regulated frequencies in each unit } \\
\text { - Optimal power management among sources and loads }\end{array}$ \\
\hline [83] & $\begin{array}{l}\text { The two-stage } \\
\text { optimal } \\
\text { scheduling } \\
\text { model }\end{array}$ & $\begin{array}{l}\text { Energy storage } \\
\text { system } \\
\text { (Battery), } \\
\text { Gas-fired } \\
\text { microturbine, } \\
\text { wind power } \\
\text { generators }\end{array}$ & $\begin{array}{l}\text { Two-stage scheduling: the first stage maximizes profits } \\
\text { of the DA market, and the second stage minimizes } \\
\text { system costing in the RT market } \\
\text { - } \quad \text { CVaR lessens uncertainties and risk of VPP } \\
\text { - } \quad \text { Considers as a risk-hedging tool } \\
\text { - Introduces PSO and commercial solver }\end{array}$ \\
\hline
\end{tabular}

Note: DER-distributed energy resources; ESS-energy storage systems; PHEV-plug-in hybrid electric vehicle; VPP-virtual power plant; CHP-combined heat and power; PV-photovoltaics; GHG-greenhouse gas; SAEE-standard autonomous electric vehicle; WPP-wind power plant; EV-electric vehicle; IM-instant messaging; VoIP-voice over internet protocol; DA-day ahead; RT-realtime; CVaR-conditional value at risk; PSO-particle swarm optimization).

\subsection{Offering Model}

An offering model based on two-stage stochastic programming is presented in [86], consisting of DERs such as wind and cascade hydro-power systems. The model concerns the day ahead, offering to eliminate the uncertainties of the VPP. An offering model for VPP based on a two-stage stochastic mixed-integer linear programming scheme is demonstrated in [87] that comprises DERs, a storage facility, and a power plant. This model concerns about fulfilling the day-ahead market power demand with the maximum profit. The model is validated as a reliable control scheme to design an economically feasible VPP with high computational efficiency.

The objective function of the proposed scheme is expressed as follows:

$$
\begin{gathered}
\text { Profit }_{\max }=\sum_{t=1}^{T} \sum_{w=1}^{n_{w}} \pi_{w w} \sum_{p=1}^{n_{p}} \pi_{p} \sum_{r_{r d o w n}=1}^{n_{r}^{\text {down }}} \pi_{r}^{\text {down }} \sum_{r_{r}^{u p}=1}^{n_{r}^{u p}} \pi_{r}^{u p} \\
{\left[\lambda_{p}(t)\left(G_{w p}(t)+m_{w p}^{\text {down }}(t) * \psi_{r}^{\text {down }}(t)-b m_{w p}^{u p}(t) * \psi_{r}^{u p}(t)\right)-C_{w p}^{c}(t)-S U C^{c} * v_{w p}^{c}(t)\right]}
\end{gathered}
$$

where $\pi_{r}^{\text {down }}$ and $\pi_{r}^{u p}$ are the probability of the $r^{\text {th }}$ down-regulation and up-regulation price scenario respectively, $\psi_{r}^{\text {down }}$ and $\psi_{r}^{u p}$ are the down-regulation and up-regulation price ratio in time $t$ respectively, $b m_{w w p}^{\text {down }}$ and $b m_{w p}^{u p}$ are the power sell and purchase in balancing market, respectively. SUC $C^{c}$ is the CPP start-up cost. $C_{w p}^{c}(t)$ is the total cost of the CPP electricity production. $\lambda_{p}(t)$ is the DA market price in time $t$ and scenario $p$.

Mohammadi et al. [88] presents an offering optimization model for VPP that consists of a wind power plant (WPP) and flexible loads, as shown in Figure 11. The model analyzes the operation of VPP at different uncertainties and results in a feasible outcome. A risk aversion model is presented in [89] for analyzing different offering strategies that consist of a wind power plant (WPP) and focus on the optimal operation of the VPP. The mentioned four model optimizations are compared and presented in Table 2.

\begin{tabular}{|c|c|c|c|}
\hline Ref & Optimization Approach & System Configuration & Key Features \\
\hline [86] & $\begin{array}{l}\text { Offering a model based } \\
\text { on two-stages stochastic } \\
\text { programming }\end{array}$ & $\begin{array}{l}\text { DERs (wind and cascade } \\
\text { hydro-power system) }\end{array}$ & $\begin{array}{ll}\text { - } & \text { Considers day-ahead market prices } \\
\text { - } & \text { Eliminates uncertainties } \\
\text { - } & \text { Cope with electricity market responses }\end{array}$ \\
\hline
\end{tabular}

Table 2. A comparative analysis among different offering models for virtual power plants. 
Table 2. Cont.

\begin{tabular}{|c|c|c|c|}
\hline Ref & Optimization Approach & System Configuration & Key Features \\
\hline [87] & $\begin{array}{l}\text { Offering a model based } \\
\text { on a two-stage stochastic } \\
\text { mixed-integer linear } \\
\text { programming scheme }\end{array}$ & $\begin{array}{l}\text { DERs, storage facility, } \\
\text { and a power plant (wind } \\
\text { power plant) }\end{array}$ & $\begin{array}{l}\text { Maximizes profit considering } \\
\text { day-ahead market prices } \\
\text { and responses } \\
\text { - Uncertainties: market prices and } \\
\text { power of generation units } \\
\text { - Less computation time }\end{array}$ \\
\hline [88] & $\begin{array}{l}\text { Offering optimization } \\
\text { model }\end{array}$ & $\begin{array}{l}\text { WPP and storage unit } \\
\text { (flexible loads) }\end{array}$ & $\begin{array}{l}\text { - A combined operation of WPP and } \\
\text { demand response } \\
\text { - } \quad \text { Aims to increase system profits } \\
\text { - } \quad \text { Flexible loads act as a storage unit as } \\
\text { well as a generation unit }\end{array}$ \\
\hline [89] & Risk aversion model & WPP & $\begin{array}{l}\text { - Analyzes risks for different optimal } \\
\text { offering strategies }\end{array}$ \\
\hline
\end{tabular}

Note: DERs-distributed energy resources; WPP-wind power plant.

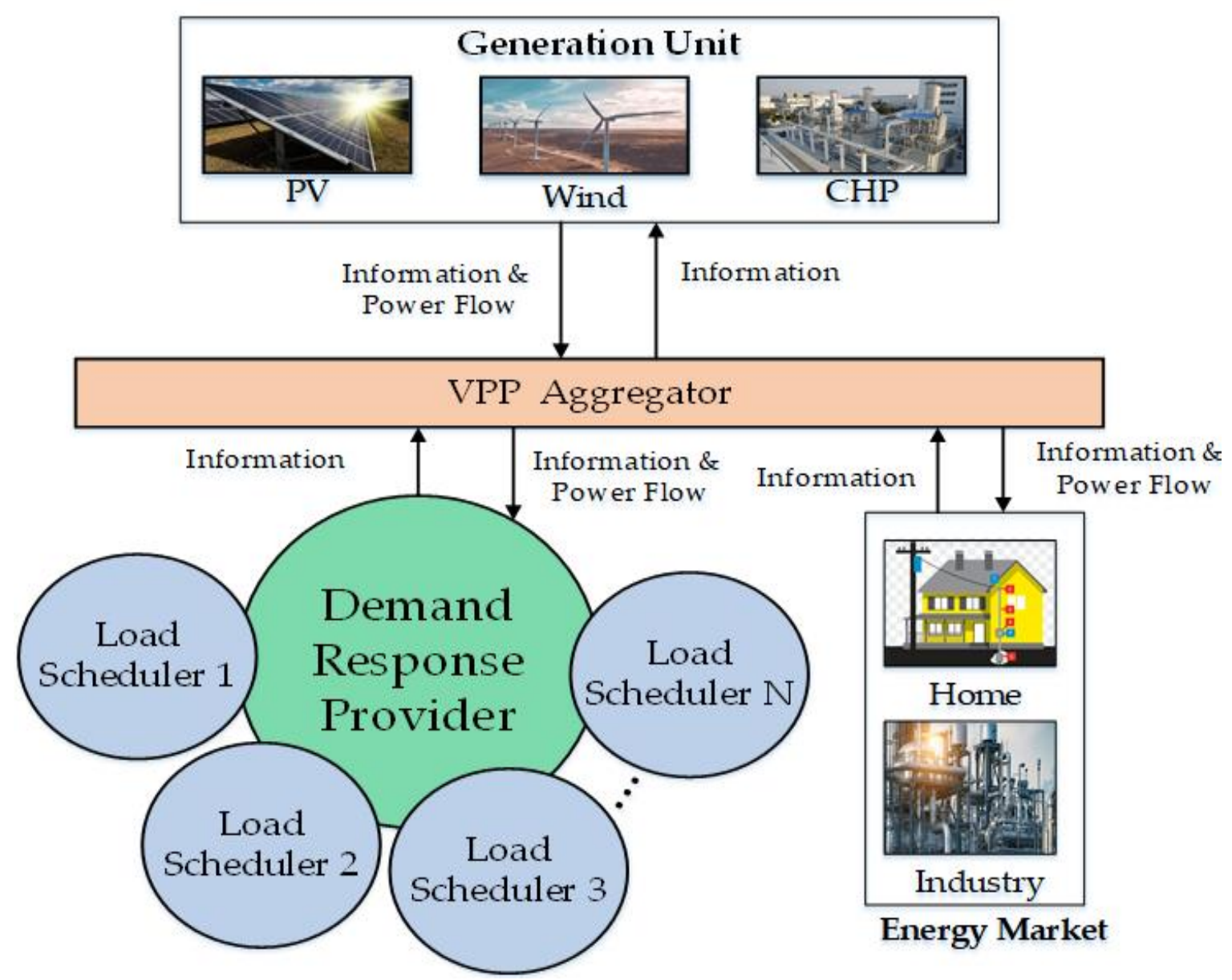

Figure 11. Offering optimization model for virtual power plants. (Note: PV-photovoltaics; CHPcombined heat and power; VPP-virtual power plant). 


\subsection{Optimization Algorithm Based on Intelligent Techniques}

Fuzzy multiple objective optimization algorithms are introduced in [90] that focuses on optimal power management of VPP, as shown in Figure 12a,b. The proposed algorithm operates on the priority requirement concept, and it considers the system efficiency, optimal power distribution, system cost, and consumer's and supplier's contentment. The algorithm addresses the two-step interactive satisfactory optimization principle to obtain the priority requirements. It is verified as a feasible and reliable VPP algorithm by implementing a test in renewable energy sources.

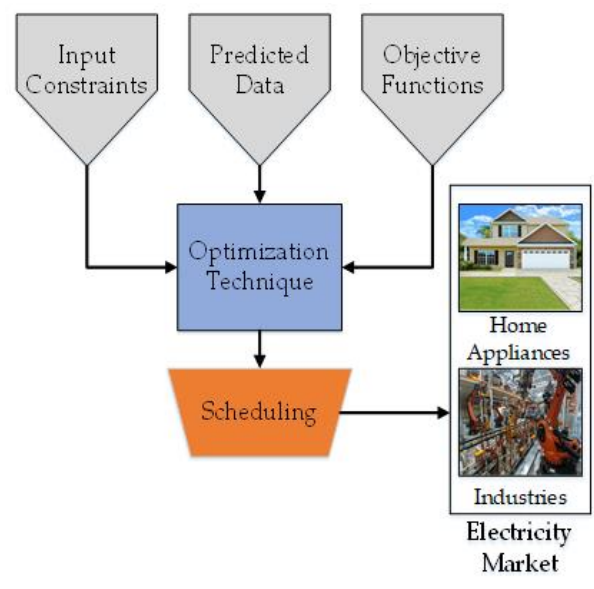

(a)

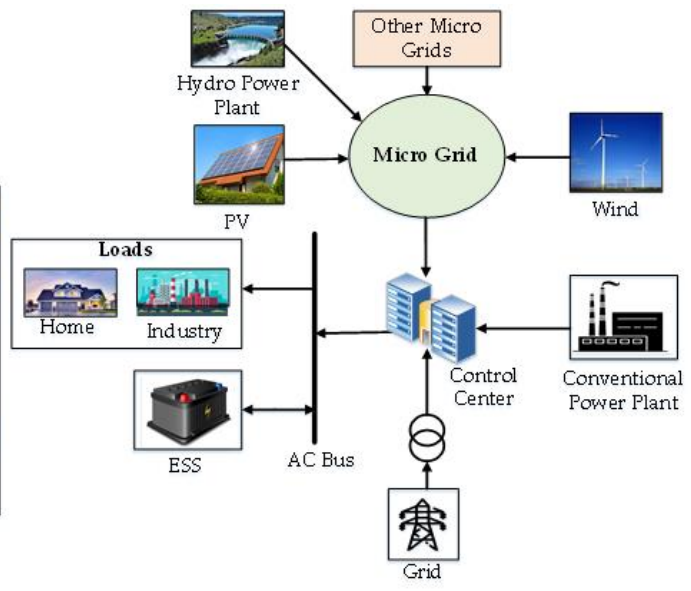

(b)

Figure 12. (a). Fuzzy based multiple objective optimization algorithms for virtual power plant; (b). co-ordination model for the distributed energy resources-based virtual power plant. (Redrawn with permission from [90], 2011, MDPI). (Note: AC-alternating current; PV-photovoltaics; ESS-energy storage system).

An agent-based control for VPP is proposed in [91] that includes MAS (multi-agent system) technique to facilitate the VPP operation and maximize economic benefits. The schematic representation of agent-based control is shown in Figure 13. The concept concerns micro-grid and distribution units' optimal operation and hence utilizes local intelligence and communication technology via the MAS technique. MAS does not rely on the central decisions and can take proper steps according to the environmental changes. The system is validated in a different test site with three-level MAS, i.e., field, management, and enterprise levels, that assert a better VPP control system.

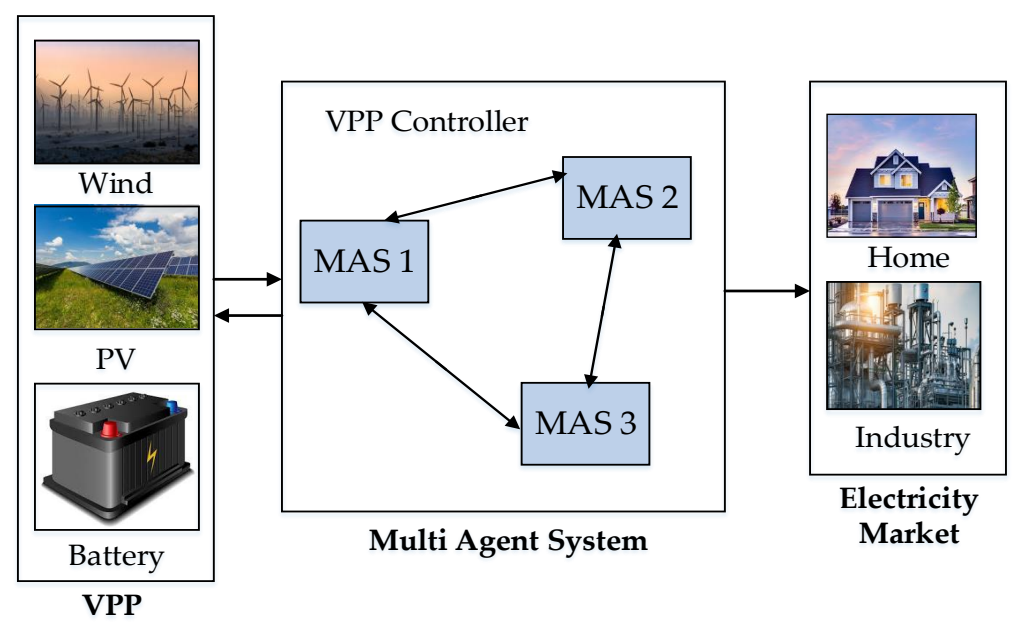

Figure 13. A multi-agent system-based co-ordination between the virtual power plant and electricity markets (Note: PV-photovoltaics; VPP-virtual power plants; MAS-multi agent system). 
A MAS for the smart grid is demonstrated in [46] that focuses on integrating different small and intelligent elements to optimize VPPs. The proposed MAS introduces a demand forecasting algorithm based on the artificial neural network (ANN) that predicts future demands and consumer behaviors in energy markets. The scheme is capable of ensuring optimal modeling of VPPs with different elements and opens an easy platform. The intelligent auto-control system (IAS) for VPP is presented in [92], focusing on optimal power distribution from generation units to loads. The system comprises a control coordination center (CCC) that controls optimal power distribution among the sources. The proposed IAS lessens transmission losses, maximizes system profits, and sustains system stability.

The IAS follows two methods:

(i) Load distribution by generation units with priority level and

(ii) Load distribution by generation units equally. Another, MAS for VPP is presented in [93] to control the generation units' carbon emissions.

The proposed scheme mainly focuses on establishing environment VPP (EVPP) by considering the hierarchical control. Multi-agents can be classified as EVPP integration agents, micro-generator, and micro-grid. The proposed scheme provides high accuracy in the energy distribution system. The discussed intelligent technique for the optimization of the VPP is summarized and compared in Table 3.

Table 3. An analysis of a virtual power plant optimization algorithm based on the intelligent technique.

\begin{tabular}{|c|c|c|c|}
\hline Ref & $\begin{array}{l}\text { Optimization } \\
\text { Approach }\end{array}$ & $\begin{array}{l}\text { System } \\
\text { Configuration }\end{array}$ & Key Features \\
\hline [46] & $\begin{array}{l}\text { A multi-agent } \\
\text { system (MAS) }\end{array}$ & $\begin{array}{l}\text { PV, wind, } \\
\text { biomass plant, } \\
\text { EV, and ESS }\end{array}$ & $\begin{array}{l}\text { - } \quad \text { The forecasting algorithm is based on ANN } \\
\text { - } \quad \text { Predicts future demands and customer behavior } \\
\text { - } \quad \text { Optimal modeling of VPP } \\
\text { - } \quad \text { Different level of MAS for optimal operation }\end{array}$ \\
\hline [90] & $\begin{array}{l}\text { Fuzzy multiple } \\
\text { objective } \\
\text { optimization } \\
\text { algorithms }\end{array}$ & $\begin{array}{l}\text { Renewable } \\
\text { generation } \\
\text { sources }\end{array}$ & $\begin{array}{l}\text { - Optimal power management considering } \\
\text { priority requirement } \\
\text { Two-step interactive satisfactory optimization method is } \\
\text { employed to maintain the priority level as well as an } \\
\text { acceptable level } \\
\text { - Emphasizes system stability, maximum profits, and } \\
\text { minimum cost }\end{array}$ \\
\hline [91] & $\begin{array}{l}\text { Agent-based } \\
\text { control }\end{array}$ & $\begin{array}{l}\text { PV generator, } \\
\text { wind turbine, } \\
\text { battery, diesel } \\
\text { generator, and } \\
\text { CHP plant }\end{array}$ & $\begin{array}{l}\text { - Introduces a multi-agent system (MAS) } \\
\text { - Three-level MAS: field level, management level, } \\
\text { and enterprise-level } \\
\text { - } \quad \text { Facilitates VPP control and operation } \\
\text { - Focuses on economic efficacy }\end{array}$ \\
\hline [92] & $\begin{array}{l}\text { Intelligent } \\
\text { Auto-control } \\
\text { System (IAS) }\end{array}$ & $\begin{array}{l}\text { Distributed } \\
\text { energy } \\
\text { resources (DER) } \\
\text { and flexible } \\
\text { loads }\end{array}$ & $\begin{array}{ll}\text { - } & \text { Optimal power distribution between sources and loads } \\
\text { - } & \text { CCC controls power distribution } \\
\text { - } & \text { Reduces transmission loss } \\
\text { - } & \text { Sustains system stability and reliability } \\
\text { - } & \text { Maximizes system profits }\end{array}$ \\
\hline [93] & $\begin{array}{l}\text { A multi-agent } \\
\text { system (MAS) }\end{array}$ & $\begin{array}{l}\text { PV, battery, fuel } \\
\text { cell, diesel } \\
\text { generator, and } \\
\text { micro CHP } \\
\text { plant }\end{array}$ & $\begin{array}{ll}\text { - } & \text { Controls carbon emission } \\
\text { - } & \text { Considers environmental efficacy } \\
\text { - } & \text { Hierarchical control structure } \\
\text { - } & \text { Higher accuracy }\end{array}$ \\
\hline
\end{tabular}

Note: PV-photovoltaics; ESS-energy storage systems; ANN-artificial neural network; CHP-combined heat and power; VPP-virtual power plant; CCC-control coordination center. 


\subsection{Priced-Based Unit Commitment (PBUC) Model}

A PBUC model is introduced in [41] for VPP with security constraints to earn the maximum profit from the energy market and satisfy the consumers. Peik-herfeh et al. [94] presents another PBUC system that concerns the economic benefits, and thus the point estimate method (PEM) is introduced. The outcomes of the design represent a feasible scheme with high profit. A probabilistic PBUC approach is proposed in [2] that focuses on maximizing the expected profit considering the day-ahead electricity market. The PEM is employed to design a model for eliminating uncertainties of VPP, and the mixed-integer linear programming is introduced to solve a system problem. The objective function of PBUC can be expressed as:

$$
\begin{gathered}
\text { Profit }_{\max }=\sum_{k}\left(\text { revenue }^{k}-\operatorname{cost}^{k}\right) \\
\text { revenue }^{k}=\sum_{k}\left(P_{D \text { emand }}^{k}+P_{\text {Loss }}^{k} * \rho_{D S O}^{k}+\sum_{k} P_{V P P, G S P}^{k} * \lambda_{D M, G S P}^{k}\right. \\
\operatorname{cost}^{k}=\sum_{D G}\left(C_{D G} * P_{D G}^{k} * \alpha_{D G}^{k}+S U C_{D G} * \beta_{d g}^{k}+S D C_{D G} * \gamma_{D G}^{k}\right)+\sum_{S G} C_{S G} * P_{S G}^{k} * \alpha_{D G}^{k}+C_{D L}^{k} * P_{D L}^{k}
\end{gathered}
$$

where $P_{D L}^{k}$ is the curtailment value of dispatchable load in an hour, $C_{D L}^{k}$ is the cost of an interruptible consumer to curtail its load in an hour, $\alpha_{D G^{\prime}}^{k} \beta_{D G}^{k}$ and $\gamma_{D G}^{k}$ presents the binary decision (on = 1, off = 0) for $D G$ unit status, start-up, and shunt down in hours, respectively. $C_{D G}$, and $C_{S G}$ represent the generation costs of dispatchable and stochastic $D G$ units, respectively. $S U C_{D G}$ and $S D C_{D G}$ represent the start-up and shut down the cost of the $D G$ unit, respectively.

The existing three PBUC model for the optimization of VPP are compared in Table 4 in terms of system configuration and critical features. It is seen that the PBUC model maximizes the profit of the system by the DA management system, flexible loads, and ESS and utilizes PEM to tackle the uncertainties of the system.

\begin{tabular}{|c|c|c|c|}
\hline Ref & $\begin{array}{l}\text { Optimization } \\
\text { Approach }\end{array}$ & $\begin{array}{l}\text { System } \\
\text { Configuration }\end{array}$ & Key Features \\
\hline [2] & $\begin{array}{l}\text { A probabilistic } \\
\text { PBUC approach for } \\
\text { optimal bidding of } \\
\text { VPP }\end{array}$ & $\begin{array}{l}\text { DER, ESS sand } \\
\text { loads }\end{array}$ & $\begin{array}{l}\text { - } \quad \text { Considers wind speed, temperature } \\
\text { - } \quad \text { Utilize PEM for uncertainties } \\
\text { and market prices } \\
\text { - } \quad \text { Maximum profit for day-ahead market } \\
\text { electricity management }\end{array}$ \\
\hline [41] & PBUC model & $\begin{array}{l}\text { Energy Storage, } \\
\text { flexible loads, } \\
\text { and CPP }\end{array}$ & $\begin{array}{l}\text { - } \quad \text { Considers network topology and security constraints } \\
\text { - } \quad \text { Maximizes profits with minimum system cost }\end{array}$ \\
\hline [94] & PBUC model & $\begin{array}{l}\text { PV, wind power } \\
\text { plant, flexible } \\
\text { loads, energy } \\
\text { storage, and } \\
\text { CPP }\end{array}$ & $\begin{array}{l}\text { - } \quad \text { Point estimate method (PEM) to compute the } \\
\text { market condition } \\
\text { - Maximizes profit using flexible loads and ESS. }\end{array}$ \\
\hline
\end{tabular}

Table 4. A comparative analysis among different priced-based unit commitment models for virtual power plant.

Note: PBUC-priced-based unit commitment; VPP-virtual power plant; DER-distributed energy resources; ESS-energy storage systems; PEM-point estimate method; CPP-conventional power plant; PV-photovoltaics. 


\subsection{Optimal Bidding Strategy}

An optimal bidding strategy for commercial VPP is proposed in [95], consisting of DERs and introduces a three-stage bi-level optimization model. The bi-level model's upper level illustrates the maximum profit, where the low level deals with ISO day-ahead market clearing problem. A demand response aspect is also introduced, and the bi-level model is converted into mixed-integer linear programming for solving a complex issue. Zdrilić et al. [96] presents an optimal bidding strategy that incorporates a mixed-integer linear programming algorithm to solve an involved cost and profit problem. The system consists of solar, wind, and gas power plant. A bidding strategy is proposed in [63], a nonlinear mixed-integer programming model based on a deterministic PBUC technique. The strategy has solved the problem by introducing a genetic algorithm (GA) and manages DERs by establishing a single operating profile.

The objective function of the proposed scheme to maximize benefits can be expressed as:

$$
\begin{gathered}
\text { Benefit }_{\text {max }}=-\sum_{t=1: 24} \rho_{E, t} \times E_{t}+\sum_{t=1: 24} \rho_{R, t} \times R_{t}+\sum_{t=1: 24} \rho_{L, t} \times \text { Load }_{t} \\
-\sum_{i \in S_{d g}}\left(C_{d g, i, t}\left(P_{d g, i, t}+R_{d g, i, t}\right) * I_{i, t}+S C_{d g, i, t} *+S H C_{d g, i, t} * K_{i, t}\right) \\
-\sum_{\substack{i \in S_{\text {int }} \\
t \in S_{\text {hour }, t}}} C_{\text {int }, i, t}\left(P_{\text {curt }, i, t}+R_{\text {curt }, i, t}\right)-\sum_{i \in S_{\text {str }}} C_{\text {str }, i, t}\left(P_{\text {str }, i, t}\right) \\
\text { Load }_{t}=\operatorname{LOAD}_{t}-\sum_{\substack{i \in S_{\text {int }} \\
t \in S_{\text {hour }, i}}}\left(P_{\text {curt }, i, t}+R_{\text {curt }, i, t}\right)
\end{gathered}
$$

where $L O A D_{t}$ is the total forecasted load of VPP, $S C_{d g, i, t}$ and $S H C_{d g, i, t}$ are the shut up and shut down the cost of DG, $\rho_{E, t}$ is the price of the energy market, $\rho_{R, t}$ is the price of spinning reserve market, $\rho_{L, t}$ is the retail energy rate of VPP, $P_{\text {curt }, i, t}$ is the unserved load for trading in the energy market, and $P_{d g, i, t}$ is the generation of DG in the energy market.

An optimal bidding strategy consists of CHP-DH and DERs is proposed in [97] that focuses on eliminating the uncertainties of energy market price and power generation. The system addresses two-stage stochastic programming. This paper presents a comparative study for three different methods based on the optimal bidding strategy: static, flexible DA, and flexible RT. Chaves-Ávila et al. [98] presents a bidding strategy that consists of WPP and lessens market price and power generation uncertainties. A two-stage robust optimization scheme is proposed in [99] that consists of WPP and other electrical resources and analyzes price-demand responses. In the first stage, a bidding strategy is introduced to analyze day-ahead market prices and then transferred to the second stage for real-time solutions. Market price uncertainties are eliminated via robust optimization. A mathematical approach for optimal bidding of VPP is presented in [100] based on the Benders decomposition technique. The system provides security for the DERs and VPP. A bi-level multi-objective approach for strategic bidding equilibrium of VPP is presented in [101], where the upper level emphasizes maximum profits, and the lower-level deals with maximizing social welfare. The bi-level approach mainly concerns with the behavior of producers and consumers. The optimization problem is solved by mixed-integer linear programming (MILP) which involves duality theory and Karush-Kuhn-Tucker (KKT) optimization conditions. IEEE-24 bus system is applied as a testing platform of the proposed scheme.

As mentioned above, a total of eight existing optimal bidding strategies for VPP are compared in Table 5, which illustrates that most of the strategy utilizes a bi-level optimization model to curb the uncertainty issues, a MILF model or GA to solve the complex problem, maximize the profit of the system with optimal cost and heat and power distribution and also considers the security and stability constraints. 
Table 5. A comparative analysis among different optimal bidding strategies for virtual power plant.

\begin{tabular}{|c|c|c|c|}
\hline Ref & Optimization Approach & System Configuration & Key Features \\
\hline [95] & $\begin{array}{l}\text { Optimal bidding strategy } \\
\text { for commercial virtual } \\
\text { power plant (VPP) }\end{array}$ & $\begin{array}{l}\text { Distributed energy } \\
\text { resources (DER), battery } \\
\text { storage systems (BSS) }\end{array}$ & $\begin{array}{l}\text { - Three-stage stochastic bi-level } \\
\text { optimization model to } \\
\text { handle uncertainties } \\
\text { - } \quad \text { Maximizes profits with minimum cost } \\
\text { - } \quad \text { Considers demand response } \\
\text { - } \quad \text { MILP is introduced to solve } \\
\text { complex problems }\end{array}$ \\
\hline [96] & $\begin{array}{l}\text { Optimal bidding strategy } \\
\text { based on mixed-integer } \\
\text { linear programming } \\
\text { algorithm }\end{array}$ & $\begin{array}{l}\text { Solar, wind, and gas } \\
\text { power plant }\end{array}$ & $\begin{array}{l}\text { - Considers long-term } \\
\text { bilateral contracts } \\
\text { - } \quad \text { MILP to face complex problems }\end{array}$ \\
\hline [63] & $\begin{array}{l}\text { Bidding strategy for the } \\
\text { non-linear mixed-integer } \\
\text { programming model }\end{array}$ & DER & $\begin{array}{l}\text { - } \quad \text { A non-linear MILP model } \\
\text { - } \quad \text { Introduces the deterministic } \\
\text { PBUC technique } \\
\text { - } \quad \text { A genetic algorithm } \\
\text { - } \quad \text { Oor problem-solving } \\
\text { Optimal integration among DERs }\end{array}$ \\
\hline [97] & Optimal bidding strategy & $\begin{array}{l}\text { Combined heat and } \\
\text { power }(\mathrm{CHP}) \text { and } \\
\text { renewable energy } \\
\text { resources (RES) }\end{array}$ & $\begin{array}{l}\text { - Uncertainties due to output power of } \\
\text { generation unit and market prices } \\
\text { CHP-district heating (CHP-DH) deals } \\
\text { with uncertainties } \\
\text { - } \quad \text { Relative analysis among three bidding } \\
\text { strategies: static, flexible day-ahead, } \\
\text { and flexible Realtime } \\
\text { - Maximizes profits with optimal heat } \\
\text { and power distribution } \\
\text { - Introduces MILP }\end{array}$ \\
\hline [98] & Bidding strategy & Wind power plant (WPP) & $\begin{array}{l}\text { - Analyzes bidding in the } \\
\text { electricity market }\end{array}$ \\
\hline [100] & $\begin{array}{l}\text { A mathematical model } \\
\text { based on Benders } \\
\text { decomposition technique }\end{array}$ & $\begin{array}{l}\text { DER and VPP } \\
\text { security constraints }\end{array}$ & $\begin{array}{l}\text { - Considers system and } \\
\text { security constraints } \\
\text { - Concerns about system stability and } \\
\text { system efficacy }\end{array}$ \\
\hline [101] & $\begin{array}{l}\text { Bi-level multi-objective } \\
\text { approach }\end{array}$ & DER & $\begin{array}{l}\text { - Bi-level approach: upper level for } \\
\text { profit optimization and lower level to } \\
\text { maximize social welfare } \\
\text { Duality theory and karush kuhn } \\
\text { tucker optimization conditions } \\
\text { for MILP } \\
\text { - Utilize IEEE-24 bus system as a } \\
\text { validation platform }\end{array}$ \\
\hline
\end{tabular}

Note: MILP-mixed-integer linear programming; PBUC-priced-based unit commitment; IEEE-institute of electrical and electronics engineering. 


\subsection{Optimization Algorithm Based on Linear Programming}

A mixed-integer linear programming (MILP) method is proposed in [102] that comprises different energy sources and deals with self-scheduling problems. An agent-based control scheme for VPP presented in [59] includes wind generators and concerns about improving system profit through linear programming. An optimization model for VPP is proposed in [103] that addresses two-stage stochastic mixed-integer linear programming to design a VPP for both day-ahead and balancing market. The model consists of DERs such as PV, wind farms, and battery banks. It introduces risk factors and the conditional value at risk (CVaR) to remove uncertainties and earn the expected profit. The objective function of the proposed scheme can be represented in terms of maximum profit.

$$
\left.\operatorname{Profit}_{\max }=\sum_{t=1}^{T}\left(\sum_{w=1}^{n_{w}} \pi(w) * \sum_{s=1}^{n_{s}} \pi(P)\left(\lambda^{P}(t)\left(G_{P}(t)+0.7 P_{w s p}^{u p}(t)-1.3 P_{w s p}^{d o w n}(t)\right)-\sum_{j=1}^{2} O C_{j}(t)-y(t)\right)_{j, w s p} * C_{S u, j}-S_{w s p p, j}(t)\right)\right)+\beta R \text { Risk }
$$

where $G_{P}(t)$ is the day-ahead market, $P_{w s p}^{u p}$ is the electricity sell and $P_{w s p}^{\text {down }}$ is the electricity purchase. $B$ represents the importance of risk minimization.

An interactive cooperation model based on two risk management approaches, such as the $\mathrm{CVaR}$ and second-order stochastic dominance constraints (SSD), is proposed in [104] that deals with medium level energy resources and takes steps against uncertainties in market prices. The model addresses mixed-integer linear programming to deal with complex problems and introduces an off-the-shelf-software package to evaluate the solution. The model focuses on the economic aspects of the VPP that intends to maximize the profit with minimum cost. A coordinated control strategy for VPP is proposed in [105] that comprises of PV and controllable loads and intends to design an optimal platform for the power distribution. The strategy aims to adjust the VPP output power in a wide range. It finds out the solution via linear integer programming, and experimental simulation is implemented using DIgSILENT software. A risk hedging strategy is presented in [106] for commercial VPP that deals with cross bilateral contracting and medium-term self-scheduling problem to pertain optimal solutions. The strategy faces price uncertainty by introducing first-order stochastic dominance constraints (FSD). It addresses mixed-integer linear programming (MILP) problem that is evaluated through an off-the-shelf software package. A multi-criteria operation strategy for VPP is presented in [107] applied for the power-to-heat system. It consists of wind, solar, CHP, EV and other electric storage system. The strategy addresses a stochastic optimization algorithm with MILP to eliminate uncertainties and bottom-up modeling to provide optimal scheduling. A novel optimal scheduling model is presented in [108] that considers the battery degradation cost and consists of DERs and ESSs. The method introduces two-stage stochastic mixed-integer linear programming to maximize the expected profit. An optimization algorithm is presented in [37] that focuses on designing an optimal large-scale VPP consisting of several small scale elements in a large area and storage capacity. The proposed algorithm concerns the optimal thermal and electrical energy distribution in the electricity markets and observes each distributed energy resource's exact position (DER). The algorithm deals with the complex problem and addresses mixed integer linear programming to solve the problem in a short computational time and to ensure the maximum profit from the VPP.

A direct load control model for VPP optimization based on linear programming is represented in [109] that is applicable for both distribution and transmission networks. The model involves several DERs for the optimal design of VPP. The model ensures optimal load reduction over a defined control period by computing the optimal control schedule. The proposed control model is practically applied to the Spanish deviation management market to justify its acceptance. The demand-side management (DSM) program for VPP architecture in the urban energy system is presented in [110]. In Figure 14, a DSM representation for a virtual power plant is shown. 


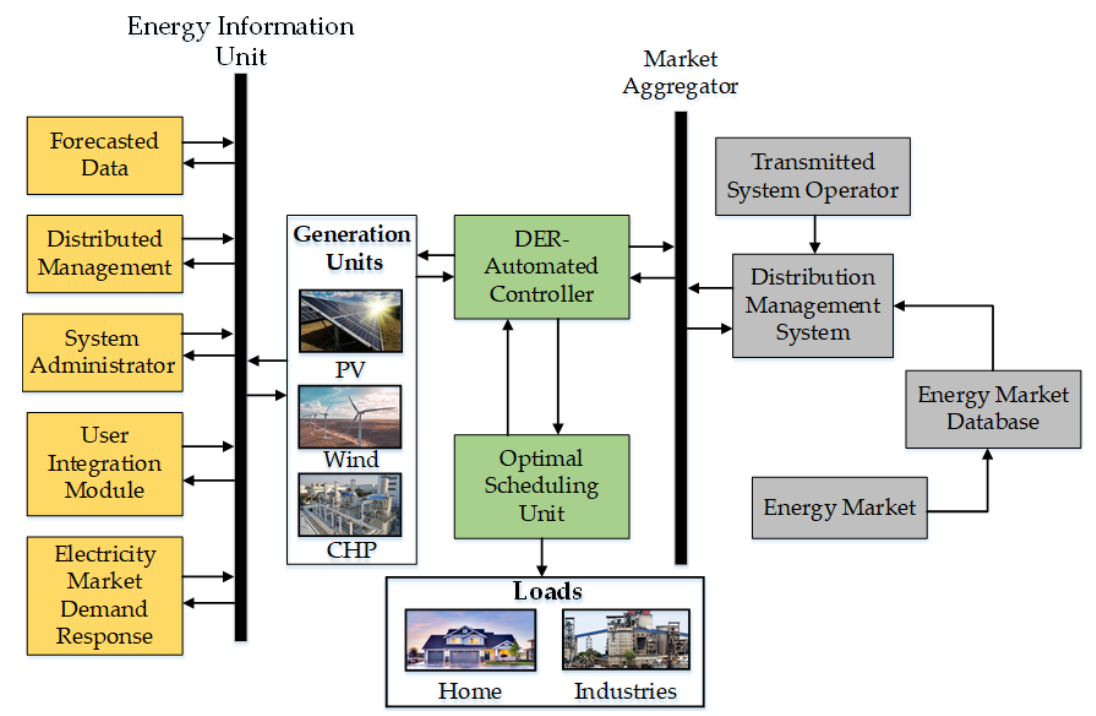

Figure 14. A schematic representation of virtual power plants considering the demand side management or operational scheduling of loads. (Note: PV-photovoltaics; DER-distributed energy resources; CHP-combined heat and power).

It introduces a service-oriented approach to ensure optimal and flexible power distribution among DERs based on-demand responses (DR) such as price-based DR, reduction bias DR, incentive-based DR, and event-based DR. The EMS includes two units: profile generation unit (PGU) and optimal scheduling unit (OSU). It introduces MILP to deal with system complexity and focuses on maximizing profits.

An optimal dispatch scheduling is presented in [111] that focuses on optimal operation VPPs, consisting of RES and CPP. The scheme introduces MILP to solve the optimization problem and ensure maximum profits.

The objective function to minimize operation cost can be illustrated as:

$$
\operatorname{Cost}_{\min }=\sum_{t=1}^{T}\left(C_{\text {conv }}(t)+y_{\text {conv }}(t) * S_{\text {conv }}\right)
$$

where $C_{\text {conv }}(t)$ is the function of the cost of electricity production from CPP, $y_{\text {conv }}(t)$ is 1 when CPP is started from the beginning period $t$ and is 0 in other cases, $S_{\text {conv }}$ is the startup cost of CHP.

An optimization algorithm for VPP is presented in ref. [57], consisting of three different approaches: reference scenario, forced strategy, and economic strategy. The reference scenario only deals with the imbalance error in the electricity market, whereas forced strategy eliminates imbalance error expect considering prices. Financial strategy concerns about maximizing profits with minimum costing. The algorithm includes MILP to solve the DA optimization problem. A VPP control system is demonstrated in [112], consisting of wind, solar, fuel cell, and battery storage. It aims to continue the generation and distribution of energy with maximum profit and minimum cost. MILP with genetic algebraic modeling systems (GAMS) is introduced to implement the system, and Budapest Tech acts as a testing platform. The total minimal marginal cost can be expressed as follows:

$$
\operatorname{Cost}_{\text {Min }}=\sum_{t=1}^{24}\left(\begin{array}{c}
P_{\text {wind }(t)} \times C_{\text {wind }(t)}+P_{P V} \times C_{P V(t)} \\
+P_{F C(t)} \times C_{F C(t)} \\
-P_{\text {Storage Battery Charge }(t)} \times C_{\text {Storage Battery Charge }(t)} \\
+P_{\text {Storage Battery Discharge }(t)} \times C_{\text {Storage Battery Discharge }(t)} \\
+ \text { Undelivered Energy }(t) \times C_{\text {Undelivered Energy }(t)} \\
- \text { Excess Generated Energy }(t) \times C_{\text {Excess Generated Energy }(t)}
\end{array}\right)
$$


Wille-Haussmann et al. [44] proposes a VPP control algorithm based on the MILP technique and tests the acceptability by introducing combined heat and power (CHP) with the DERs. The maximum profits from the proposed scheme can be represented as:

$$
\text { Profit } t_{\max }=\sum_{t=1}^{T}\left[G_{t h}[t]+G_{E E X}[t]-C_{c h p}[t]-C_{b o i l e r}[t]\right]
$$

where $G_{t h}$ and $G_{E E X}$ represent the earnings from selling thermal energy and electrical energy, respectively. $C_{c h p}$, and $C_{\text {boiler }}$ represents the fuel and operational cost of CHP and boiler, respectively.

Among the existing several optimization strategies of VPP, the fifteen optimization techniques are considered in linear algorithm-based optimization techniques, and they are compared in Table 6. It is seen that most of the linear algorithm-based optimization uses MILP (like optimal bidding strategy) and off-self software to curb the complex problem, able to handle the risk as a risk management tool. It can deal with uncertainties by using stochastic optimization.

Table 6. A comparative analysis among different linear programming-based strategies for the virtual power plants.

\begin{tabular}{|c|c|c|c|}
\hline Ref & Optimization Approach & System Configuration & Key Features \\
\hline$[37]$ & $\begin{array}{l}\text { Mixed-integer linear } \\
\text { programming (MILP) } \\
\text { based optimization } \\
\text { algorithm }\end{array}$ & $\begin{array}{l}\text { DER, ESS, and CHP } \\
\text { plant }\end{array}$ & $\begin{array}{l}\text { Provides a reliable platform for the } \\
\text { thermal and electric power } \\
\text { distribution to the electricity market } \\
\text { - Focuses on minimizing the production } \\
\text { and distribution cost } \\
\text { - Introduces MILP to solve problems } \\
\text { with less computational time }\end{array}$ \\
\hline$[44]$ & $\begin{array}{l}\text { An optimization } \\
\text { algorithm }\end{array}$ & CHP system & $\begin{array}{l}\text { - Optimization in power distribution } \\
\text { - } \quad \text { Introduces MILP to maintain } \\
\text { optimal operation }\end{array}$ \\
\hline$[57]$ & $\begin{array}{l}\text { Combined optimization } \\
\text { algorithm }\end{array}$ & $\begin{array}{l}\text { Micro CHP system and } \\
\text { PV power plant }\end{array}$ & $\begin{array}{l}\text { - } \quad \text { Three optimization approaches: } \\
\text { reference scenario, forced strategy, and } \\
\text { economic strategy } \\
\text { - } \quad \text { MILP for problem-solving } \\
\text { - } \quad \text { Ensures low cost with high profits }\end{array}$ \\
\hline [59] & $\begin{array}{l}\text { An agent-based } \\
\text { approach for VPP based } \\
\text { on linear programming }\end{array}$ & $\begin{array}{l}\text { Wind power generator } \\
\text { and electric storage } \\
\text { system (battery) }\end{array}$ & $\begin{array}{l}\text { - } \quad \text { Presents an optimal power } \\
\text { distribution system } \\
\text { - } \quad \text { Maximizes system profits }\end{array}$ \\
\hline [102] & $\begin{array}{l}\text { Mixed-integer linear } \\
\text { programming (MILP) } \\
\text { optimization method }\end{array}$ & RER, ESS, and CPP & $\begin{array}{l}\text { - Considers long-term bilateral with } \\
\text { market responses and uncertainties } \\
\text { Provides an optimal power } \\
\text { management system with } \\
\text { maximum profits }\end{array}$ \\
\hline [103] & $\begin{array}{l}\text { Two-stage stochastic } \\
\text { mixed-integer linear } \\
\text { programming based } \\
\text { optimization algorithm }\end{array}$ & $\begin{array}{l}\text { DER (PV, wind firms, } \\
\text { micro-turbine, diesel } \\
\text { generator, and battery } \\
\text { banks) }\end{array}$ & $\begin{array}{l}\text { - } \quad \text { Considers risk factors } \\
\text { - } \quad \text { The Conditioning Value at Risk acts as } \\
\text { a risk measurement tool } \\
\text { - Maximizes profits and optimizes } \\
\text { risk level }\end{array}$ \\
\hline
\end{tabular}


Table 6. Cont.

\begin{tabular}{|c|c|c|c|}
\hline Ref & Optimization Approach & System Configuration & Key Features \\
\hline [104] & $\begin{array}{l}\text { Two risk management } \\
\text { approach based } \\
\text { interactive cooperation } \\
\text { model }\end{array}$ & DER & $\begin{array}{l}\text { - Considers inter-regional contracts to } \\
\text { design an optimal model } \\
\text { Two risk management approaches: the } \\
\text { conditional value at risk (CVaR) and } \\
\text { second-order stochastic } \\
\text { dominance constraints } \\
\text { - Introduces MILP to solve } \\
\text { complex problems } \\
\text { - Maximizes system efficiency }\end{array}$ \\
\hline [105] & $\begin{array}{l}\text { Coordinated control } \\
\text { strategy }\end{array}$ & $\begin{array}{l}\text { PV and controllable } \\
\text { loads }\end{array}$ & $\begin{array}{l}\text { - } \quad \begin{array}{l}\text { An optimal power } \\
\text { distribution platform }\end{array} \\
\text { Introduces mixed integer } \\
\text { programming (MIP) to solve } \\
\text { coordinated problems } \\
\text { - } \quad \text { DIgSILENT as simulation software }\end{array}$ \\
\hline [106] & $\begin{array}{l}\text { A risk hedging strategy } \\
\text { for commercial VPP }\end{array}$ & DER & $\begin{array}{l}\text { - Considers cross-regional contracts, } \\
\text { bilateral contracts, and energy market } \\
\text { Introduces first-order stochastic } \\
\text { dominance constraints to deal } \\
\text { with uncertainties } \\
\text { - MILP and off-the-shelf software } \\
\text { are used. } \\
\text { A medium-term energy market and } \\
\text { risk management scheme }\end{array}$ \\
\hline [107] & $\begin{array}{l}\text { Multi-criteria operation } \\
\text { strategy }\end{array}$ & $\begin{array}{l}\text { Wind, solar, } \mathrm{CHP}, \mathrm{EV} \text {, } \\
\text { and other electric storage } \\
\text { systems }\end{array}$ & $\begin{array}{l}\text { Ensures optimal power-sharing } \\
\text { platform from sources } \\
\text { - } \quad \text { Considers technical and economic } \\
\text { aspects and uncertainties } \\
\text { - } \quad \text { Bottom-up modeling for } \\
\text { optimal scheduling } \\
\text { - Stochastic optimization and MILP to } \\
\text { eliminate uncertainties }\end{array}$ \\
\hline [108] & $\begin{array}{l}\text { A novel optimal } \\
\text { scheduling model based } \\
\text { on two-stage stochastic } \\
\text { mixed-integer linear } \\
\text { programming }\end{array}$ & DER and ESS & $\begin{array}{l}\text { - Maximizing expected profit through } \\
\text { two-stage stochastic MLIP technique } \\
\text { Considers battery degradation cost } \\
\text { and risk level }\end{array}$ \\
\hline [109] & $\begin{array}{l}\text { Direct load control } \\
\text { model based on linear } \\
\text { programming }\end{array}$ & DER & $\begin{array}{l}\text { - Intends to control the loads in the } \\
\text { electricity market optimally } \\
\text { Controls the thermal behavior of the } \\
\text { space-heating system and } \\
\text { air-conditioning system } \\
\text { - } \quad \text { EnergyPlus software acts as a } \\
\text { simulation tool } \\
\text { - Tested and verified in northern Spain }\end{array}$ \\
\hline
\end{tabular}


Table 6. Cont.

\begin{tabular}{|c|c|c|c|}
\hline Ref & Optimization Approach & System Configuration & Key Features \\
\hline [110] & $\begin{array}{l}\text { Demand-side } \\
\text { management (DSM) } \\
\text { program }\end{array}$ & DER, ESS & $\begin{array}{l}\text { - Introduces the } \\
\text { service-oriented approach } \\
\text { - Emphasizes on-demand responses } \\
\text { (DR) } \\
\text { - Demand responses (DR): price-based } \\
\text { DR, reduction bias-based, } \\
\text { incentive-based and event-based } \\
\text { - Focuses on optimal operation } \\
\text { - } \quad \text { Addresses MILP for system } \\
\text { optimization modeling } \\
\text { Three classifications: physical agents, } \\
\text { communication agents, and } \\
\text { logical agents }\end{array}$ \\
\hline [111] & $\begin{array}{l}\text { Optimal dispatch } \\
\text { scheduling }\end{array}$ & RES and CPP & $\begin{array}{ll}\text { - } & \text { Maximizes profits } \\
\text { - } & \text { Introduces MILP to solve } \\
\text { optimization problems }\end{array}$ \\
\hline [112] & A VPP model & $\begin{array}{l}\text { Wind, solar, fuel cell, and } \\
\text { battery storage }\end{array}$ & $\begin{array}{ll}\text { - } & \text { Optimal operation } \\
\text { - } & \text { Minimization of cost } \\
\text { - } & \text { Maximum profits } \\
\text { - } & \text { MILF with Genetic Algebraic } \\
& \text { Modeling Systems }\end{array}$ \\
\hline
\end{tabular}

Note: DER-distributed energy resources; ESS-energy storage system; CHP-combined heat and power; PV-photovoltaics; VPP-virtual power plant; RER-renewable energy resources; EV-electric vehicle).

\subsection{Optimization Algorithm Based on Stochastic Technique}

The ref. [113] introduces an optimization scheme based on two-stage stochastic programming. This scheme considers two uncertainty parameters: wind power generation and day-ahead market prices and addresses hydro-power storage as an alternative to wind energy. A novel stochastic programming approach is introduced in [114] that uses the Nucleolus and Shapley value methods, a cooperative game theory, to optimize system efficiency with maximum profit. This approach analyzes the day-ahead market (DAM) and the balancing market (BM) for optimal operation. The conditional value at risk $(\mathrm{CVaR})$ is computed to examine the risk factor.

The objective function that maximizes the profit can be expressed as:

$$
\text { Profit }_{\max }=(1-\beta) \sum_{\omega} \sum_{t} \pi_{\omega} \Pi_{t \omega}+\beta\left(\eta-\frac{1}{1-\alpha} \sum_{\omega} \pi_{\omega} \zeta_{\omega}\right)
$$

where $\alpha$ is the setting confident level, $\beta$ is the weighting factor, $\zeta_{\omega}$ is the auxiliary variable to compute $\mathrm{CaVR}, \pi_{\omega}$ is the probability of occurrence of scenario $\omega$, and $\Pi_{t \omega}$ is the profit realized in time $t$ and scenario $\omega$.

In Figure 15, the classification of various best demand response load (DRL) strategies for the stochastic profit-based scheduling approach is presented. A bi-level stochastic scheduling optimization model is proposed in [115] (as shown in Figure 16), which consists of PV, wind, conventional gas turbine (CGT), and energy storage system and introduces robust optimization to eliminate uncertainties. It is a bi-level optimization model where a joint scheduling optimization model is applied to maximize profit at the upper level. Another model is applied at a lower level to minimize system costs. A stochastic adaptive robust optimization scheme for offering strategy is presented in [39]. The strategy deals with 
DA and RT energy market prices to maximize expected profits and eliminates uncertainties from the energy market and wind power generation. The approach considers the level of robustness to ensure the optimal operation DERs with minimum cost.

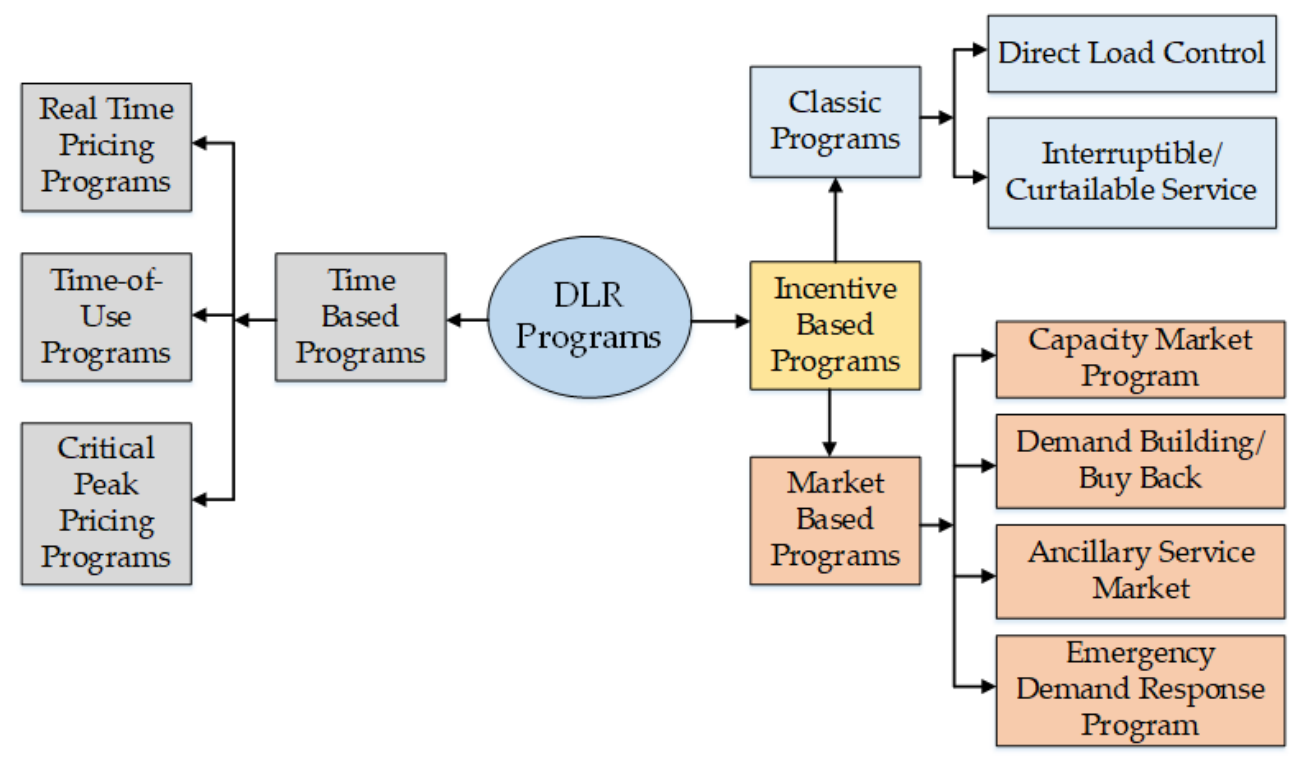

Figure 15. Classification of various best demand response load (DRL) strategies for stochastic profit-based scheduling approach in virtual power plants (Redrawn with permission from [48], 2016, Elsevier).

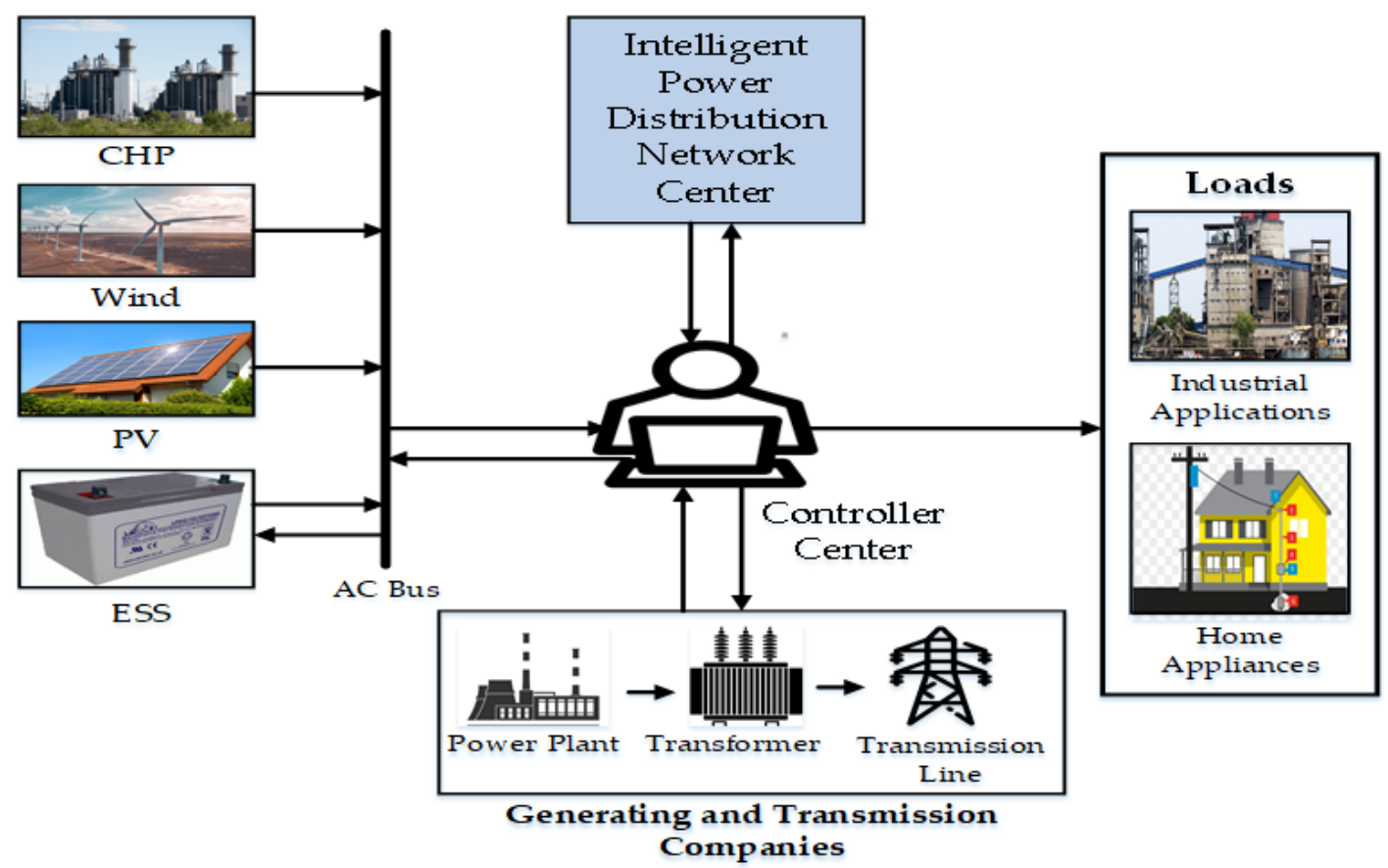

Figure 16. A bi-level stochastic scheduling optimization model for a virtual power plant (Redrawn with permission from [115], 2016, Elsevier).

Another stochastic and deterministic model for VPP is demonstrated in [116] that deals with the secure integration of different RESs. This scheme is evaluated in the European Power Exchange (EPEX)/ European Energy Exchange (EEX). The system considers various aspects: power availability, energy market condition, size of VPP, and marginal cost to maintain optimal operation at low cost. A multi-objective stochastic scheduling optimization model for VPP is proposed in [66] that consists of 
$\mathrm{PV}$, wind, $\mathrm{CPP}$, and EV and considers uncertainties and demand responses of the electricity market, as shown in Figure 17. Stochastic chance constraints planning (SCCP) is introduced to eliminate the uncertainties, and a stochastic scheduling model is proposed to lessen the operational costs and maximize profits. A three-stage hybrid intelligent solution algorithm is addressed that includes: the PSO, the entropy weight method, and the fuzzy satisfaction theory. A stochastic profit-based scheduling approach is also proposed in [48] that emphasizes optimal power scheduling and management in industrial applications of VPP (IVPP).

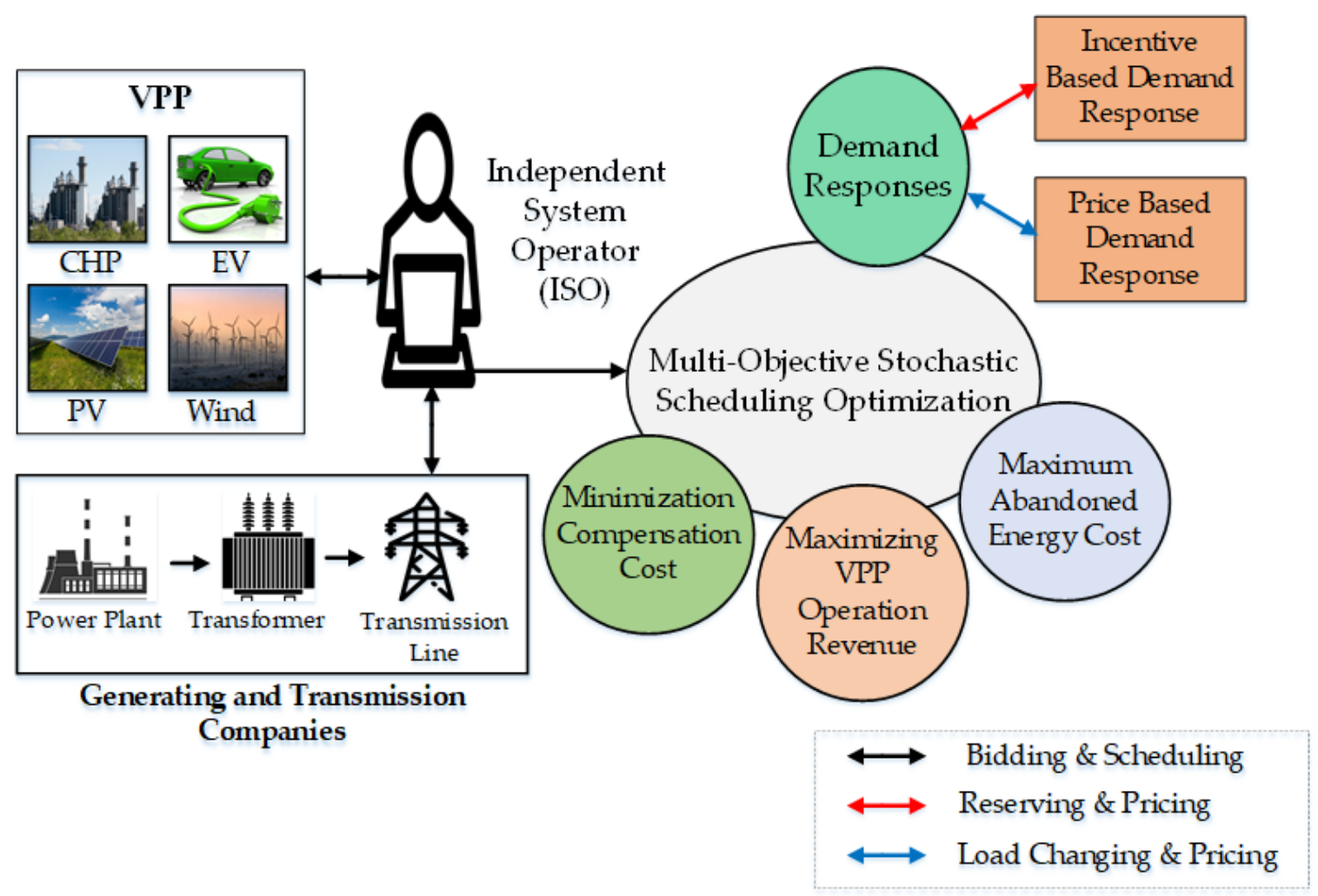

Figure 17. A multi-objective stochastic scheduling optimization model for virtual power plants (Redrawn with permission from [66], 2016, Elsevier) (Note: VPP-virtual power plants; CHP-combined heat and power; EV-electric vehicle; PV-photovoltaics).

The scheme introduces the demand response loads (DRL) programs classified and presented in Figure 15 to fulfill system objectives: maximizing profits and minimizing load shedding. Mixed-integer non-linear programming (MINLP) is applied to deal with an optimization problem. The proposed system is tested in the IEEE reliability test system (IEEE-RTS) that supports its efficacy.

A probabilistic model based on stochastic scheduling for VPP is introduced in [117] that comprises thermal and electrical resources and addresses a modified scenario-based decision-making method to ensure optimal day-ahead scheduling to eliminate uncertainties. To deal with demand response, the model addresses energy and reverse scheduling method.

The maximum profit from the proposed scheme can be calculated as follows:

$$
\begin{aligned}
& \text { Profit } \max _{\max }=\sum_{t=1}^{24} \sum_{s=1}^{N_{s}} \pi_{s} \\
& *\left(\rho_{E M, t} * P_{\text {linets }}^{N_{z}}+\rho_{S R, t s} * P_{S R, t s}+\sum_{z=1}^{N_{z}}\left(-\left(\rho_{d r p, t}^{I} * P_{d r p, z t s}^{I}+\rho_{d r p, t}^{I I} * P_{d r p, z t s}^{I I}+\rho_{d r p, t}^{I I I} * P_{d r p, z t s}^{I I I}+\rho_{e n s, t} * P_{e n s, z t s}\right)+P_{s e l, z t s} * \rho_{r e t p p p, t}\right)\right)
\end{aligned}
$$

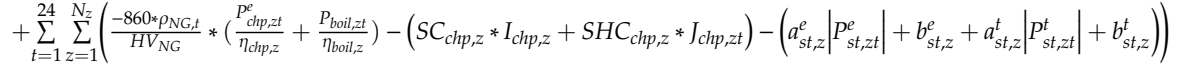

where $P_{S R, t s}$ is the exchange power between VPP and spinning reserve market at hour $t$ and scenario s. $P_{s e l, z t s}$ is the served electric load power at time $t$, zone $z$, and scenario s. $P_{d r p, z t s^{\prime}}^{I} P_{d r p, z t s}^{I I}$ andP $P_{d r p, z t s}^{I I}$ 
represents the first, second, and third-level electric load curtailment respectively of DR at hour $t$, zone $z$, and scenarios s. $P_{\text {ens,zts }}$ is the amount of unserved energy in zone $z$, hour $t$, and scenario s. $P_{\text {line,zt }}$ is the cross power of upstream line at zone $z$ and hour $t . \rho_{S R, t s}$ and $\rho_{E M, t s}$ is the spinning reserve market price and energy market price at hour $t$ and scenario $s$, respectively. $H V_{N G}$ is the heating value of natural gas. $a_{s t, z^{\prime}}^{e}$ and $b_{s t, z}^{e}$ are the positive coefficient of the thermal storage cost function in zone $z$. $\eta_{b o i l, z}$ and $\eta_{c h p, z}$ are the boiler efficiency and CHP electrical efficiency in zone $z$, respectively.

The existing stochastic based strategies may be bi-level or two-stages based. However, both the stochastic techniques can eliminate the uncertainties and maximizes the profit. The discussed eleven different stochastic methods are compared in Table 7, which illustrates that most of the stochastic methods are concerned with the techno-economic optimal scheduling, uses different approaches like Nucleolus and Shapely value, DRL programs to maximizes the profit, and also handle the complex problem and demand response like other approaches.

Table 7. A comparative analysis among different stochastic techniques for the virtual power plants.

\begin{tabular}{|c|c|c|c|}
\hline Ref & Optimization Approach & $\begin{array}{l}\text { System } \\
\text { Configuration }\end{array}$ & Key Features \\
\hline [39] & $\begin{array}{l}\text { Stochastic adaptive } \\
\text { robust optimization } \\
\text { scheme for } \\
\text { offering strategy }\end{array}$ & DER, ESS & $\begin{array}{l}\text { - } \text { Concerns about DA and RT for energy } \\
\text { - } \quad \text { Market prices } \\
\text { - } \\
\text { - } \\
\text { Eliminizes profits and minimizes cost } \\
\text { VPP moderting robust optimization for }\end{array}$ \\
\hline$[48]$ & $\begin{array}{l}\text { The stochastic } \\
\text { profit-based } \\
\text { scheduling approach }\end{array}$ & DER & $\begin{array}{l}\text { - Introduces DRL programs for optimal operation } \\
\text { - } \quad \text { IEEE-Reliability Test System as a } \\
\text { validation platform } \\
\text { - } \quad \text { MILP for optimization problem solving }\end{array}$ \\
\hline$[66]$ & $\begin{array}{l}\text { A multi-objective } \\
\text { stochastic scheduling } \\
\text { optimization model }\end{array}$ & $\begin{array}{l}\text { PV power plant, } \\
\text { wind power } \\
\text { plant, CPP, and } \\
\text { EV }\end{array}$ & $\begin{array}{l}\text { - Considers uncertainties and demand responses } \\
\text { (DR) } \\
\text { - } \quad \text { SCCP for eliminating uncertainties } \\
\text { - } \quad \text { A stochastic scheduling model for } \\
\text { optimal operation } \\
\text { - } \quad \text { Maximizes profits and minimizes cost }\end{array}$ \\
\hline [113] & $\begin{array}{l}\text { Two-stage stochastic } \\
\text { programming based } \\
\text { optimization algorithm }\end{array}$ & $\begin{array}{l}\text { Wind energy } \\
\text { and } \\
\text { hydropower } \\
\text { storage }\end{array}$ & $\begin{array}{l}\text { - Uncertainties: Day-ahead market price and } \\
\text { wind power output } \\
\text { - } \quad \text { Eliminates uncertainties and maximizes profits }\end{array}$ \\
\hline [114] & $\begin{array}{l}\text { A novel stochastic } \\
\text { programming approach }\end{array}$ & DER & $\begin{array}{l}\text { - Uncertainties due to the price of electricity, load } \\
\text { consumption, loss of power, and power output } \\
\text { of generation units } \\
\text { - The Nucleolus and the Shapley value methods } \\
\text { to maximize profits } \\
\text { - The conditional value at risk (CVaR) for } \\
\text { risk measurement } \\
\text { Provides optimal power management with } \\
\text { maximum profits }\end{array}$ \\
\hline
\end{tabular}


Table 7. Cont.

\begin{tabular}{|c|c|c|c|}
\hline Ref & Optimization Approach & $\begin{array}{l}\text { System } \\
\text { Configuration }\end{array}$ & Key Features \\
\hline [115] & $\begin{array}{l}\text { A bi-level stochastic } \\
\text { scheduling optimization } \\
\text { model }\end{array}$ & $\begin{array}{l}\text { PV, wind, } \\
\text { conventional } \\
\text { gas turbine } \\
\text { (CGT), and ESS }\end{array}$ & $\begin{array}{l}\text { - A bi-level optimization model } \\
\text { - The upper level maximizes profit while the } \\
\text { lower level minimizes cost } \\
\text { - } \quad \text { Robust optimization eliminates uncertainties }\end{array}$ \\
\hline [116] & $\begin{array}{l}\text { A stochastic and } \\
\text { deterministic model }\end{array}$ & RES & $\begin{array}{ll}\text { - } & \text { Secure power distribution } \\
\text { - } & \text { Implemented in EPEX/EEX } \\
\text { - } & \text { Concerns about techno-economic conditions }\end{array}$ \\
\hline [117] & A probabilistic model & $\begin{array}{l}\text { Thermal and } \\
\text { electrical } \\
\text { resources }\end{array}$ & $\begin{array}{l}\text { A modified scenario-based decision-making } \\
\text { method for optimal operation and to } \\
\text { eliminate uncertainties } \\
\text { Energy and reverse scheduling method for } \\
\text { demand response }\end{array}$ \\
\hline
\end{tabular}

Note: DER-distributed energy resources; ESS-energy storage system; DA-day ahead; RT-realtime; VPP-virtual power plant; DRL-demand response loads; IEEE-institute of electrical and electronics engineering; MILP-mixed-integer linear programming; CPP-conventional power plant; EV-electric vehicle; SCCP- stochastic chance constraints planning; RER-renewable energy resources; EPEX/EEX-European power exchange/European energy exchange).

An optimization scheme for VPP may subsume more than one technique. For example, an offering strategy may employ either a stochastic method or linear programming. A summarization is illustrated in Table 8 , which indicates whether a technique is included in an optimization scheme or not. The 37-optimization scheme has been included in Table 8, although 65 control strategies are considered for presenting an extensive review of the existing control strategies for VPP.

Table 8. A summarization of the optimization scheme that includes different control techniques.

\begin{tabular}{|c|c|c|c|c|c|c|c|}
\hline Ref. & $\begin{array}{l}\text { Optimization } \\
\text { Scheme }\end{array}$ & $\begin{array}{c}\text { Offering } \\
\text { Model }\end{array}$ & $\begin{array}{l}\text { Intelligent } \\
\text { Technique }\end{array}$ & PBUC & $\begin{array}{l}\text { Bidding } \\
\text { Strategy }\end{array}$ & $\begin{array}{c}\text { Linear } \\
\text { Programming }\end{array}$ & $\begin{array}{l}\text { Stochastic } \\
\text { Technique }\end{array}$ \\
\hline [2] & $\begin{array}{l}\text { Probabilistic } \\
\text { PBUC } \\
\text { approach }\end{array}$ & $x$ & $x$ & $\checkmark$ & $x$ & $\checkmark$ & $x$ \\
\hline [37] & $\begin{array}{l}\text { MILP based } \\
\text { optimization } \\
\text { algorithm }\end{array}$ & $x$ & $x$ & $x$ & $x$ & $\checkmark$ & $x$ \\
\hline [39] & $\begin{array}{l}\text { The } \\
\text { stochastic } \\
\text { adaptive } \\
\text { robust } \\
\text { optimization } \\
\text { scheme }\end{array}$ & $\checkmark$ & $x$ & $x$ & $x$ & $x$ & $v$ \\
\hline [41] & PBUC model & $x$ & $x$ & $\checkmark$ & $x$ & $x$ & $x$ \\
\hline [46] & $\begin{array}{l}\text { A } \\
\text { multi-agent } \\
\text { system } \\
\text { (MAS) }\end{array}$ & $x$ & $\checkmark$ & $x$ & $x$ & $x$ & $x$ \\
\hline
\end{tabular}


Table 8. Cont

\begin{tabular}{|c|c|c|c|c|c|c|c|}
\hline Ref. & $\begin{array}{l}\text { Optimization } \\
\text { Scheme }\end{array}$ & $\begin{array}{l}\text { Offering } \\
\text { Model }\end{array}$ & $\begin{array}{l}\text { Intelligent } \\
\text { Technique }\end{array}$ & PBUC & $\begin{array}{l}\text { Bidding } \\
\text { Strategy }\end{array}$ & $\begin{array}{c}\text { Linear } \\
\text { Programming }\end{array}$ & $\begin{array}{l}\text { Stochastic } \\
\text { Technique }\end{array}$ \\
\hline [48] & $\begin{array}{l}\text { The } \\
\text { stochastic } \\
\text { profit-based } \\
\text { scheduling } \\
\text { approach }\end{array}$ & $x$ & $x$ & $x$ & $x$ & $x$ & $\checkmark$ \\
\hline [57] & $\begin{array}{l}\text { Combined } \\
\text { optimization } \\
\text { algorithm }\end{array}$ & $x$ & $x$ & $x$ & $x$ & $\checkmark$ & $x$ \\
\hline [59] & $\begin{array}{l}\text { Agent-based } \\
\text { approach }\end{array}$ & $x$ & $\checkmark$ & $x$ & $x$ & $\checkmark$ & $x$ \\
\hline [63] & $\begin{array}{l}\text { Optimal } \\
\text { bidding } \\
\text { strategy }\end{array}$ & $x$ & $x$ & $\checkmark$ & $V$ & $x$ & $x$ \\
\hline [66] & $\begin{array}{l}\text { Multi-objective } \\
\text { stochastic } \\
\text { scheduling }\end{array}$ & $x$ & $x$ & $x$ & $x$ & $x$ & $\checkmark$ \\
\hline [86] & $\begin{array}{l}\text { Offering } \\
\text { model based } \\
\text { on two-stage } \\
\text { stochastic } \\
\text { programming }\end{array}$ & $\checkmark$ & $\checkmark$ & $x$ & $x$ & $x$ & $\checkmark$ \\
\hline [87] & $\begin{array}{l}\text { Offering } \\
\text { model based } \\
\text { on two-stage } \\
\text { stochastic } \\
\text { MILP } \\
\text { scheme }\end{array}$ & $\checkmark$ & $x$ & $x$ & $x$ & $\checkmark$ & $\checkmark$ \\
\hline [88] & $\begin{array}{l}\text { Offering } \\
\text { optimization } \\
\text { model }\end{array}$ & $\checkmark$ & $x$ & $x$ & $x$ & $x$ & $x$ \\
\hline [89] & $\begin{array}{l}\text { Risk } \\
\text { aversion } \\
\text { model }\end{array}$ & $\checkmark$ & $x$ & $x$ & $x$ & $x$ & $x$ \\
\hline [90] & $\begin{array}{l}\text { Fuzzy } \\
\text { multiple } \\
\text { objective } \\
\text { optimization } \\
\text { algorithms }\end{array}$ & $x$ & $\checkmark$ & $x$ & $x$ & $x$ & $x$ \\
\hline [91] & $\begin{array}{l}\text { Agent-based } \\
\text { control }\end{array}$ & $x$ & $\checkmark$ & $x$ & $x$ & $x$ & $x$ \\
\hline [92] & $\begin{array}{l}\text { Intelligent } \\
\text { Auto-control } \\
\text { System }\end{array}$ & $x$ & $\checkmark$ & $x$ & $x$ & $x$ & $x$ \\
\hline [93] & $\begin{array}{l}\text { A } \\
\text { multi-agent } \\
\text { system } \\
\text { (MAS) }\end{array}$ & $x$ & $\checkmark$ & $x$ & $x$ & $x$ & $x$ \\
\hline [95] & $\begin{array}{l}\text { Optimal } \\
\text { bidding } \\
\text { strategy }\end{array}$ & $x$ & $x$ & $x$ & $\checkmark$ & $\checkmark$ & $x$ \\
\hline
\end{tabular}


Table 8. Cont

\begin{tabular}{|c|c|c|c|c|c|c|c|}
\hline Ref. & $\begin{array}{l}\text { Optimization } \\
\text { Scheme }\end{array}$ & $\begin{array}{c}\text { Offering } \\
\text { Model }\end{array}$ & $\begin{array}{l}\text { Intelligent } \\
\text { Technique }\end{array}$ & PBUC & $\begin{array}{l}\text { Bidding } \\
\text { Strategy }\end{array}$ & $\begin{array}{c}\text { Linear } \\
\text { Programming }\end{array}$ & $\begin{array}{l}\text { Stochastic } \\
\text { Technique }\end{array}$ \\
\hline [96] & $\begin{array}{l}\text { Optimal } \\
\text { bidding } \\
\text { strategy }\end{array}$ & $x$ & $x$ & $x$ & $\checkmark$ & $\checkmark$ & $x$ \\
\hline [97] & $\begin{array}{l}\text { Optimal } \\
\text { bidding } \\
\text { strategy }\end{array}$ & $x$ & $x$ & $x$ & $\checkmark$ & $\checkmark$ & $x$ \\
\hline [100] & $\begin{array}{l}\text { Mathematical } \\
\text { modeling } \\
\text { with Benders } \\
\text { decomposition } \\
\text { technique }\end{array}$ & $x$ & $x$ & $x$ & $\checkmark$ & $x$ & $x$ \\
\hline [101] & $\begin{array}{l}\text { Bi-level } \\
\text { multi-objective } \\
\text { approach }\end{array}$ & $x$ & $x$ & $x$ & $\checkmark$ & $\checkmark$ & $x$ \\
\hline [109] & $\begin{array}{l}\text { Direct load } \\
\text { control }\end{array}$ & $x$ & $x$ & $x$ & $x$ & $\checkmark$ & $x$ \\
\hline [102] & $\begin{array}{l}\text { MILP } \\
\text { optimization } \\
\text { method }\end{array}$ & $x$ & $x$ & $x$ & $x$ & $\checkmark$ & $x$ \\
\hline [103] & $\begin{array}{l}\text { Two-stage } \\
\text { stochastic } \\
\text { MILP based } \\
\text { optimization } \\
\text { algorithm }\end{array}$ & $x$ & $x$ & $x$ & $x$ & $\checkmark$ & $\checkmark$ \\
\hline [104] & $\begin{array}{l}\text { Interactive } \\
\text { cooperation } \\
\text { model }\end{array}$ & $x$ & $x$ & $x$ & $x$ & $\checkmark$ & $\checkmark$ \\
\hline [105] & $\begin{array}{l}\text { Coordinated } \\
\text { control } \\
\text { strategy }\end{array}$ & $x$ & $x$ & $x$ & $x$ & $\checkmark$ & $x$ \\
\hline [106] & $\begin{array}{l}\text { Risk } \\
\text { hedging } \\
\text { strategy }\end{array}$ & $x$ & $x$ & $x$ & $x$ & $\checkmark$ & $\checkmark$ \\
\hline [107] & $\begin{array}{l}\text { Multi-criteria } \\
\text { operation } \\
\text { strategy }\end{array}$ & $x$ & $x$ & $x$ & $x$ & $\boldsymbol{v}$ & $x$ \\
\hline [108] & $\begin{array}{l}\text { A novel } \\
\text { optimal } \\
\text { scheduling } \\
\text { model }\end{array}$ & $x$ & $x$ & $x$ & $x$ & $\checkmark$ & $\checkmark$ \\
\hline [110] & $\begin{array}{l}\text { Demand-side } \\
\text { management } \\
(\mathrm{DSM})\end{array}$ & $x$ & $x$ & $x$ & $x$ & $\checkmark$ & $x$ \\
\hline [111] & $\begin{array}{l}\text { Optimal } \\
\text { dispatch } \\
\text { scheduling }\end{array}$ & $x$ & $x$ & $x$ & $x$ & $\checkmark$ & $x$ \\
\hline [113] & $\begin{array}{l}\text { Two-stage } \\
\text { stochastic } \\
\text { programming }\end{array}$ & $x$ & $x$ & $x$ & $x$ & $x$ & $\checkmark$ \\
\hline
\end{tabular}


Table 8. Cont.

\begin{tabular}{|c|c|c|c|c|c|c|c|}
\hline Ref. & $\begin{array}{l}\text { Optimization } \\
\text { Scheme }\end{array}$ & $\begin{array}{c}\text { Offering } \\
\text { Model }\end{array}$ & $\begin{array}{l}\text { Intelligent } \\
\text { Technique }\end{array}$ & PBUC & $\begin{array}{l}\text { Bidding } \\
\text { Strategy }\end{array}$ & $\begin{array}{c}\text { Linear } \\
\text { Programming }\end{array}$ & $\begin{array}{l}\text { Stochastic } \\
\text { Technique }\end{array}$ \\
\hline [114] & $\begin{array}{l}\text { Novel } \\
\text { stochastic } \\
\text { programming } \\
\text { approach }\end{array}$ & $x$ & $x$ & $x$ & $x$ & $x$ & $\checkmark$ \\
\hline [115] & $\begin{array}{l}\text { Bi-level } \\
\text { stochastic } \\
\text { scheduling }\end{array}$ & $x$ & $x$ & $x$ & $x$ & $x$ & $\checkmark$ \\
\hline [116] & $\begin{array}{l}\text { The } \\
\text { stochastic } \\
\text { and } \\
\text { deterministic } \\
\text { model }\end{array}$ & $x$ & $x$ & $x$ & $x$ & $x$ & $\checkmark$ \\
\hline
\end{tabular}

$\boldsymbol{V}$ means the technique is included, and $\boldsymbol{X}$ implies the method is not included in the optimization scheme. Note: PBUC-priced-based unit commitment; MILP-mixed-integer linear programming.

Figure 18 presents a graphical illustration that enumerates the number of published papers in recent years (2013-2019) based on specific techniques (conventional, offering model, intelligent approach, PBUC, bidding strategy, linear programming, and stochastic optimization). Figure 18 includes only 44 papers out of 65 present a smooth graphical representation from 2013 to 2019, and the remaining 18 articles were published in different years, including 2007, 2008, 2010, 2011, and 2012.

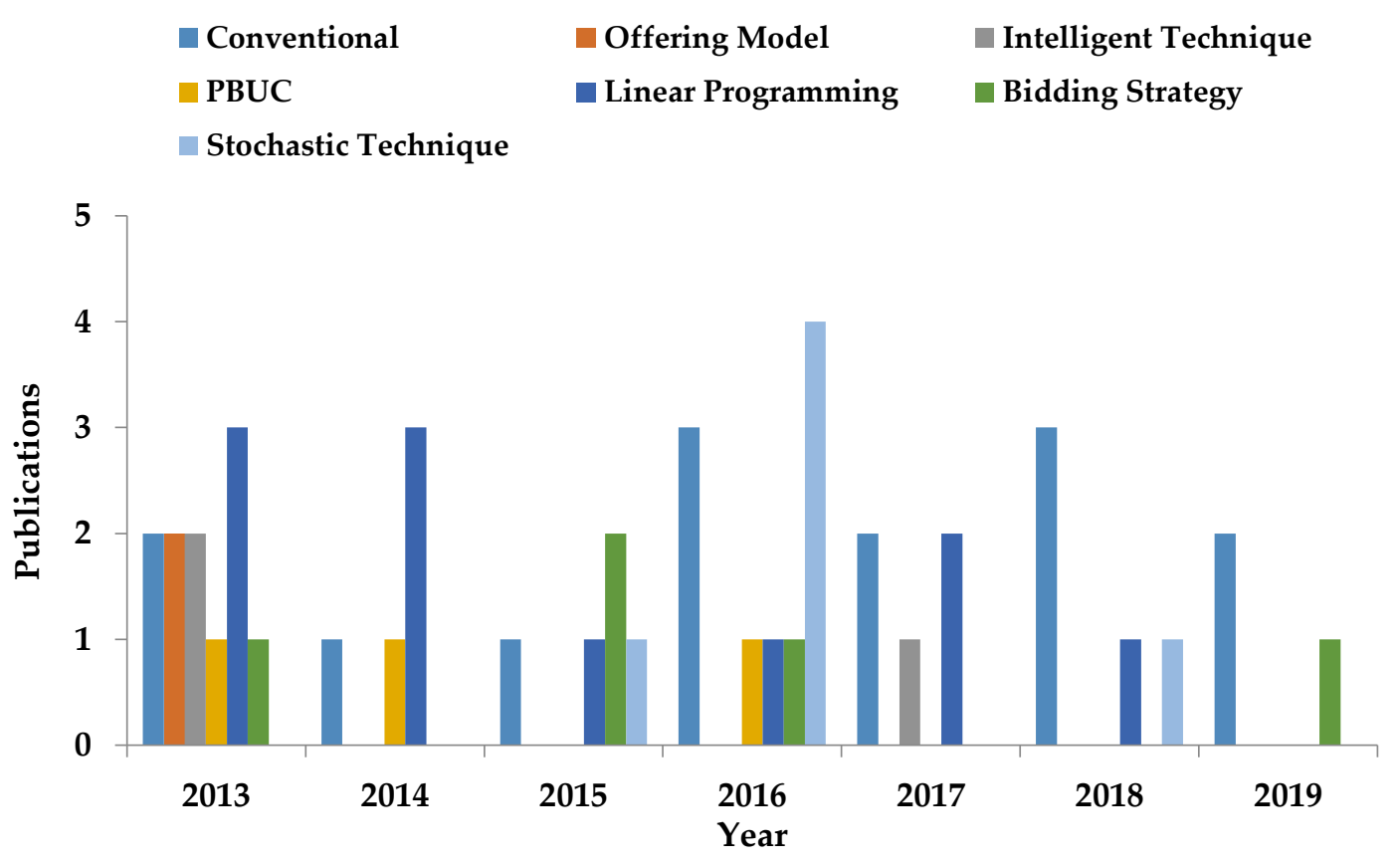

Figure 18. A graphical representation of VPP optimization strategies that are published in different years.

Figure 19 presents a year-based representation of the number of publications in recent years (2013-2019). The highest number of papers was published in 2013, but there was a considerable decrease in publications in the next two years. The number of papers was increased in 2016, and that was 10. The lowest number of papers was published in 2019, and that was three. 


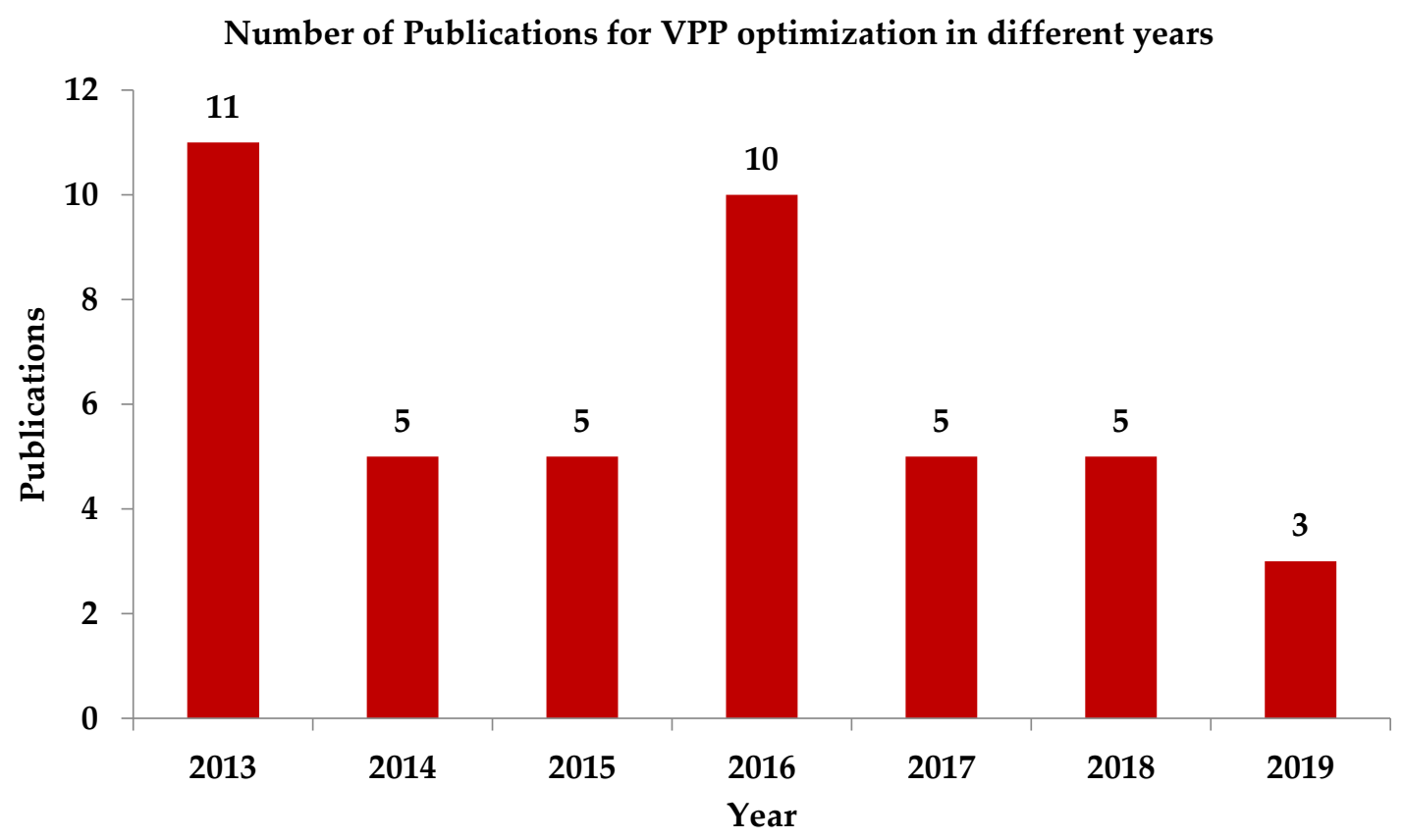

Figure 19. A representation of the total number of publications for VPP optimization scheme in recent years.

\section{Conclusions and Future Directions}

To improve the VPP technology, researchers have proposed several optimization schemes. Selecting a proper optimization scheme from existing methods to apply in a specific VPP field seems quite tricky. Therefore, this paper profoundly analyzes 65 control strategies in terms of optimization techniques, advantages and disadvantages, computational time, economic and technical efficacy, and accuracy. Furthermore, a comparative study is also done among the classified seven types of optimization algorithms, techniques, and methods for VPP that concern the technical and economic efficacy of the system.

The significant findings from the analysis are illustrated as follows:

- The offering strategy that utilizes wind power and demand responses overcomes the intermittence problem in the electricity market. The system also balances the electricity market prices with an improving profit. A fast-computation can be achieved if the offering model is combined with stochastic programming.

- Like fuzzy logic, intelligent control can maintain priority management among suppliers, consumers, and demand responses. Furthermore, a flexible smart grid can be established using MAS that includes ANN, level-based approach, and EVPP.

- PBUC method utilizes DERs in DA market scheduling to handle uncertainties in the electricity market.

- Bidding strategies (BSs) can maximize profits. The BSs with two-stage robust optimization can eliminate uncertainties along with maximizing profits. The security can also be ensured by BDT based BS.

- DLC, based on linear programming, successfully handles both the transmission and distribution system. CCS can govern power in a broader range. Linear programming-based control maximizes profits as well as lessens risk.

- Bi-level or multi-level stochastic optimization can deal with uncertainty parameters such as wind power generation, DA market scheduling, and ultimately provides maximum profits. 
The analysis presents the probability of combining different techniques in a single strategy to attain optimal operation to distribute power in the electricity market. Moreover, the study analyzes different optimization schemes that enable the researchers to verify optimization strategy considering financial and technological reliability, computational time, and eliminating uncertainties. Analysis of the business model provides a notion to handle the electricity market by considering consumers' behavior and demand responses. Optimization strategies that include more than one technique are also analyzed and demonstrated to perceive the feasibility. Overall, the authors believe that the systematic categorization presented in the review work would guide future enthusiasts to choose the proper optimization strategy for a specific application in this field.

VPP provides a flexible platform that can add or remove any of the power sources, but uncertainty results in the system operation. Future research can be extended to analyze uncertainties of VPP. An extensive exploration of day-ahead $24 \mathrm{~h}$ scheduling can be carried out to integrate VPP and power to gas technology. Dynamic load management and priority-based load management in microgrids should be analyzed. There should be comprehensive research to develop the efficacy of the combined operation of VPP and electric vehicle charging. IVPP (information VPP) provides different levels of information to the VPP operator. IVPP should be included in future research to represent the acceptability of the VPP optimization technique. Further research can be considered in the field of inductive charging and autonomous driving.

Author Contributions: Conceptualization, A.K.P. and N.M.K.; data curation, A.K.P., S.I., and N.M.K.; formal analysis, A.K.P., S.I., and N.M.K.; funding acquisition (APC), A.A.C., K.A.P., and K.A.M.; methodology, A.K.P., and N.M.K., resources, N.M.K.; supervision, N.M.K.; visualization, A.K.P., S.I., N.M.K., and A.A.C.; writing—original draft, A.K.P., S.I., and N.M.K.; writing-review \& editing, N.M.K., A.A.C., P.N.R., K.A.P., T.L., and K.A.M. All authors have read and agreed to the published version of the manuscript.

Funding: This research activity received no external funding.

Acknowledgments: This research project is funded by The University of the South Pacific (USP) under the research office Strategic Research Theme (SRT grant-2017); Project Title "Future of Renewable Energy in Fiji". The authors also acknowledge the support from the School of Engineering and Physics at USP.

Conflicts of Interest: The authors declare no conflict of interest.

\section{Abbreviations}

The following abbreviations are used in this manuscript:

$\begin{array}{ll}\text { ABC } & \text { Agent-Based Control } \\ \text { ABP } & \text { Agent-Based Approach } \\ \text { ALDFS } & \text { Adaptive Load Dispatching and Forecasting Strategy } \\ \text { ANN } & \text { Artificial Neural Network } \\ \text { BDT } & \text { Bender Decomposition Technique } \\ \text { BLMOA } & \text { Bi-Level Multi-Objective Approach } \\ \text { BLSSOM } & \text { Bi-Level Stochastic Scheduling Optimization Mode } \\ \text { BM } & \text { Business Model } \\ \text { CCC } & \text { Control Coordination Center } \\ \text { CCS } & \text { Coordinated Control Strategy } \\ \text { CGT } & \text { Conventional Gas Turbine } \\ \text { CHP } & \text { Combined Heat and Power } \\ \text { CIDOA } & \text { Combined Interval and Deterministic Optimization } \\ \text { CPP } & \text { Conventional Power Plant } \\ \text { COA } & \text { Combined Optimization Algorithm } \\ \text { CVaR } & \text { Conditional Value at Risk } \\ \text { DA } & \text { Day-Ahead } \\ \text { DER } & \text { Distributed Energy Resources } \\ \text { DG } & \text { Distributed Generation } \\ \text { DHDCA } & \text { Direct, Hierarchical and Distributed Control Approach }\end{array}$




\begin{tabular}{|c|c|}
\hline DLCM & Direct Load Control Model \\
\hline DSM & Demand Side Management \\
\hline DSO & Distribution System Operator \\
\hline EEX & European Energy Exchange \\
\hline EMM & Energy Management Model \\
\hline EMS & Energy Management System \\
\hline EPEX & European Power Exchange \\
\hline ESS & Energy Storage System \\
\hline EVMM & Electric Vehicle Management Module \\
\hline FC & Fuel Cell \\
\hline FLC & Fuzzy Logic Control \\
\hline FMOOA & Fuzzy Multiple Objective Optimization Algorithm \\
\hline FRS & Frequency Regulation Strategy \\
\hline FSD & First-Order Stochastic Dominance \\
\hline GDCS & Generation Driver Control Strategy \\
\hline IAS & Intelligent Autocontrol System \\
\hline IM & Instant Messaging \\
\hline IOE & Internet of Energy \\
\hline IVPP & Industrial Virtual Power Plant \\
\hline KKT & Karush-Kuhn-Tucker \\
\hline LWC & Levelized Fresh Water Cost \\
\hline MAS & Multi-Agent System \\
\hline MBM & Market-Based Model \\
\hline MCOS & Multi-Criteria Operation Strategy \\
\hline MILP & Mixed Integer Linear Programming \\
\hline MM & Mathematical Model \\
\hline MORSM & Multi-Objective Robust Stochastic Model \\
\hline MOSS & Multi-Objective Stochastic Scheduling \\
\hline MRTS & Mixed Rental Treading Strategy \\
\hline NDRM & Novel Demand Response Model \\
\hline NLMT & Non-Linear Minimization Technique \\
\hline NLMIPM & Non-Linear Mixed Integer Programming Model \\
\hline NOS & Novel Optimal Scheduling \\
\hline NSPA & Novel Stochastic Programming Approach \\
\hline OA & Optimization Algorithm \\
\hline OBS & Optimal Bidding Strategy \\
\hline ODS & Optimal Dispatch Scheduling \\
\hline $\mathrm{OOM}$ & Offering Optimization Model \\
\hline OS & Offering Strategy \\
\hline PBUC & Price-Based Unit Commitment \\
\hline PEM & Point Estimate Model \\
\hline PM & Probabilistic Method \\
\hline PSO & Particle Swarm Optimization \\
\hline PV & Photovoltaic \\
\hline RAM & Risk Aversion Model \\
\hline RES & Renewable Energy Resources \\
\hline RHS & Risk Hedging Strategy \\
\hline RT & Real-Time \\
\hline RTS & Reliability Test System \\
\hline SAEV & Standard Autonomous Electric Vehicle \\
\hline SAROS & Stochastic Adaptive Robust Optimization Scheme \\
\hline SCADA & Supervisory Control and Data Acquisition \\
\hline SDM & Stochastic and Deterministic Model \\
\hline
\end{tabular}




$\begin{array}{ll}\text { SOA } & \text { Service-Oriented Architecture } \\ \text { SPBSA } & \text { Stochastic Profit-Based Scheduling Approach } \\ \text { TPA } & \text { Trip Prediction Algorithm } \\ \text { TRM } & \text { Two Risk Management } \\ \text { TRM } & \text { Two Risk Management } \\ \text { TSO } & \text { Transmission System Operator } \\ \text { TSOSM } & \text { Two-Stage Optimal Scheduling Model } \\ \text { TSSP } & \text { Two-Stage Stochastic Programming } \\ \text { TVPP } & \text { Technical Virtual Power Plant } \\ \text { VOIP } & \text { Voice Over IP }\end{array}$

\section{Nomenclature}

The following nomenclature is used in this manuscript:

\begin{tabular}{|c|c|}
\hline$f$ & The total fuel cost for all the energy resources \\
\hline$C_{\text {Grid }}$ & The cost of electric energy in terms of grid \\
\hline$\eta_{H}$ & Heat generator \\
\hline$\eta_{P}$ & Power generator \\
\hline$\eta_{H c}$ & Combined heat and power plant \\
\hline$T_{\text {tot_cost }}$ & The total cost \\
\hline$A V_{e l}$ & The weighted average of the electricity cost \\
\hline$\beta$ & The deterministic factor \\
\hline$\xi$ & The degree of pessimism of the distribution market \\
\hline$y_{0}$ & The random forecasted values \\
\hline$P^{d}$ & Deterministic profits \\
\hline$L_{t}^{V P P}$ & The total hourly load of VPP \\
\hline$\lambda_{t}^{w}$ & The hourly DA wholesale market prices \\
\hline$U^{-}$ & The total system disutility \\
\hline$\rho_{E M, t^{\prime}}^{f} \rho_{E M, t}^{\omega}$ & The forecasted and scenario-dependent prices in the electricity market, respectively \\
\hline$P_{s e l, z t}^{\omega}$ & The scenario-based electricity demand \\
\hline$P_{s e l, z t}^{s}$ & The scheduled served electricity demand in period $t$ and zone $z$ \\
\hline$\pi_{\omega, t}$ & The probability of occurrence of scenario $\omega$ in period $t$ \\
\hline$\rho_{S R, t}, \rho_{\text {ret }}$ vpp $, t, \rho_{\text {ens }, t}$ & $\begin{array}{l}\text { The spinning reserve market price, VPP's retail energy rate, and considered penalty } \\
\text { of non-reserved in period } t \text { respectively. }\end{array}$ \\
\hline$n_{0}$ & The number of device off \\
\hline$n_{c}$ & The number of devices operating under curtailed power \\
\hline$n_{n}$ & The number of devices operating under normal rated power \\
\hline$C_{u, t}^{E P}$ & The price of earned energy from EP $u$ during period $t$ \\
\hline$C_{t}^{\text {gas }}$ & The price of gasoline during time $t$ \\
\hline$e_{u, t}^{E P}$ & The energy supply by EP $u$ during period $t$ \\
\hline$C S_{v}$ & The average gasoline usage of PHEV \\
\hline$\delta_{v, t}$ & The depth of discharge (DOD) for PHEV $v$ during period $t$ \\
\hline$f(\delta)$ & The probable battery replacement cost as a function of DOD \\
\hline$d_{v, t}^{C S}$ & The charge-sustaining (CS) mode during period $t$ by PHEV $v$ \\
\hline$c(t)$ & The charge energy \\
\hline$C_{\text {bat }}$ & The cost of the battery \\
\hline$L_{\text {bat }}$ & The life of the battery in equivalent full cycle \\
\hline$C_{D G}(t)$ & The cost function of DG \\
\hline$C_{\text {grid }}$ & The cost function of the grid \\
\hline$\gamma_{\text {cycles }}$ & The battery cost during opposite aging \\
\hline$\pi_{r}^{\text {down }}, \pi_{r}^{u p}$ & $\begin{array}{l}\text { The probability of the } r^{\text {th }} \text { down-regulation and up-regulation price } \\
\text { scenario, respectively }\end{array}$ \\
\hline$\psi_{r}^{\text {down }}, \psi_{r}^{u p}$ & The down-regulation and up-regulation price ratio in time $t$ respectively \\
\hline
\end{tabular}




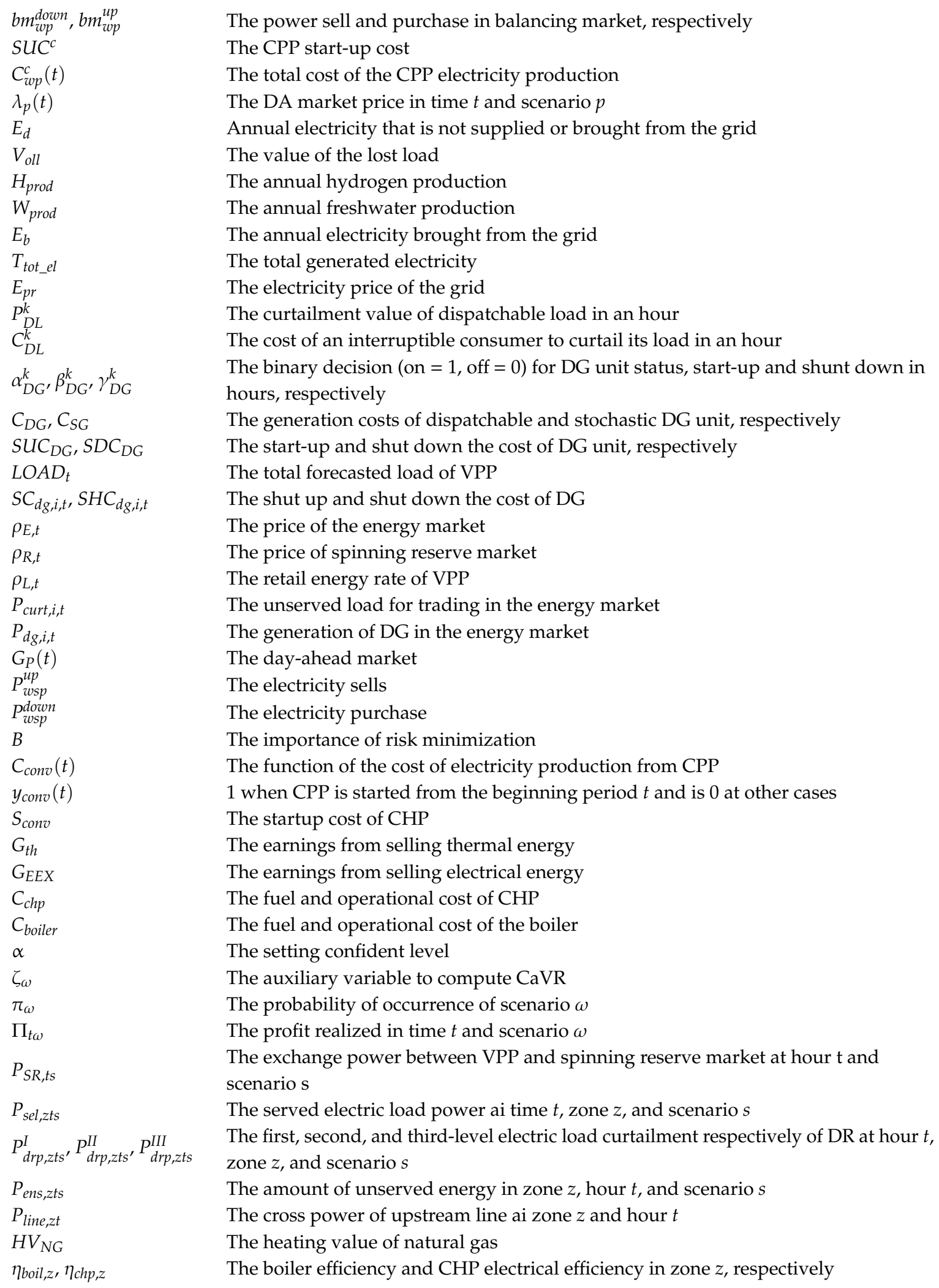

\section{References}

1. Pudjianto, D.; Ramsay, C.; Strbac, G. Virtual power plant and system integration of distributed energy resources. IET Renew. Power Gener. 2007, 1, 10-16. [CrossRef] 
2. Peik-Herfeh, M.; Seifi,H.; Sheikh-El-Eslami, M.K. Decision making of a virtual power plant under uncertainties for bidding in a day-ahead market using point estimate method. Int. J. Electr. Power Energy Syst. 2013, 44, 88-98. [CrossRef]

3. Ziogou, C.; Ipsakis, D.; Seferlis, P.; Bezergianni, S.; Papadopoulou, S.; Voutetakis, S. Optimal production of renewable hydrogen-based on an efficient energy management strategy. Energy 2013, 55, 58-67. [CrossRef]

4. Vessey, A. The Virtual Utility: Accounting, Technology \& Competetive Aspects of the Emerging Industry; Awerbuch, S., Preston, A., Eds.; Springer: New York, NY, USA, 1997; pp. 43-55.

5. Jenkins, N. Secretary of the CIRED Working Group No. 4 on Dispersed Generation; Preliminary Report for Discussion at CIRED: Nice, France, 1-4 June 1999.

6. Moradi, M.H.; Abedini, M. A combination of genetic algorithm and particle swarm optimization for optimal DG location and sizing in distribution systems. Int. J. Electr. Power Energy Syst. 2012, 34, 66-74. [CrossRef]

7. Rotaru, F.; Chicco, G.; Grigoras, G.; Cartina, G. Two-stage distributed generation optimal sizing with clustering-based node selection. Int. J. Electr. Power Energy Syst. 2012, 40, 120-129. [CrossRef]

8. Porkar, S.; Poure, P.; Abbaspour-Tehrani-fard, A.; Saadate, S. A novel optimal distribution system planning framework implementing distributed generation in a deregulated electricity market. Electr. Power Syst. Res. 2010, 80, 828-837. [CrossRef]

9. Podder, A.K.; Roy, N.K.; Pota, H.R. MPPT methods for solar PV systems: A critical review based on trcking nature. IET Renew. Power Gener. 2019, 13, 1615-1632. [CrossRef]

10. Houwing, M.; Ajah, A.N.; Heijnen, P.W.; Bouwmans, I.; Herder, P.M. Uncertainties in the design and operation of distributed energy resources: The case of micro-CHP systems. Energy 2008, 33, 1518-1536. [CrossRef]

11. Algarni, A.A.; Bhattacharya, K. Disco operation considering DG units and their goodness factors. IEEE Trans. Power Syst. 2009, 24, 1831-1840. [CrossRef]

12. Keane, A.; Zhou, Q.W.; Bialek, J.; O'Malley, M. Planning and operating non-firm distributed generation. IET Renew. Power Gener. 2009, 3, 455-464. [CrossRef]

13. Dielmann, K.; van der Velden, A. Virtual power plants (VPP)-a new perspective for energy generation? In Proceedings of the 9th International Scientific and Practical Conference of Students, Post-Graduates Modern Techniques and Technologies, Tomsk, Russia, 7-11 April 2003; pp. 18-20.

14. El Bakari, K.; Kling, W.L. Virtual power plants: An answer to increasing distributed generation. In Proceedings of the 2010 IEEE PES Innovative Smart Grid Technologies Conference Europe (ISGT Europe), Gothenberg, Sweden, 11-13 October 2010; pp. 1-6.

15. Loßner, M.; Böttger, D.; Bruckner, T. Economic assessment of virtual power plants in the German energy market-A scenario-based and model-supported analysis. Energy Econ. 2017, 62, 125-138. [CrossRef]

16. Sigrimis, N.; Arvanitis, K.; Pasgianos, G.; Ferentinos, K. Computer integrated management and intelligent control of greenhouses. Environ. Cont. Biol. 2002, 40, 39-53. [CrossRef]

17. Nikonowicz, Ł.B.; Milewski, J. Virtual power plants-general review: Structure, application, and optimization. J. Power Technol. 2012, 92, 135-149.

18. Kolenc, M. Virtual power plant architecture using OpenADR 2.0b for dynamic charging of automated guided vehicles. Int. J. Electr. Power Energy Syst. 2019, 104, 370-382. [CrossRef]

19. Mahmud, K.; Khan, B.; Ravishankar, J.; Ahmadi, A.; Siano, P. An internet of energy framework with distributed energy resources, prosumers, and small-scale virtual power plants: An overview. Renew. Sustain. Energy Rev. 2020, 127, 1-19. [CrossRef]

20. Binding, C. Electric vehicle fleet integration in the Danish EDISON project-a virtual power plant on the island of Bornholm. In Proceedings of the IEEE PES General Meeting, Providence, RI, USA, 25-29 July 2010; pp. 1-8.

21. Cheng, L.; Zhou, X.; Yun, Q.; Tian, L.; Wang, X.; Liu, Z. A Review on Virtual Power Plants Interactive Resource Characteristics and Scheduling Optimization. In Proceedings of the 2019 IEEE 3rd Conference on Energy Internet and Energy System Integration (EI2), Changsha, China, 8-10 November 2019; pp. 514-519.

22. Kieny, C.; Berseneff, B.; Hadjsaid, N.; Besanger, Y.; Maire, J. On the concept and the interest of virtual power plant: Some results from the European project Fenix. In Proceedings of the 2009 IEEE Power \& Energy Society General Meeting, Calgary, AB, Canada, 26-30 July 2009; pp. 1-6.

23. Chung, B.J.; Kim, C.S.; Son, S.-Y. Analysis of the Virtual Power Plant Model Based on the Use of Emergency Generators in South Korea. J. Electr. Eng. Technol. 2016, 11, 38-46. [CrossRef] 
24. Dudek, M.; Ropuszyńska-Surma, E.; Węglarz, M.; Suwała, W.; Łopata, S.; Leszczyński, J. The Virtual Power Plant-A Review Of Business Models. In Proceedings of the E3S Web of Conferences, Krakow, Poland, 19-21 September 2018; pp. 1-6.

25. Schulz, C.; Roder, G.; Kurrat, M. Virtual power plants with combined heat and power micro-units. In Proceedings of the 2005 International Conference on Future Power Systems, Amsterdam, The Netherlands, 18 November 2005; pp. 1-5.

26. Andersen, P.B.; Poulsen, B.; Decker, M.; Træholt, C.; Ostergaard, J. Evaluation of a generic virtual power plant framework using service oriented architecture. In Proceedings of the 2008 IEEE 2nd International Power and Energy Conference, Johor Bahru, Malaysia, 1-3 December 2008; pp. 1212-1217.

27. Sikorski, T. A Case Study on Distributed Energy Resources and Energy-Storage Systems in a Virtual Power Plant Concept: Technical Aspects. Energie 2020, 13, 3086. [CrossRef]

28. Yu, S.; Fang, F.; Liu, Y.; Liu, J. Uncertainties of virtual power plant: Problems and countermeasures. Appl. Energy 2019, 239, 454-470. [CrossRef]

29. Etherden, N.; Vyatkin, V.; Bollen, M.H.J. Virtual Power Plant for Grid Services Using IEC 61850. IEEE Trans. Ind. Inform. 2016, 12, 437-447. [CrossRef]

30. Ghavidel, S.; Li, L.; Aghaei, J.; Yu, T.; Zhu, J. A review on the virtual power plant: Components and operation systems. In Proceedings of the 2016 IEEE International Conference on Power System Technology (POWERCON), Wollongong, NSW, Australia, 28 September-1 October 2016; pp. 1-6.

31. Heo, J.S.; Lee, K.Y. A multi-agent system-based intelligent identification system for power plant control and fault-diagnosis. In Proceedings of the 2006 IEEE Power Engineering Society General Meeting, Montreal, QC, Canada, 18-22 June 2006; pp. 1-6.

32. Roossien, B.; Hommelberg, M.; Warmer, C.; Kok, K.; Turkstra, J.-W. Virtual power plant field experiment using 10 micro-CHP units at consumer premises. In Proceedings of the CIRED Seminar 2008: SmartGrids for Distribution, Frankfurt, Germany, 23-24 June 2008; pp. 1-4.

33. Palizban, O.; Kauhaniemi, K.; Guerrero, J.M. Microgrids in active network management—Part I: Hierarchical control, energy storage, virtual power plants, and market participation. Renew. Sustain. Energy Rev. 2014, 36, 428-439. [CrossRef]

34. Pal, P.; Parvathy, A.; Devabalaji, K. A broad review on optimal operation of Virtual power plant. In Proceedings of the 2019 2nd International Conference on Power and Embedded Drive Control (ICPEDC), Chennai, India, 21-23 August 2019; pp. 400-405.

35. Zhang, G.; Jiang, C.; Wang, X. Comprehensive review on structure and operation of virtual power plant in electrical system. IET Gener. Trans. Distrib. 2019, 13, 145-156. [CrossRef]

36. Shabanzadeh, M.; Sheikh-El-Eslami, M.-K.; Haghifam, M.-R. A medium-term coalition-forming model of heterogeneous DERs for a commercial virtual power plant. Appl. Energy 2016, 169, 663-681. [CrossRef]

37. Giuntoli, M.; Poli, D. Optimized thermal and electrical scheduling of a large scale virtual power plant in the presence of energy storages. IEEE Trans. Smart Grid 2013, 4, 942-955. [CrossRef]

38. Othman, M.M.; Hegazy, Y.; Abdelaziz, A.Y. A Review of virtual power plant definitions, components, framework and optimization. Int. Electr. Eng. J. 2015, 6, 2010-2024.

39. Baringo, A.; Baringo, L. A stochastic adaptive robust optimization approach for the offering strategy of a virtual power plant. IEEE Trans. Power Syst. 2016, 32, 3492-3504. [CrossRef]

40. Arslan, O.; Karasan, O.E. Cost and emission impacts of virtual power plant formation in plug-in hybrid electric vehicle penetrated networks. Energy 2013, 60, 116-124. [CrossRef]

41. Nezamabadi, H.; Nazar, M.S. Arbitrage strategy of virtual power plants in energy, spinning reserve and reactive power markets. IET Gener. Transm. Distrib. 2016, 10, 750-763. [CrossRef]

42. Wang, Y.; Ai, X.; Tan, Z.; Yan, L.; Liu, S. Interactive dispatch modes and bidding strategy of multiple virtual power plants based on demand response and game theory. IEEE Trans. Smart Grid 2015, 7, 510-519. [CrossRef]

43. Cui, H.; Li, F.; Hu, Q.; Bai, L.; Fang, X. Day-ahead coordinated operation of utility-scale electricity and natural gas networks considering demand response based virtual power plants. Appl. Energy 2016, 176, 183-195. [CrossRef]

44. Wille-Haussmann, B.; Erge, T.; Wittwer, C. Decentralised optimisation of cogeneration in virtual power plants. Sol. Energy 2010, 84, 604-611. [CrossRef]

45. Yang, H.; Yi, D.; Zhao, J.; Dong, Z. Distributed optimal dispatch of virtual power plant via limited communication. IEEE Trans. Power Syst. 2013, 28, 3511-3512. [CrossRef] 
46. Hernández, L. A multi-agent system architecture for smart grid management and forecasting of energy demand in virtual power plants. IEEE Commun. Mag. 2013, 51, 106-113. [CrossRef]

47. Zamani, A.G.; Zakariazadeh, A.; Jadid, S. Day-ahead resource scheduling of a renewable energy based virtual power plant. Appl. Energy 2016, 169, 324-340. [CrossRef]

48. Nosratabadi, S.M.; Hooshmand, R.-A.; Gholipour, E. Stochastic profit-based scheduling of industrial virtual power plant using the best demand response strategy. Appl. Energy 2016, 164, 590-606. [CrossRef]

49. Fan, S.; Ai, Q.; Piao, L. Fuzzy day-ahead scheduling of virtual power plant with optimal confidence level. IET Gener. Transm. Distrib. 2016, 10, 205-212. [CrossRef]

50. Dietrich, K.; Latorre, J.M.; Olmos, L.; Ramos, A. Modelling and assessing the impacts of self supply and market-revenue driven Virtual Power Plants. Electr. Power Syst. Res. 2015, 119, 462-470. [CrossRef]

51. Soares, J.; Borges, N.; Lobo, C.; Vale, Z. VPP energy resources management considering emissions: The case of Northern Portugal 2020 to 2050. In Proceedings of the 2015 IEEE Symposium Series on Computational Intelligence, Cape Town, South Africa, 7-10 December 2015; pp. 1259-1266.

52. Cheng, H.; Gao, Y.; Zhang, J.; Li, R.; Liang, H. The power system multi-objective optimization dispatching containing virtual power plant. In Proceedings of the 2014 International Conference on Power System Technology, Chengdu, China, 20-22 October 2014; pp. 3316-3321.

53. Sučić, S.; Dragičević, T.; Capuder, T.; Delimar, M. Economic dispatch of virtual power plants in an event-driven service-oriented framework using standards-based communications. Electr. Power Syst. Res. 2011, 81, 2108-2119. [CrossRef]

54. Lee, D.; Park, D.; Park, J.-B.; Lee, K.-Y. Security-constrained unit commitment considering demand response resource as virtual power plant. IFAC-PapersOnLine 2016, 49, 290-295. [CrossRef]

55. Hossain, M.A.; Pota, H.R.; Squartini, S.; Zaman, F.; Muttaqi, K.M. Energy management of community microgrids considering degradation cost of battery. J. Energy Storage 2019, 22, 257-269. [CrossRef]

56. Petersen, M.K.; Hansen, L.H.; Bendtsen, J.; Edlund, K.; Stoustrup, J. Heuristic optimization for the discrete virtual power plant dispatch problem. IEEE Trans. Smart Grid 2014, 5, 2910-2918. [CrossRef]

57. Zapata, J.; Vandewalle, J.; D'Haeseleer, W. A comparative study of imbalance reduction strategies for virtual power plant operation. Appl. Therm. Eng. 2014, 71, 847-857. [CrossRef]

58. Xiao, J.; Kong, X.; Jin, Q.; You, H.; Cui, K.; Zhang, Y. Demand-responsive Virtual Power Plant optimization scheduling method based on competitive bidding equilibrium. Energy Procedia 2018, 152, 1158-1163. [CrossRef]

59. Vasirani, M.; Kota, R.; Cavalcante, R.L.; Ossowski, S.; Jennings, N.R. An agent-based approach to virtual power plants of wind power generators and electric vehicles. IEEE Trans. Smart Grid 2013, 4, 1314-1322. [CrossRef]

60. Mnatsakanyan, A.W.; Kennedy, S. A Novel Demand Response Model with an Application for a Virtual Power Plant. IEEE Trans. Smart Grid 2015, 6, 230-237. [CrossRef]

61. Wei, C. A bi-level scheduling model for virtual power plants with aggregated thermostatically controlled loads and renewable energy. Appl. Energy 2018, 224, 659-670. [CrossRef]

62. Kumar, K.P.; Saravanan, B.; Swarup, K. A two stage increase-decrease algorithm to optimize distributed generation in a virtual power plant. Energy Procedia 2016, 90, 276-282. [CrossRef]

63. Mashhour, E.; Moghaddas-Tafreshi, S.M. Bidding Strategy of Virtual Power Plant for Participating in Energy and Spinning Reserve Markets-Part I: Problem Formulation. IEEE Trans. Power Syst. 2011, 26, 949-956. [CrossRef]

64. Manoj Kumar, N.; Ghosh, A.; Chopra, S.S. Power Resilience Enhancement of a Residential Electricity User Using Photovoltaics and a Battery Energy Storage System under Uncertainty Conditions. Energies 2020, 13, 4193. [CrossRef]

65. Duan, J. Multi-Objective Virtual Power Plant Construction Model Based on Decision Area Division. Appl. Sci. 2018, 8, 1484. [CrossRef]

66. Ju, L.; Li, H.; Zhao, J.; Chen, K.; Tan, Q.; Tan, Z. Multi-objective stochastic scheduling optimization model for connecting a virtual power plant to wind-photovoltaic-electric vehicles considering uncertainties and demand response. Energy Convers. Manag. 2016, 128, 160-177. [CrossRef]

67. Liu, Y.; Li, M.; Lian, H.; Tang, X.; Liu, C.; Jiang, C. Optimal dispatch of virtual power plant using interval and deterministic combined optimization. Int. J. Electr. Power Energy Syst. 2018, 102, 235-244. [CrossRef] 
68. Caldon, R.; Patria, A.R.; Turri, R. Optimisation algorithm for a virtual power plant operation. In Proceedings of the 39th International Universities Power Engineering Conference (UPEC 2004), Bristol, UK, 6-8 September 2004; Volume 3, pp. 1058-1062.

69. Lombardi, P.; Powalko, M.; Rudion, K. Optimal operation of a virtual power plant. In Proceedings of the 2009 IEEE Power \& Energy Society General Meeting, Calgary, AB, Canada, 26-30 July 2009; pp. 1-6.

70. Tahmasebi, M.; Pasupuleti, J. Self-scheduling of wind power generation with direct load control demand response as a virtual power plant. Indian J. Sci. Techno. 2013, 6, 1-7. [CrossRef]

71. Raab, A.F. Virtual power plant control concepts with electric vehicles. In Proceedings of the 2011 16th International Conference on Intelligent System Applications to Power Systems, Hersonissos, Greece, 25-28 September 2011; pp. 1-6.

72. You, S.; Træholt, C.; Poulsen, B. A market-based virtual power plant. In Proceedings of the 2009 International Conference on Clean Electrical Power, Capri, Italy, 9-11 June 2009; pp. 460-465.

73. Peikherfeh, M.; Seifi, H.; Sheikh-El-Eslami, M.K. Optimal decision making for virtual power plant operation. In Proceedings of the 2010 Conference Proceedings IPEC, Singapore, 27-29 October 2010; pp. 625-629.

74. Salmani, M.A.; Tafreshi, S.M.; Salmani, H. Operation optimization for a virtual power plant. In Proceedings of the 2009 IEEE PES/IAS Conference on Sustainable Alternative Energy (SAE), Valencia, Spain, 28-30 September 2009; pp. 1-6.

75. Tascikaraoglu, A.; Erdinc, O.; Uzunoglu, M.; Karakas, A. An adaptive load dispatching and forecasting strategy for a virtual power plant including renewable energy conversion units. Appl. Energy 2014, 119, 445-453. [CrossRef]

76. Almadhor, A. Intelligent control mechanism in smart micro grid with mesh networks and virtual power plant model. In Proceedings of the 2019 16th IEEE Annual Consumer Communications \& Networking Conference (CCNC), Las Vegas, NV, USA, 11-14 January 2019; pp. 1-6.

77. El Bakari, K.; Kling, W. Fitting distributed generation in future power markets through virtual power plants. In Proceedings of the 2012 9th International Conference on the European Energy Market, Florence, Italy, 10-12 May 2012; pp. 1-7.

78. Iacobucci, R.; McLellan, B.; Tezuka, T. The synergies of shared autonomous electric vehicles with renewable energy in a virtual power plant and microgrid. Energies 2018, 11, 2016. [CrossRef]

79. Jansen, B.; Binding, C.; Sundstrom, O.; Gantenbein, D. Architecture and communication of an electric vehicle virtual power plant. In Proceedings of the 2010 First IEEE International Conference on Smart Grid Communications, Gaithersburg, MD, USA, 4-6 October 2010; pp. 149-154.

80. Ju, L.; Zhao, R.; Tan, Q.; Lu, Y.; Tan, Q.; Wang, W. A multi-objective robust scheduling model and solution algorithm for a novel virtual power plant connected with power-to-gas and gas storage tank considering uncertainty and demand response. Appl. Energy 2019, 250, 1336-1355. [CrossRef]

81. Kahlen, M.T.; Ketter, W.; van Dalen, J. Electric vehicle virtual power plant dilemma: Grid balancing versus customer mobility. Prod. Oper. Manag. 2018, 27, 2054-2070. [CrossRef]

82. Yang, J.; Zheng, Q.; Zhao, J.; Guo, X.; Gao, C. Control strategy of virtual power plant participating in the system frequency regulation service. In Proceedings of the 20174 th International Conference on Systems and Informatics (ICSAI), Hangzhou, China, 11-13 November 2017; pp. 324-328.

83. Qiu, J.; Meng, K.; Zheng, Y.; Dong, Z.Y. Optimal scheduling of distributed energy resources as a virtual power plant in a transactive energy framework. IET Gener. Transm. Distrib. 2017, 11, 3417-3427. [CrossRef]

84. Thavlov, A.; Bindner, H.W. Utilization of Flexible Demand in a Virtual Power Plant Set-Up. IEEE Trans. Smart Grid 2015, 6, 640-647. [CrossRef]

85. Robu, V.; Kota, R.; Chalkiadakis, G.; Rogers, A.; Jennings, N. Cooperative virtual power plant formation using scoring rules. In Proceedings of the Twenty-Sixth AAAI Conference on Artificial Intelligence (AAAI-12), Toronto, AB, Canada, 22 June 2012; pp. 370-376.

86. Moghaddam, I.G.; Nick, M.; Fallahi, F.; Sanei, M.; Mortazavi, S. Risk-averse profit-based optimal operation strategy of a combined wind farm-cascade hydro system in an electricity market. Renew. Energy 2013, 55, 252-259. [CrossRef]

87. Pandžić, H.; Morales, J.M.; Conejo, A.J.; Kuzle, I. Offering model for a virtual power plant based on stochastic programming. Appl. Energy 2013, 105, 282-292. [CrossRef]

88. Mohammadi, J.; Rahimi-Kian, A.; Ghazizadeh, M.S. Aggregated wind power and flexible load offering strategy. IET Renew. Power Gener. 2011, 5, 439-447. [CrossRef] 
89. Pousinho, H.M.I.; Mendes, V.M.F.; da Silva Catalão, J.P. A risk-averse optimization model for trading wind energy in a market environment under uncertainty. Energy 2011, 36, 4935-4942. [CrossRef]

90. Gong, J.; Xie, D.; Jiang, C.; Zhang, Y. Multiple Objective Compromised Method for Power Management in Virtual Power Plants. Energies 2011, 4, 700-716. [CrossRef]

91. Dimeas, A.L.; Hatziargyriou, N.D. Agent based control of virtual power plants. In Proceedings of the 2007 International Conference on Intelligent Systems Applications to Power Systems, Toki Messe, Niigata, Japan, 5-8 November 2007; pp. 1-6.

92. Yousaf, W.; Asghar, E.; Meng, H.; Songyuan, Y.; Fang, F. Intelligent control method of distributed generation for power sharing in virtual power plant. In Proceedings of the 2017 IEEE International Conference on Unmanned Systems (ICUS), Beijing, China, 27-29 October 2017; pp. 576-581.

93. Skarvelis-Kazakos, S.; Rikos, E.; Kolentini, E.; Cipcigan, L.M.; Jenkins, N. Implementing agent-based emissions trading for controlling Virtual Power Plant emissions. Electr. Power Syst. Res. 2013, 102, 1-7. [CrossRef]

94. Peik-herfeh, M.; Seifi, H.; Sheikh-El-Eslami, M.K. Two-stage approach for optimal dispatch of distributed energy resources in distribution networks considering virtual power plant concept. Int. Trans. Electr. Energy Syst. 2014, 24, 43-63. [CrossRef]

95. Kardakos, E.G.; Simoglou, C.K.; Bakirtzis, A.G. Optimal Offering Strategy of a Virtual Power Plant: A Stochastic Bi-Level Approach. IEEE Trans. Smart Grid 2016, 7, 794-806. [CrossRef]

96. Zdrilić, M.; Pandžić, H.; Kuzle, I. The mixed-integer linear optimization model of virtual power plant operation. In Proceedings of the 2011 8th International Conference on the European Energy Market (EEM), Zagreb, Croatia, 25-27 May 2011; pp. 467-471.

97. Riveros, J.Z.; Bruninx, K.; Poncelet, K.; D’haeseleer, W. Bidding strategies for virtual power plants considering CHPs and intermittent renewables. Energy Convers. Manag. 2015, 103, 408-418. [CrossRef]

98. Chaves-Ávila, J.P.; Hakvoort, R.A.; Ramos, A. Short-term strategies for Dutch wind power producers to reduce imbalance costs. Energy Policy 2013, 52, 573-582. [CrossRef]

99. Rahimiyan, M.; Baringo, L. Strategic bidding for a virtual power plant in the day-ahead and real-time markets: A price-taker robust optimization approach. IEEE Trans. Power Syst. 2016, 31, 2676-2687. [CrossRef]

100. Mahdavi, S.; Javidi, M. VPP decision making in power markets using Benders decomposition. Int. Trans. Electr. Energy Syst. 2014, 24, 960-975. [CrossRef]

101. Shafiekhani, M.; Badri, A.; Shafie-Khah, M.; Catalão, J.P. Strategic bidding of virtual power plant in energy markets: A bi-level multi-objective approach. Int. J. Electr. Power Energy Syst. 2019, 113, 208-219. [CrossRef]

102. Pandžić, H.; Kuzle, I.; Capuder, T. Virtual power plant mid-term dispatch optimization. Appl. Energy 2013, 101, 134-141. [CrossRef]

103. Tajeddini, M.A.; Rahimi-Kian, A.; Soroudi, A. Risk averse optimal operation of a virtual power plant using two stage stochastic programming. Energy 2014, 73, 958-967. [CrossRef]

104. Shabanzadeh, M.; Sheikh-El-Eslami, M.-K.; Haghifam, M.-R. An interactive cooperation model for neighboring virtual power plants. Appl. Energy 2017, 200, 273-289. [CrossRef]

105. Liu, Y.; Xin, H.; Gan, D.; Wang, Z. Control of virtual power plant in microgrids: A coordinated approach based on photovoltaic systems and controllable loads. IET Gener. Transm. Distrib. 2015, 9, 921-928. [CrossRef]

106. Shabanzadeh, M.; Sheikh-El-Eslami, M.-K.; Haghifam, M.-R. Risk-based medium-term trading strategy for a virtual power plant with first-order stochastic dominance constraints. IET Gener. Transm. Distrib. 2017, 11, 520-529. [CrossRef]

107. Sowa, T.; Krengel, S.; Koopmann, S.; Nowak, J. Multi-criteria operation strategies of power-to-heat-systems in virtual power plants with a high penetration of renewable energies. Energy Procedia 2014, 46, 237-245. [CrossRef]

108. Zhou, B.; Cao, Y.; Li, C.; Liu, X.; Chung, C.Y.; Chan, K.W. Optimal scheduling of virtual power plant with battery degradation cost. IET Gener. Transm. Distrib. 2016, 10, 712-725. [CrossRef]

109. Ruiz, N.; Cobelo, I.; Oyarzabal, J. A Direct load control model for virtual power plant management. IEEE Trans. Power Syst. 2009, 24, 959-966. [CrossRef]

110. Pasetti, M.; Rinaldi, S.; Manerba, D. A Virtual Power Plant Architecture for the Demand-Side Management of Smart Prosumers. Appl. Sci. 2018, 8, 432. [CrossRef]

111. Kuzle, I.; Zdrilić, M.; Pandžić, H. Virtual power plant dispatch optimization using linear programming. In Proceedings of the 2011 10th International Conference on Environment and Electrical Engineering, Rome, Italy, 8-11 May 2011; pp. 1-4. 
112. Morais, H.; Kádár, P.; Faria, P.; Vale, Z.A.; Khodr, H. Optimal scheduling of a renewable micro-grid in an isolated load area using mixed-integer linear programming. Renew. Energy 2010, 35, 151-156. [CrossRef]

113. Garcia-Gonzalez, J.; de la Muela, R.M.R.; Santos, L.M.; Gonzalez, A.M. Stochastic joint optimization of wind generation and pumped-storage units in an electricity market. IEEE Trans. Power Syst. 2008, 23, 460-468. [CrossRef]

114. Dabbagh, S.R.; Sheikh-El-Eslami, M.K. Risk-based profit allocation to DERs integrated with a virtual power plant using cooperative Game theory. Electr. Power Syst. Res. 2015, 121, 368-378. [CrossRef]

115. Ju, L.; Tan, Z.; Yuan, J.; Tan, Q.; Li, H.; Dong, F. A bi-level stochastic scheduling optimization model for a virtual power plant connected to a wind-photovoltaic-energy storage system considering the uncertainty and demand response. Appl. Energy 2016, 171, 184-199. [CrossRef]

116. Candra, D.; Hartmann, K.; Nelles, M. Economic Optimal Implementation of Virtual Power Plants in the German Power Market. Energies 2018, 11, 2365. [CrossRef]

117. Zamani, A.G.; Zakariazadeh, A.; Jadid, S.; Kazemi, A. Stochastic operational scheduling of distributed energy resources in a large scale virtual power plant. Int. J. Electr. Power Energy Syst. 2016, 82, 608-620. [CrossRef]

Publisher's Note: MDPI stays neutral with regard to jurisdictional claims in published maps and institutional affiliations.

(C) 2020 by the authors. Licensee MDPI, Basel, Switzerland. This article is an open access article distributed under the terms and conditions of the Creative Commons Attribution (CC BY) license (http://creativecommons.org/licenses/by/4.0/). 